Florida International University

FIU Digital Commons

$10-31-2018$

\title{
The Effect of Reciprocal Mapping on Third-Grade Students' Reading Comprehension Achievement and Reading Attitude
}

Olga Elena Flamion

Florida International University, oflam001@fiu.edu

Follow this and additional works at: https://digitalcommons.fiu.edu/etd

Part of the Curriculum and Instruction Commons, and the Language and Literacy Education Commons

\section{Recommended Citation}

Flamion, Olga Elena, "The Effect of Reciprocal Mapping on Third-Grade Students' Reading Comprehension Achievement and Reading Attitude" (2018). FIU Electronic Theses and Dissertations. 3891.

https://digitalcommons.fiu.edu/etd/3891

This work is brought to you for free and open access by the University Graduate School at FIU Digital Commons. It has been accepted for inclusion in FIU Electronic Theses and Dissertations by an authorized administrator of FIU Digital Commons. For more information, please contact dcc@fiu.edu. 


\title{
FLORIDA INTERNATIONAL UNIVERSITY
}

\author{
Miami, Florida
}

THE EFFECT OF RECIPROCAL MAPPING ON THIRD-GRADE STUDENTS' READING COMPREHENSION ACHIEVEMENT AND READING ATTITUDE

A dissertation submitted in partial fulfillment of

the requirements for the degree of

DOCTOR OF PHILOSOPHY

in

CURRICULUM AND INSTRUCTION

by

Olga Elena Flamion 
To: Dean Michael R. Heithaus

College of Arts, Sciences and Education

This dissertation, written by Olga Elena Flamion, and entitled The Effect of Reciprocal Mapping on Third-Grade Students' Reading Comprehension Achievement and Reading Attitude, having been approved in respect to style and intellectual content, is referred to you for judgment.

We have read this thesis and recommend that it be approved.

$\begin{array}{r}\text { Mido Chang } \\ \hline \text { Elizabeth Cramer } \\ \hline \text { George O'Brien } \\ \hline \text { Joyce Fine, Major Professor }\end{array}$

Date of Defense: October 31, 2018

The dissertation of Olga Elena Flamion is approved.

Dean Michael R. Heithaus

College of Arts, Sciences and Education

Andrés G. Gil

Vice President for Research and Economic Development and Dean of the University Graduate School

Florida International University, 2018 
(C) Copyright 2018 by Olga Elena Flamion

All rights reserved. 


\section{DEDICATION}

I dedicate this dissertation to my family. Thank you for supporting me during this process. To my children, Madeleine and William, thank you for bringing endless amount of love and joy to my life. 


\section{ACKNOWLEDGMENTS}

My sincerely gratitude goes to my committee for their guidance. Dr. Joyce Fine, you not only served as my major professor but most importantly, my mentor. You encouraged and guided my research from the inception. I am most grateful for all the doors you have opened for me. You encouraged me to present at conferences and teach as an adjunct professor. When there was a glimpse of fear, your sweet yet prevailing voice put me at ease and catapulted me forward. Many obstacles brought upon many dark days, weeks, and even months, yet my weakest moments were your strongest. Thank you for guiding me towards this next stage in my academic and professional career. Dr. Chang, thank you for your guidance with my research analyses. I appreciate your patience and positivity towards my questions and concerns. Because of your courses, I am able to conduct these analyses with more ease. Dr. Cramer, thank you for your commitment towards my research. I appreciate your time and feedback. I look forward to continue working with you. Dr. O’Brien, I cannot express enough how eternally grateful I am for you to not only agreeing to join the committee but staying with me an extra semester. Your feedback had positive effects on my research. 


\author{
ABSTRACT OF THE DISSERTATION \\ THE EFFECT OF RECIPROCAL MAPPING ON THIRD-GRADE STUDENTS' \\ READING COMPREHENSION ACHIEVEMENT AND READING ATTITUDE \\ by \\ Olga Elena Flamion
}

Florida International University, 2018

Miami, Florida

Professor Joyce Fine, Major Professor

Reading comprehension is the process of simultaneously extracting and constructing meaning through interaction and involvement with written language (Snow, Science and Technology, and States, 2002). For many students, there is a decrease in reading achievement as early as fourth grade as a result of increased demands in complexity of intermediate text (Williams et al., 2005). Reading attitude is "a system of feelings related to reading which causes the learner to approach or avoid a reading situation" (Fishbein \& Ajzen, 1975, p. 1). McKenna, Kear, and Ellsworth (1995) found that attitude towards reading grew increasingly negative as students moved from first to sixth grade. In addition, the Common Core Standards requirement on students to read and write from informational text has made an even greater demand on teachers to improve reading comprehension.

The study aimed to advance the research on the impact of reading strategy instruction towards reading comprehension and reading attitude. Reading strategies are 
deliberate attempts to modify the reader's efforts to construct meaning of text. The current quasi-experimental study investigated the effect of the Reciprocal Mapping (Fine, 2004) approach on third-grade students' reading comprehension achievement and reading attitude. Reciprocal Mapping (Fine, 2004) is an integrated reading/writing strategy, using visual representation to make concrete the process of examining the text structure of science informational text.

The theoretical framework for the proposed study stems from a sociocultural perspective. This perspective incorporates readers' backgrounds while developing their cognitive strategies and metacognitive skills for comprehending text. The investigator developed a pretest/posttest comparison group quasi-experimental design.

The study's independent variable was group membership, with the dependent variables being reading comprehension achievement and reading attitude. An ANCOVA indicated that there was a significant difference for overall reading comprehension between the two groups on the basis of the post reading test scores when controlling for the pre-test scores. However, when analyzing for reading attitude, there was not a significant difference for overall reading attitude. The findings suggest that standardsbased instruction on science informational text with the Reciprocal Mapping (Fine, 2004) approach was an effective method for increasing third-grade students' reading comprehension. 


\section{TABLE OF CONTENTS}

CHAPTER

PAGE

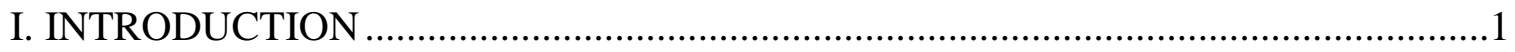

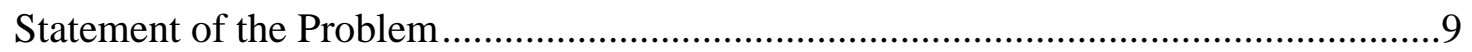

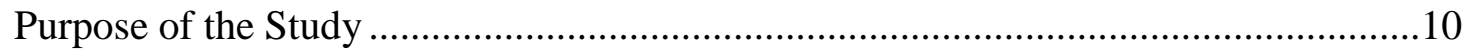

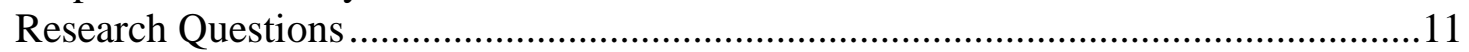

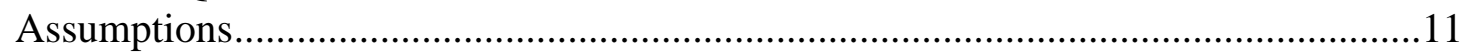

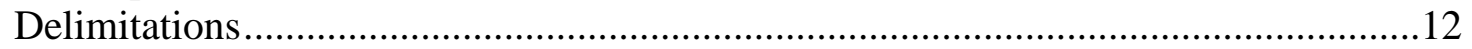

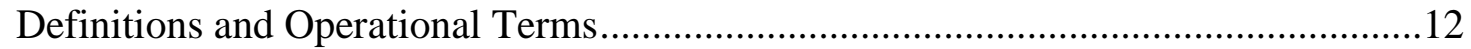

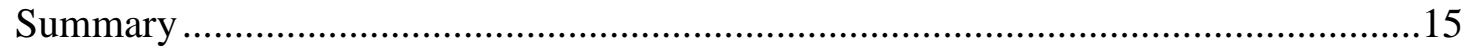

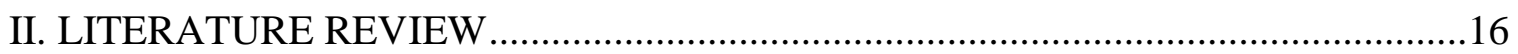

Basic Processes in Reading.............................................................................16

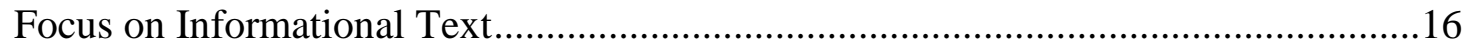

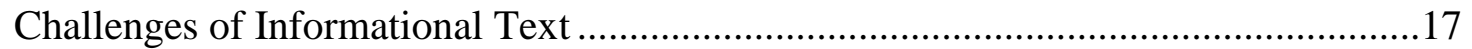

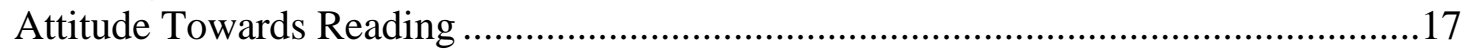

Effective Reading Comprehension Strategies ..........................................................19

Effective Reading Comprehension Strategies for Informational Text .......................21

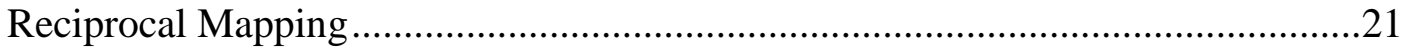

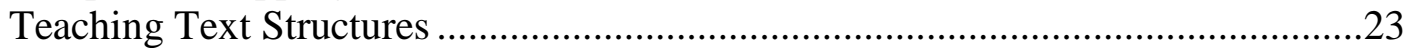

Matching Text Structures to Cognitive Structures...................................................29

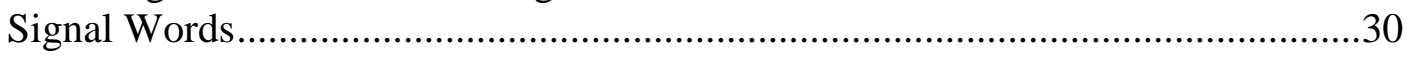

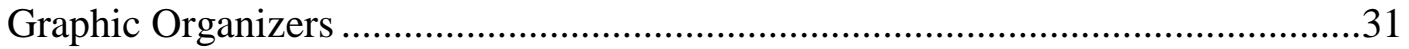

Characteristics of English Learners in Reading ...........................................................32

English for Speakers of Other Languages Functional Levels....................................32

World-Class Instructional Designs and Assessment Stages .......................................34

Instructional Support for English Learners.............................................................36

Adapting Reciprocal Mapping for English learners ...........................................37

Background Knowledge...............................................................................

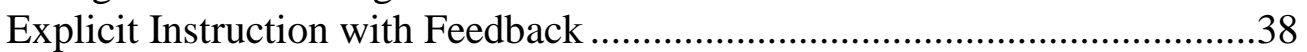

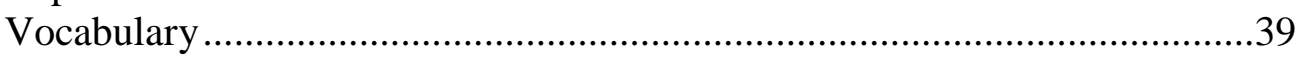

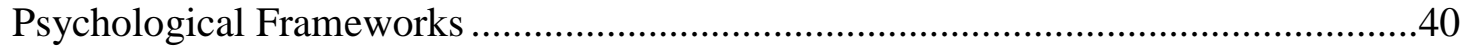

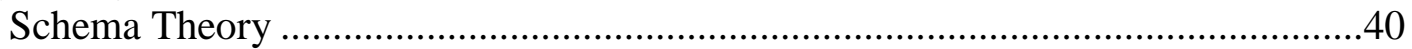

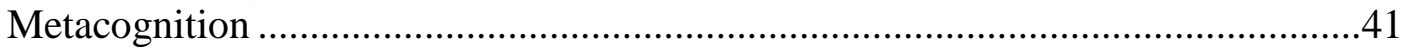

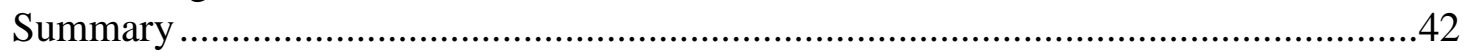

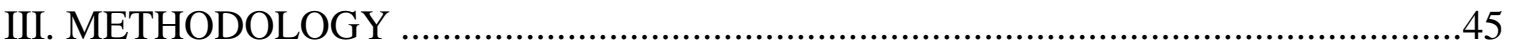

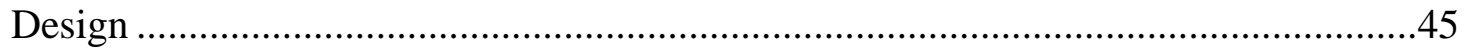

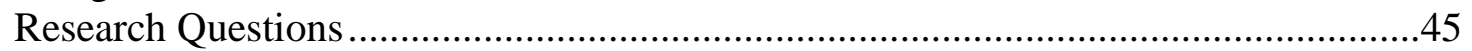

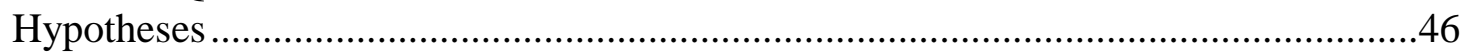

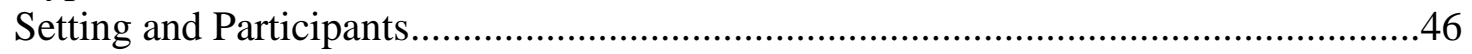

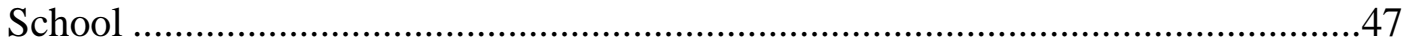

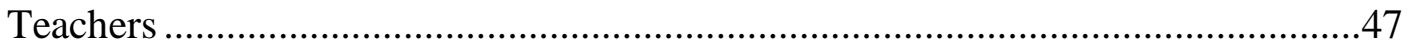




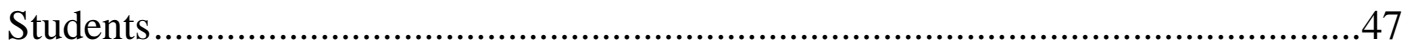

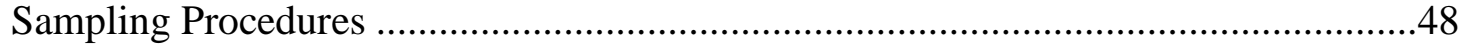

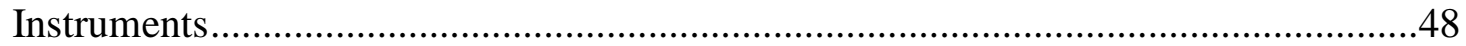

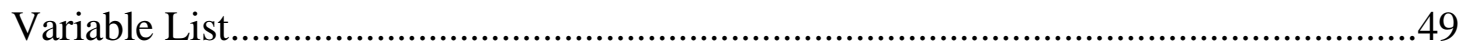

Treatment

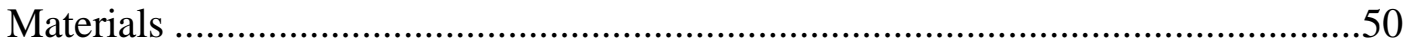

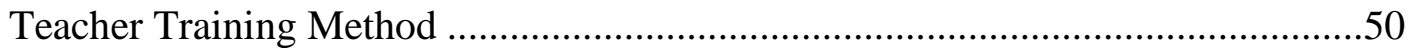

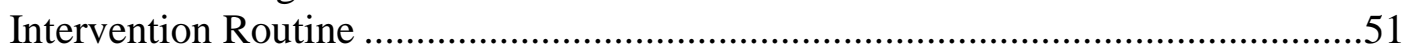

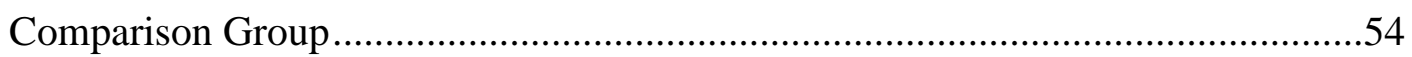

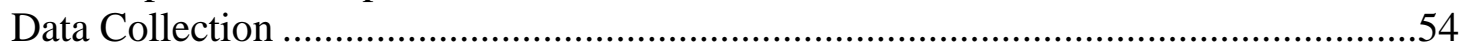

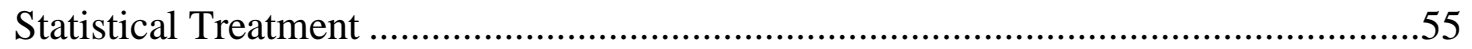

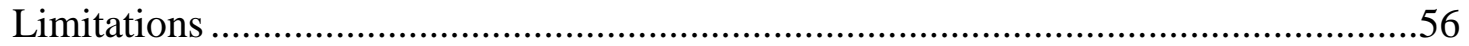

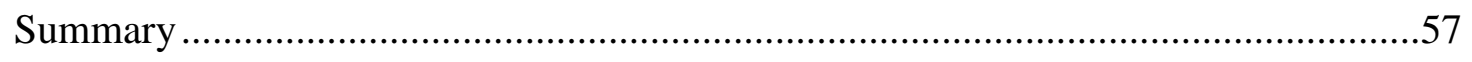

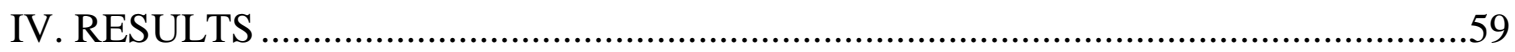

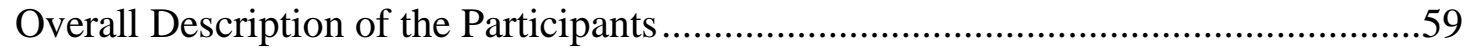

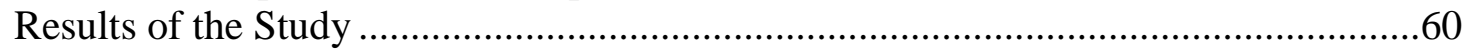

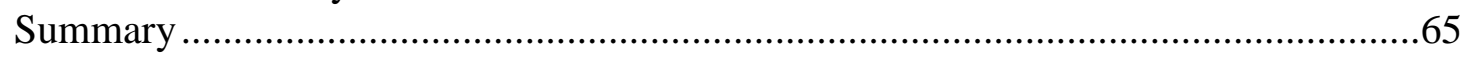

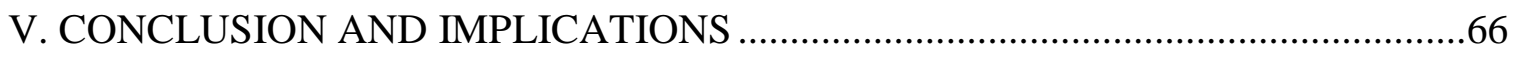

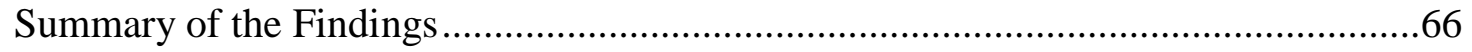

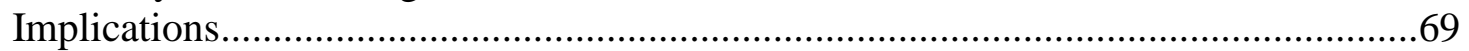

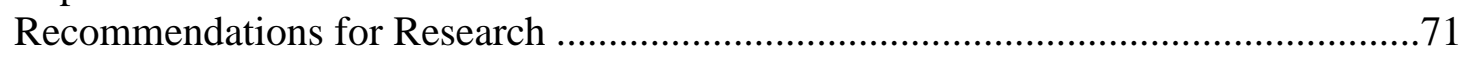

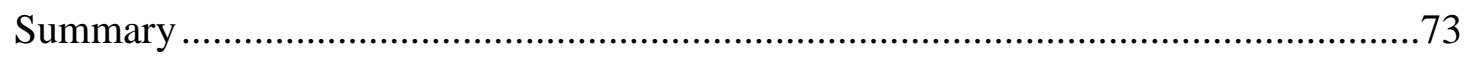

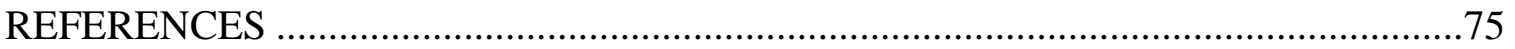

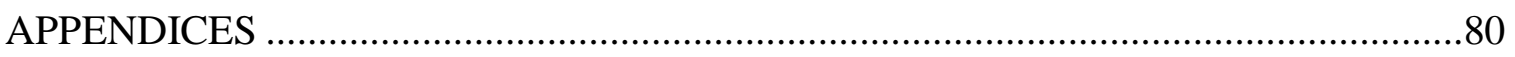

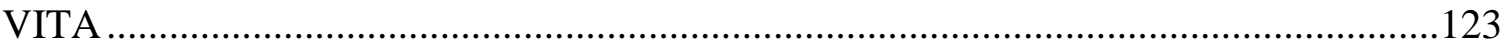




\section{LIST OF TABLES}

TABLE

PAGE

1. Fourth-Grade NAEP Reading Percentage of Proficiency by Student Groups.............2

2. Third-Fifth Grade FSA for ELA Percentage of Proficiency by Student Groups.........3

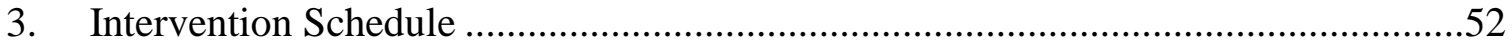

4. Intervention Routine for Treatment Group ....................................................53

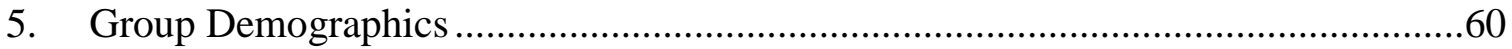

6. Group Differences of Post Reading Adjusted by Pre-test Score ............................62

7. Group Differences of Post Reading Adjusted by ESOL Membership ....................63 


\section{CHAPTER I}

\section{INTRODUCTION}

Reading comprehension is the process of simultaneously extracting and constructing meaning through interaction and involvement with written language (Snow, Science and Technology, and States, 2002). For many students, there is a decrease in reading achievement as early as fourth grade as a result of increased demands in complexity of intermediate text (Williams et al., 2005). Nationally, the National Assessment of Educational Progress (NAEP) states that only 37\% of fourth graders are proficient on the NAEP reading assessment (U.S. Department of Education, 2018). According to the 2017 NAEP Reading Framework, students achieving reading proficiency demonstrated competency over subject-matter knowledge, application of knowledge to real-world situations, and analytical skills. Nationally reading proficiency for student groups are described in Table 1 (U.S. Department of Education, 2018). 
Table 1

Fourth-grade NAEP Reading Percentage of Proficiency by Student Groups

\begin{tabular}{cc} 
Student Group & $\begin{array}{c}\text { Percentage at or Above } \\
\text { Proficiency }\end{array}$ \\
White & 47 \\
Black & 20 \\
Hispanic & 23 \\
Asian/Pacific Islander & 56 \\
Asian & 59 \\
Native Hawaiian / Other Pacific Islander & 27 \\
American Indian / Alaska Native & 20 \\
Two or More Races & 42 \\
Male & 34 \\
Female & 39 \\
(NSLP) & 22 \\
Eligible for National School Lunch Program & 52 \\
Not Eligible for NSLP & 12 \\
Students with Disabilities & 40 \\
Students without Disabilities & 9 \\
English language learners & 40 \\
Not English language learners & \\
\hline
\end{tabular}

Reading proficiency at the state level was reported by the Florida Department of Education (FLDOE). According to the FLDOE, 56\% of third, fourth, and fifth grade students in the state of Florida exhibited proficiency in reading by scoring a Level 3 or higher on the 2018 administration of the Florida Standard Assessments (FSA) for English Language Arts (ELA). Student performance on the FSA is categorized into five achievement levels, with Level 1 considered Inadequate; Level 2 Below Satisfactory; Level 3 Satisfactory; Level 4 Proficient; and Level 5 Mastery. State reading proficiency for student groups are described in Table 2 (FLDOE, 2018). 
Table 2

Third - Fifth Grade FSA for ELA Percentage of Proficiency by Student Groups

\begin{tabular}{ccc}
\hline Student Group & $\begin{array}{c}\text { State's Percentage at or } \\
\text { Above Proficiency }\end{array}$ & $\begin{array}{c}\text { Miami-Dade's } \\
\text { Percentage at or Above } \\
\text { Proficiency }\end{array}$ \\
\hline White & 67 & 78 \\
Hispanic & 53 & 63 \\
Black & 39 & 44 \\
Two or More Races & 61 & 73 \\
Asian & 80 & 81 \\
America Indian & 55 & 78 \\
Pacific Islander & 61 & 64 \\
English Language Learners & 23 & 28 \\
Non-English Language & 60 & 69 \\
Learners & & 29 \\
Students with Disability & 26 & 64 \\
Students without Disabilities & 61 & 55 \\
Economic Disadvantaged & 47 & 77 \\
Non-Economic Disadvantaged & 73 & \\
\hline
\end{tabular}

According to the FLDOE, students in Miami-Dade County Public Schools (MDCPS) exhibited similar reading proficiency levels on the state assessment. The FLDOE reported that $60 \%$ of third, fourth, and fifth grade students in MDCPS exhibited proficiency in reading by scoring a Level 3 or higher on the 2018 administration of the FSA. District reading proficiency for student groups in MDCPS are described in Table 2 (FLDOE, 2018).

According to the FLDOE, the Florida Standards Assessments measure students' achievement of Florida education standards. Florida has adopted a new set of English Language Arts standards known as the Language Arts Florida Standards (LAFS) that are derived from the Common Core State Standards (CCSS). The Florida Standards reflect the foundational expectations of what all students should know and be able to perform in kindergarten through $12^{\text {th }}$ grade. The Florida Standards promote the knowledge and 
skills needed to succeed in college, careers and life. These skills include critical thinking, problem solving and communication skills.

The LAFS requires a 50-50 balance between informational and literary reading in the elementary grades. Informational text is "text whose primary purpose is to convey information about the natural and social world" (Duke \& Bennett-Armistead, 2003, p. 17). Reading informational text contains high number of unfamiliar vocabulary and concepts, which can be challenging for some students to comprehend. For example, students who speak English as a second language possess a less extensive English vocabulary needed for comprehending informational texts (Ogle \& Correa-Kovtun, 2010).

Teachers have the critical task of supporting readers through their development of comprehending informational text, especially those readers still developing English. Students face stringent consequences when performing poorly on state assessments, such as retention or failing to graduate from high school. According to Weisberg (1990), recognizing text structure, constructing graphic organizers, and writing summaries are strategies that have helped students learn from informational text, especially when the students have limited prior knowledge on the topic.

The current study incorporated the Reciprocal Mapping (Fine, 2004) approach. The Reciprocal Mapping approach incorporates Weisberg's (1990) strategies of recognizing text structure, constructing graphic organizers, and writing summaries. Text structure refers to the organization of the text as a whole (Goldman \& Rakestraw, 2000). Meyer (1985) indicated the following structures of text: description, sequence, compare and contrast, cause and effect, and problem/solution. Reciprocal Mapping is an 
integrated reading/writing strategy, using visual representation to make concrete the process of examining the text structure of informational text. In using this strategy, students read text, identify the text structure, transfer information from the text to a graphic representation of the text structure, add any relevant background information and then write using the evidence from the text about the concepts being explained. An example of a Reciprocal Mapping (Fine, 2004) template used for studying the cause and effect text structure is shown in Figure 1. 


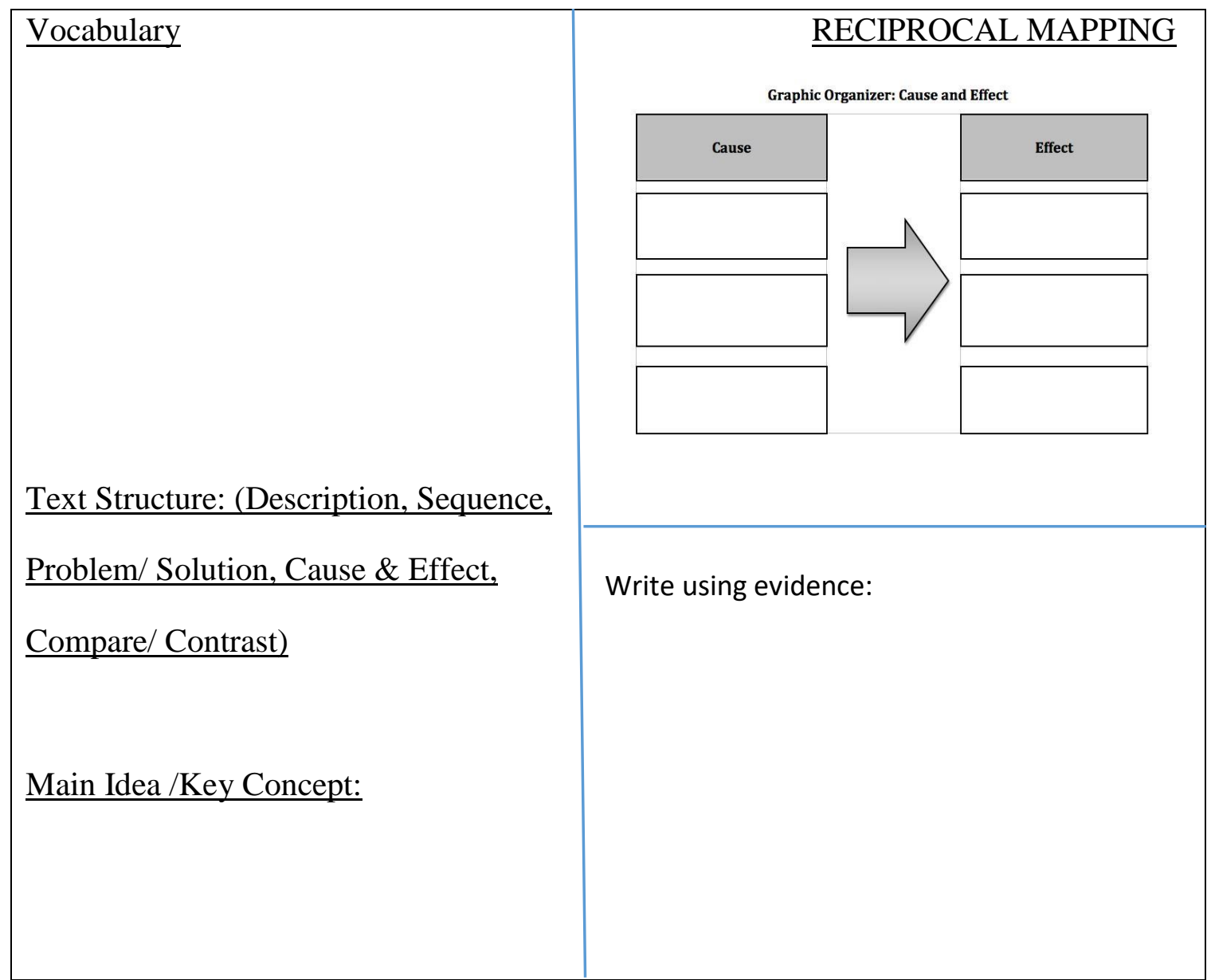

Figure 1. The Reciprocal Mapping template used for the cause and effect text structure.

The theoretical framework for the current study stems from a sociocultural perspective. "In a monocultural environment culture remains mostly invisible, and educators start paying attention to it only when two or more cultural patterns are empirically present in the same classroom at the same time" (Kozulin, 2003, p.15). Vygotsky's sociocultural perspective learning theory can be incorporated into these multicultural classrooms. "From the very first days of the child's development his activities acquire a meaning of their own in a system of social behavior and, being directed towards a definite purpose, are refracted through the prism of the child's environment” (Vygotsky, 1978, p.30). According to Goldenberg (2011), there is a significant research base on the impact of background knowledge in English learners' 
(ELs) reading comprehension. One suggestion on how to make lesson content more understandable to ELs is to use familiar content and linking new learning to the students' background and experience (Goldenberg, 2011). Many participants in the current study are ELs.

The key concept to the sociocultural perspective of learning is that of psychological tools (Kozulin, 2003). Psychological tools are a learner's artifacts, such as text and graphic organizers, that when internalized assist the learner in mastering psychological functions, such as perception and memory (Kozulin, 2003). The multicultural classroom incorporates cognitive education programs that assist in developing cognitive strategies and metacognitive skills for the attainment of higher-level cognitive functions specific to a curricular area (Kozulin, 2003). Metacognition emphasizes procedural knowledge, which includes the strategies needed to "become aware of, monitor, evaluate, and repair our comprehension” (Pearson, 2009, p. 15). According to Griffith and Ruan (2005), learners who employ metacognition are able to "monitor and regulate their learning processes to accomplish the learning goals they set" (p. 16). The current study used Reciprocal Mapping which incorporates students' backgrounds while developing their cognitive strategies and metacognitive skills for comprehending text. Figure 2 illustrates the theoretical framework of the Reciprocal Mapping (Fine, 2004) approach. 


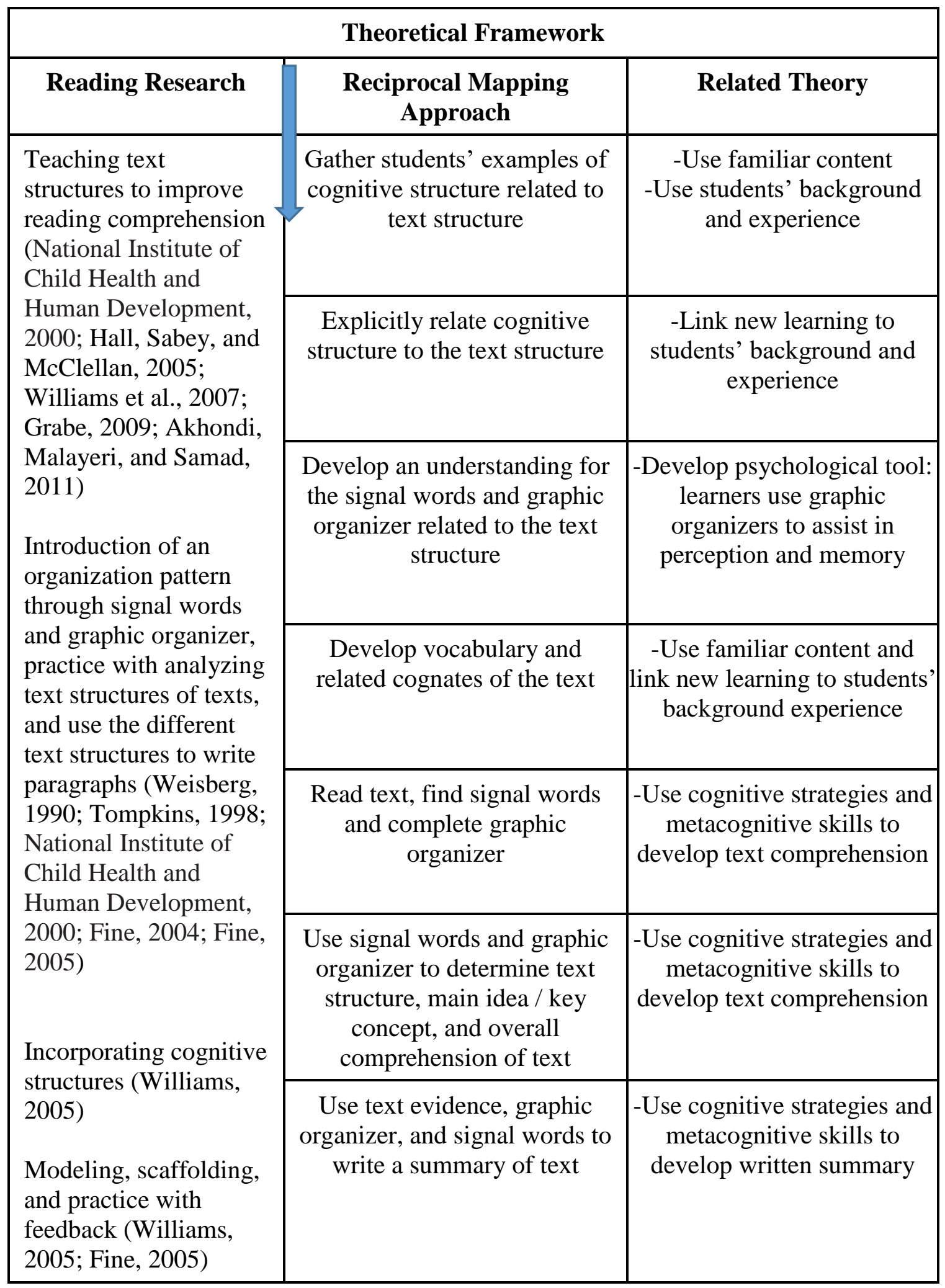

Figure 2. The components of the Reciprocal Mapping approach are correlated to its

theory. 
The current study was designed to investigate if developing third-grade students' knowledge of informational text structures, through a Reciprocal Mapping (Fine, 2004) approach, would impact their ability to comprehend informational text and impact their reading attitude. Chapter 1 includes the statement of the problem, purpose of the study, research questions and hypotheses, assumptions, delimitations, definitions and operational terms.

\section{Statement of the Problem}

According to the Common Core State Standards, "students must be immersed in information about the world around them if they are to develop the strong general knowledge and vocabulary they need to become successful readers and be prepared for college, career, and life" (National Governors Association Center for Best Practices, Council of Chief State School Officers, 2010, np). The Language Arts Florida Standards require comprehending informational texts, including history/social studies, science, and technical texts independently and proficiently.

As previously noted, comprehending informational text can be challenging for students. According to Hall, Sabey, and McClellan (2005), informational texts "contain more unfamiliar vocabulary and concepts, fewer ideas related to the here-and-now, and less information directly related to personal experience" (p. 212). National, state, and district reading proficiency levels indicate that there is a need to research instructional methods that might increase reading achievement. According to Goldenberg (2011), in the area of reading comprehension, there is a lack of "robust evidence base about the impact of strategy instruction on ELs' comprehension” (p. 697). 
Petscher (2010) indicates a moderate relationship between reading attitude and achievement and expresses the importance of further research on understanding how reading attitude may interact with other psychosocial constructs, and how reading attitude may be strengthened. Reading attitude is "a system of feelings related to reading which causes the learner to approach or avoid a reading situation" (Fishbein \& Ajzen, 1975, p. 1). McKenna, Kear, and Ellsworth (1995) subcategorize reading attitude into the student's reading attitude for recreation (personal use) and reading attitude for academic (school-related use). McKenna et al. found that attitude towards reading both for recreational and academic grew increasingly negative as students moved from first to sixth grade, with larger declines in academic reading attitude. When analyzing for reading attitude and ability, the authors indicate significant main effects of a reader's history of success or frustration and its role in shaping reading attitude. Recreation reading attitude grows increasingly negative for least able readers. However, in academic reading attitude the negative trend is similar with all types of reading abilities; meaning, a decrease in academic reading attitude was not related to reading ability. The need to conduct the current study was driven by the current reading proficiency levels, an overall decline in reading attitude from Grade 1 to Grade 6, and the high demands of comprehending informational text.

\section{Purpose of the Study}

The purpose of the study was to examine the effect of a comprehensive reading strategy approach, Reciprocal Mapping (Fine, 2004), on reading achievement and reading attitude of a sample of third grade students. In using the strategy, students read text, identify the text structure, transfer information from the text to a graphic representation of 
the text structure, add any relevant background information and vocabulary, and then write using the evidence from the text about the concepts being explained. Specifically, the study examined:

1. The effects of the Reciprocal Mapping (Fine, 2004) approach on third-grade students' ability to comprehend informational text.

2. The effects of the Reciprocal Mapping (Fine, 2004) approach on third-grade students' reading attitude.

\section{Research Questions}

The following research questions were addressed in this study.

Question 1: Is there a difference in reading comprehension levels of third-grade students taught with standards-based instruction on science informational text with the Reciprocal Mapping (Fine, 2004) approach than third-grade students taught with standards-based instruction without the Reciprocal Mapping approach?

Question 2: Is there a difference in reading attitude of third-grade students taught with standards-based instruction with the Reciprocal Mapping (Fine, 2004) approach than third-grade students taught with standards-based instruction without the Reciprocal Mapping approach?

\section{Assumptions}

1. The participants are a representative sample of third-graders and third-grade English learners from a large urban area.

2. The participants have had limited exposure to informational text structure instruction in their previous grades. 
3. The participants were not provided instruction in informational text structures outside of class during the time of the study.

\section{Delimitations}

This study was delimited to third-grade students, which include English learners, who live in a large urban school district in Florida. The students' families are representative of Spanish-speaking countries from mostly Central-America and the Caribbean. The study was delimited to English learners who are at least at an English for Speakers of Other Languages (ESOL) functional level III. English learners who are an ESOL functional Level I or II may not have acquired basic English vocabulary to accurately exhibit reading comprehension levels. According to Miami Dade County Public Schools (n.d.), students with an ESOL functional level III and IV read with understanding of longer selections appropriate to grade level. The study was delimited to measure the students' comprehension of informational text by the students' test score on a school district's computerized reading assessment. The researcher is bilingual and a general education, classroom teacher with a Master of Science in Reading and Special Education degree.

\section{Definitions and Operational Terms}

\section{Cognates}

"Cognates are those words in Spanish and English that share the same etymology, have identical or nearly identical spelling, and have the same or similar meanings, depending on the context of their use" (Hernandez, Montelongo, \& Herter, 2016, p. 34). Solid and sólido, liquid and líquido, and gas and gas are examples of science cognates. 


\section{English Learners}

According to the National Council of Teachers of English (2008), an English language learner is "an active learner of the English language who may benefit from various types of language support programs" (p. 2).

\section{English for Speakers of Other Languages (ESOL) Functional Levels}

Miami Dade County Public Schools (n.d.) describes the characteristics of the five functional levels of an English learners' understanding of spoken language, use of grammatical structure, pronunciation, vocabulary, and reading comprehension. The five functional levels are described as Level I, Novice; Level II, Low Intermediate; Level III, High Intermediate; Level IV, Advanced; and Level V, Independent.

\section{Florida Standards}

According to Florida Students Achieve (n.d.), the Florida Standards reflect the foundational expectations of what all students should know and be able to do in each grade level. The Florida Standards promote the knowledge and skills needed to succeed in college, careers and life. These skills include stronger critical thinking, problem solving and communication skills.

\section{Graphic Organizers}

According to Darch and Eaves (1986), graphic organizers "attempt to facilitate the initial teaching and the study of textual material by using lines, arrows, and spatial arrangements that describe text content, structure, and key conceptual relationships" (pp. 309-310). 


\section{Informational Text}

Informational text is "text whose primary purpose is to convey information about the natural and social world" (Duke \& Bennett-Armistead, 2003, p. 17).

\section{Reading Attitude}

Reading attitude is "a system of feelings related to reading which causes the learner to approach or avoid a reading situation" (Fishbein \& Ajzen, 1975, p. 1). McKenna and Kear (1990) subcategorize reading attitude into the student's reading attitude for recreation (personal use) and reading attitude for academic (school-related use). In the current study, reading attitude is measured through the Elementary Reading Attitude Survey (McKenna \& Kear, 1990).

\section{Reading Comprehension}

According to Snow et al. (2002), reading comprehension is the process of simultaneously extracting and constructing meaning through interaction and involvement with written language. In the current study, reading comprehension was measured by the students' reading performance on the first and second administration of the district provided computerized i-Ready Diagnostic.

\section{Reading Strategies}

Afflerbach, Pearson, and Paris (2008) state that "Reading strategies are deliberate, goal-directed attempts to control and modify the reader's efforts to decode text, understand words, and construct meanings of text" (p. 368).

\section{Reciprocal Mapping}

Reciprocal Mapping is an integrated reading/writing strategy, using visual representation to make concrete the process of examining author's craft. Students 
read text, under the direct and explicit instruction of the teacher, as they create graphic organizers depicting the targeted text structure. Students come to appreciate the authentic ways authors write; by appreciating and paralleling the techniques authors use, students indirectly experience an author's apprenticeship. (Fine, 2004, p.89)

\section{Signal Words}

According to Crosson, Lesaux, and Martiniello (2008), connectives (also referred to as connectors and signals) “act as guiding cues that can assist readers' understanding of how ideas in one clause relate to those in adjacent clauses" and "are difficult to infer from context" (pp. 603-604).

\section{Text Structure}

The structure aspects of text refer to the organization of the text as a whole (Goldman \& Rakestraw, 2000). Meyer (1985) indicated the following text structures: description, sequence, compare and contrast, cause and effect, and problem/solution. Anderson and Armbruster (1984) include explanations of concepts and definition and example as text structures.

\section{Summary}

Chapter 1 discussed how the new Language Arts standards are requiring the incorporation of informational text into the elementary classrooms. The challenges of comprehending informational text were described, including how they relate to English learners. The possible relationship between reading attitude and reading achievement was discussed. The study's sociocultural perspective was described. The delimitations and definitions of key terms of the study were explained. 


\section{CHAPTER II}

\section{LITERATURE REVIEW}

\section{Basic Processes in Reading}

In the decade of the 1970s, psychologists studied the basic processes in reading, with one group focusing on characteristics of the text and the second group on the knowledge students bought to the reading task (Pearson, 2009). The group who studied the text contributed to the knowledge of how readers use the structure of text to enhance comprehension. According to Snow, Science and Technology, and States (2002), reading comprehension is the process of simultaneously extracting and constructing meaning through interaction and involvement with written language. Some researchers studied the text structure of narratives otherwise known as story grammar (Rumelhart, 1977); while others studied the text structure of expository texts (Meyer, 1975).

\section{Focus on Informational Text}

According to Duke and Bennett-Armistead (2003), informational text is "text whose primary purpose is to convey information about the natural and social world" (p. 17). As noted earlier, the Common Core State Standards (CCSS) and Language Arts Florida Standards (LAFS) require a 50-50 balance between informational and literary reading in the elementary grades. The CCSS aim for students to have extensive opportunities to build knowledge through texts to build successful readers and independent learners who are prepared for college, career, and life. The LAFS require the students to think strategically and perform complex reasoning in order "describe the relationship between a series of historical events, scientific ideas or concepts, or steps in 
technical procedures in a text, using language that pertains to time, sequence, and cause/effect" (np).

\section{Challenges of Informational Text}

According to Hall, Sabey, and McClellan (2005), informational texts "contain more unfamiliar vocabulary and concepts, fewer ideas related to the here-and-now, and less information directly related to personal experience" (p. 212). The primary curriculum has traditionally emphasized narrative text, while neglecting expository text (Duke, 2000). Snow, Burns, \& Griffin (1998) advocate incorporating expository text into the primary curriculum to better prepare the students for the challenges of the intermediate grades. Decrease in reading achievement is evident as early as fourth grade due to demands of reading intermediate text (Williams et al., 2005). The National Assessment of Educational Progress (NAEP) states that only 37\% of fourth graders are at or above proficient on the reading assessment (U.S. Department of Education, 2018).

\section{Attitude Towards Reading}

The following three concepts help us understand attitude: "the beliefs an individual harbor in relation to the object, the behavioral intentions that concern the object, and the feelings the individual experiences because of the object" (McKenna et al., p. 937, 1995). Attitude as it relates to reading is "a system of feelings related to reading which causes the learner to approach or avoid a reading situation" (Fishbein \& Ajzen, 1975, p. 1)

McKenna, Kear, and Ellsworth (1995) relate attitude towards reading by providing several influential factors with instructional approaches producing more

successful experiences as one of them. These instructional approaches that lead to 
successful experiences can contribute directly and cumulatively to attitude, which can influence to more positive beliefs about the outcomes of reading (McKenna et al., 1995).

McKenna et al. (1995) investigated reading attitude throughout the United States through the Elementary Reading Attitude Survey (McKenna \& Kear, 1990). This survey subcategorizes reading attitude into the student's reading attitude for recreation (personal use) and reading attitude for academic (school-related use). The authors found that attitude towards reading for both recreational and academic purposes grew increasingly negative as students moved from first to sixth grade, with larger declines in academic reading attitude. Reading attitude in Grade 1 begin relatively positive and end in relative indifference by Grade 6. When analyzing for reading attitude and ability, the authors indicate significant main effects of a reader's history of success or frustration and its role in shaping reading attitude. This trend is most rapid for least able readers. However, in academic reading attitude the negative trend is similar with all types of reading abilities. Meaning, a decrease in academic reading attitude was not related to reading ability. Lastly, the authors did not find ethnicity to influence the negative trend in recreational or academic reading attitude.

Petscher (2010) conducted a meta-analysis of the relationship between attitude in reading and achievement in reading to investigate the magnitude and overall importance of this relationship. The author indicates that the mean strength of the relationship between reading attitude and achievement is moderate $\left(Z_{r}=.32\right)$, while stronger for students in elementary school $\left(Z_{r}=.44\right)$ when compared with middle school students $\left(Z_{r}\right.$ $=.24$ ). In other words, elementary students' reading achievement was found to be 
correlated to their reading attitude. The author expresses the importance of further research on what interventions help sustain positive reading attitude into middle schools.

\section{Effective Reading Comprehension Strategies}

According to Afflerbach, Pearson, and Paris (2008), "Reading strategies are deliberate, goal-directed attempts to control and modify the reader's efforts to decode text, understand words, and construct meanings of text" (p. 368). According to Snow et al. (2002), reading comprehension is the process of simultaneously extracting and constructing meaning through interaction and involvement with written language. According to Duke and Carlisle (2011), reading comprehension occurs when the reader creates a mental representation of the meaning of text, through the use of the following interacting factors: the text (its language, content, structure, purpose, and features), the reader (existing knowledge base, views, purposes, processes, strategies, and skills), and the context where the communication is occurring.

Reading strategies are found in many core reading programs, intervention programs, and instructional approaches. The following question remains: What is an effective approach to develop students' reading strategies? The National Reading Panel (NRP) report (National Institute of Child Health and Human Development [NICHD], 2000) notes seven instructional strategies that have solid scientific foundation and are closely related to reading strategies and metacognition: comprehension monitoring, cooperative learning, use of graphic and semantic organizers, question answering, question generation, use of story structure, and summarization. These recommendations were not based on research with ELs. 
According to Marcell, DeCleene, and Juettner (2010), in spite of systematic and explicit reading strategy instruction, daily think-alouds, and the gradual release of responsibility of the teacher to student, students can 'talk the strategy talk but don't walk the application walk" (p. 687). In other words, the students can vocalize the strategies but do not independently use the strategies. The goal of strategy instruction is for the reader to use a suitable strategy, as needed, depending on the reading purpose and text structure and difficulty. Marcell, et al. (2010), brainstormed reasons independent reading strategies are not implemented and describe instructional practice to assist with independent application. For instance, the authors suggest reading instruction is too guided and the strategies are taught in isolation instead of using an integrated approach. Reading strategies instruction alone is necessary for reading comprehension development, but may be insufficient, perhaps meaning there is a need for developing students' metacognition as to when to apply which strategy.

Dewitz, Jones, and Leahy (2009) have analyzed the current core reading programs' strategy instruction. Most of the programs studied lacked practice of the skills and strategies throughout the entire program. The authors also found that the programs seldom asked students to model the skills and strategies being taught. Dewitz et al., (2009) note the deficiencies of these core reading programs, as it relates to reading strategies, as (1) skills and strategies are wide but not deep, (2) structures of skills are not interconnected, (3) skills are not scaffolded, and (4) guided practice of skills is lacking, which highly impacts the weakest readers.

An issue with reading strategy instruction is how to develop the students' ownership of the strategy. According to Keene (2011), students are more likely to 
remember and reuse what they have read and/or learned about when they understand more deeply. Through her research, the author has found certain indicators or markers of deeper understanding. Two of these indicators or markers of deeper understanding are (1) recognizing patterns and themes of the text and (2) developing original ideas inspired by the text. These original ideas can be produced through written, artistic, or dramatic artifacts.

\section{Effective Reading Comprehension Strategies for Informational Text}

\section{Reciprocal Mapping}

The current study investigates the effectiveness of using the Reciprocal Mapping approach on third-grader students that include English learners. According to Fine (2004),

Reciprocal Mapping is an integrated reading/writing strategy, using visual representation to make concrete the process of examining author's craft. Students read text, under the direct and explicit instruction of the teacher, as they create graphic organizers depicting the targeted text structure. Students come to appreciate the authentic ways author write; by appreciating and paralleling the techniques authors use, students indirectly experience an author's apprenticeship. Reciprocal Mapping is designed to be a leading activity, one that takes students to a higher level of cognition. (p.89)

An example of a Reciprocal Mapping template used in the current study is found in Figure 1, page 6. Reciprocal Mapping is a comprehension strategy which combines several evidenced-based strategies to identify text structure and use graphic organizers to be able to write about a topic. Students identify and include evidence from text, add prior 
related knowledge and key vocabulary, and then write original summaries of the information. Combining evidence-based strategies is part of an instructional wave to integrate strategies to benefit students' metacognitive thinking. Figure 2, found in page 8 , illustrates how the components of Reciprocal Mapping is based on theoretical knowledge.

According to Fine (2005), Reciprocal Mapping assists with the development of metacognition when the reader understands how to select the most important information for retention. In addition, this strategy incorporates some of the following National Reading Panel's reading strategies (National Institute of Child Health and Human Development [NICHD], 2000): use of graphic and semantic organizers and story structure. Furthermore, Reciprocal Mapping provides scaffolding, guided practice, and application, which according to Dewitz et al. (2009) are deficiencies of core reading programs. According to Fine (2005), the graphic organizer provides scaffold and guided practice, which will aid the students in transferring their understanding to other texts; as they become more familiar with text structures and patterns, their comfort, motivation, and reading comprehension level is affected. In addition, Reciprocal Mapping aims to develop the students' ownership of the strategy by having them write a piece of writing based on the text structure studied. Recognizing patterns of the text and producing written artifacts inspired by text is one method of developing deeper understanding and ownership of the strategy (Keene, 2011). Incorporating writing instruction with text structures instruction improves the quality of the students' writing (Graham, McKeown, Kiuhara, \& Harris, 2012). 
According to Cash (2013), there was a significant difference between the treatment and control group's posttest scores of social studies content knowledge. The Reciprocal Mapping treatment group received instruction on text structure and the structure's related signal words and graphic organizers during the social studies class. A variety of texts, such as textbook, passages, and trade books were used for the Reciprocal Mapping treatment. The control group received traditional instruction found in typical classrooms. The treatment took place during a five-week period. The study used a pretest/posttest control group experimental design. The pretest and posttest consisted of the textbook's chapter tests that measured social studies content. The sixth-grade students were considered struggling readers due to their poor performance on the state reading assessment. The results indicated a statistically significant difference in the posttest scores which measured gain in social studies content knowledge.

According to Weisberg (1990), recognizing text structure, constructing graphic organizers, and writing summaries are strategies that have helped students learn from informational text, especially when the students have limited prior knowledge on the topic. The students' comprehension increased when using these strategies because they were actively engaged in learning and monitoring their understanding. Weisberg (1990) explained that these strategies increase the students' cognitive awareness of what affects comprehension, while using a problem-solving approach to learning.

\section{Teaching Text Structures}

According to Akhondi, Malayeri, and Samad (2011), teaching text structures of expository texts may be an effective technique to improve reading comprehension and retention. The structure aspects of text refer to the organization of the text as a whole 
(Goldman \& Rakestraw, 2000). Meyer (1985) indicated the following text structures: description, sequence, compare and contrast, cause and effect, and problem/solution. Anderson and Armbruster (1984) include explanations of concepts, definitions, and examples as text structures. Meyer, Wijekumar, and Lin (2011) developed a structure strategy that enables students to use text structures to increase comprehension. According to the authors, the structure strategy seeks coherence among text ideas. When identifying text structures as a strategy, a reader understands that texts are structured in a predictable way and the reader "can construct an integrated representation of a text by following the hierarchical organization of the text and the relative importance of its conceptual content" (Meyer et al., 2011, p. 141). Understanding text structure "may provide readers with valuable information about how to approach the text and assist them in identifying important information to remember from the text" (Hebert, Bohaty, Nelson, \& Brown, 2016, p. 621).

Weisberg (1990) described the following steps in teaching expository text structure: (1) explain why recognition of text structure improves comprehension, (2) explain what the term means (i.e., compare \& contrast), (3) teach the signal words that reflect the text structure, (4) teach questioning while reading (what is the topic, what do I know about the topic, and how does the topic relate to the text structure), (5) mark signal words, (6) construct a graphic organizer, and (7) write summaries from the graphic organizer. Tompkins (1998) suggested the following three steps in teaching text structure: introduction of an organization pattern through signal words and graphic organizer, practice with analyzing text structures of texts, and use of the different text structures to write paragraphs. Williams (2005) elaborates on the instructional design 
and includes introducing content in small increments, modeling, scaffolding, and practice with feedback. Reciprocal Mapping incorporates Tompkins' (1998) and Williams' (2005) instructional designs.

The following are studies that investigated the effectiveness of implementing text structure instruction for improving reading comprehension. Williams et al. (2007) studied the outcomes of implementing an explicit and structured instructional model that emphasized the cause and effect text structure in social studies texts to improve comprehension. This instruction model explained, modeled, guided and provided independent practice of cause and effect text structures. The lessons incorporated clue words, generic cause and effect questions, graphic organizers, well-structured paragraphs, and informational trade books related to social studies content being studied. In addition, key vocabulary words that were content specific were taught. The participants of the study included fifteen classroom teachers from three Title I elementary schools with similar demographics (76\% Hispanic, 22\% African American, 0.5\% European American, and $1 \%$ Asian or other). About $5 \%$ of the students were enrolled in special education services. The classrooms were randomly assigned to one of three conditions: text structure program, comparison content-only program, or no instruction control. The comparison content-only program used the same materials as the text structure program but did not focus on the cause and effect aspect of the program. Each condition contained five second grade teachers and 243 students. The authors selected 12 students from each class for statistical analysis $(N=60)$. The authors used a pretest-posttest design. The pretest involved the Word identification and Passage Comprehension subtests of the Wood-cock Reading Mastery Test-Revised (WRMT-R) and three strategy and two 
outcome measures. These strategy measures asked the students to locate clue words, cause and effect clauses, and recall cause and effect questions. The outcome measures assessed the students' knowledge of vocabulary concepts and their ability to provide cause and effect statements based on comprehension questions. The posttest involved a different form of the WRMT-R and an extensive array of strategy and outcomes measures. These strategy measures asked the students to locate clue words, underline clauses, complete a graphic organizer for a cause and effect paragraph, and recalling cause and effect questions. The outcome measures included content and comprehension measures. Williams et al. (2007) described their results as the text structure group scoring higher than the other groups on the effect questions but not on the cause questions. The overall effect of treatment on the students' ability to answer questions related to the structure of the text indicates instruction in text structure impacts the students' ability to understand clauses in the text suggesting that teaching text structure is worthy of future study.

Hall et al. (2005) investigated the effectiveness of teaching expository text structures during guided reading to second grade students. There were 72 second grade students in six classrooms. However, the final analysis only included five classrooms due to fidelity of the treatment. The students were part of one elementary school located in the western part of the United States. The school was designated as a Title I school with $46 \%$ of the population receiving free or reduced lunch. The school's population ethnicity consisted of approximately $87 \%$ of Caucasian, $11 \%$ Hispanic, $1 \%$ Pacific Islander, and 1\% Asian/Other. In addition, approximately $12 \%$ of the school's population qualifies to receive support for their limited English proficiency. 
In the Hall et al. (2005) study, each classroom was randomly assigned one of three groups: Text Structure, Content, and No Instruction. All of the groups read material related to animal classification. The Text Structure group $(N=31)$ received instruction on text structure awareness. The Content group $(N=17)$ received instruction on background knowledge and vocabulary. The No Instruction $(N=24)$ group received their regular instruction. The Text Structure program involved introducing the content of the book, major vocabulary, and clue words, having the students read the text aloud, and discussing the text for comprehension through the completion of a graphic organizer and written summary. The Content program introduced the text in the same manner as the Text Structure program except it did not include a discussion on clue words or examination of comparisons. After the text was read in the same manner as the Text Structure program, the text was discussed by reviewing the target vocabulary words and major concepts. Then, the students organized the information of the text through a graphic organizer that highlights the main topics and subtopics instead of comparison. Lastly, the students completed a summary of the text. The No Instruction group was not observed; however, during the teacher debriefing meetings, the teachers described the content and strategies they focused on during guided reading.

Hall et al. (2005) used a pre / post multi-group comparison design. The preassessment consisted of the Word Knowledge and Comprehension subtests of the GatesMacGinitie Reading Test and an assessment written to assess the particular aspects of the instructional program being implemented in the study (summary of compare/contrast text, clue words, matrix, and vocabulary). The post-assessment involved the same measures as the pre-assessment except for the Gates-MacGinitie Reading Test. There 
was no overall effect of treatment on the students' ability to summarize a

compare/contrast paragraph about content unrelated to the instructional program or define key vocabulary words related to animal classification. However, there was an overall effect of treatment on the students' ability to summarize a compare/contrast paragraph about content related to the instructional program, but not seen during instruction. In addition, there was an overall effect of treatment on the students' ability to summarize a compare/contract paragraph seen during the instructional program. The students in the treatment group scored significantly higher on their ability to recall a list of clue words, organize information from the text through the use of a graphic organizer, use clue words in their summaries, and exhibit a conceptual understanding of compare and contrast. Overall, there was no significant difference between the Content group and the No Instruction group in all of the different measures. The overall effect of treatment on the students' ability to summarize a compare/contrast paragraph not seen during instruction indicates instruction in text structure transfers to other novel text suggesting that teaching text structure is worthy of future study.

A systemic descriptive historical review was conducted on the methodological trends of expository text instruction efficacy research (Bohaty, Hebert, Nelson, \& Brown, 2015). This historical review found that the majority of the studies reviewed did not report demographic information. For example, only $18 \%$ of the studies included information on the participants' ethnicity and 3\% of their student status (i.e., English learner). This review found that only $18 \%$ of the studies reviewed taught all five text structures in their study. The authors believe that text structure instruction should be comprehensive and include all five text structures (Bohaty et al., 2015). 
A recent meta-analysis was conducted to determine the effectiveness of text structure instruction across a range of participants and contexts (Hebert et al., 2016). The studies included in the meta-analysis were studies that taught at least one text structure, were experimental, quasi-experimental, or counterbalanced in design, with participants in Grades 1 through 12, with an expository reading comprehension outcome measure, or norm-referenced measure of reading comprehension. The effect sizes were based on expository reading comprehension outcome variables and norm-referenced reading comprehension outcomes. This meta-analysis indicates that text structure instruction improves expository reading comprehension $(E S=0.57)$, including for students with or at-risk for disabilities. In addition, the inclusion of more text structures and writing in the study were significant predictors of the effectiveness of the intervention.

Teaching text structures of informational text through the Reciprocal Mapping (Fine, 2004) approach was the essence of the current study. The current study included the development of all five informational text structures and a writing component, as recommended by the literature review.

\section{Matching Text Structures to Cognitive Structures}

Williams (2005) adds that these specific structures found in text are not limited to text; "they are rhetorical structures that reflect universal cognitive processes" (p. 7). These universal cognitive processes are reflective in the thinking of children such as comparing objects and situations or determine casual links in events. According to Williams (2005), the goal of teaching text structure is to assist the students in recognizing and matching these text structures to cognitive structures in order to understand and produce text and spoken discourse. In addition, the goal involves being able to simplify 
or reorganize poorly organized text or text that contains complex structures in order to facilitate comprehension of written discourse.

\section{Signal Words}

According to Crosson, Lesaux, and Martiniello (2008), connectives (also referred to as connectors and signals) "act as guiding cues that can assist readers' understanding of how ideas in one clause relate to those in adjacent clauses" and "are difficult to infer from context" (pp. 603-604). According to the authors, a poor understanding of connectives may contribute to reading comprehension difficulties. Specifically, the authors studied the influence of specific oral language competencies on language minority students' understanding of connectives. The language minority students selected for the study were 90 fourth graders of Spanish-speaking backgrounds receiving bilingual literacy instruction in a large, urban school district in the southwestern United States. The students were enrolled in three different schools and all were from low socioeconomic status backgrounds. The following measures were administered: Peabody Picture Vocabulary Test for vocabulary knowledge, Woodcock Language Proficiency Battery for word reading accuracy, Test of Oral Word Reading Efficiency for word reading fluency, WLPB-R listening comprehension subtest for listening comprehension, and Text Cohesion Task (TCT) for measuring use of connectives. The authors found a moderate and significant correlation between all three languages and reading variables with TCT scores. The authors investigated which oral language and word reading skills contributed to the understanding of connectives through hierarchical regression analyses. The model predicts that students with low vocabulary knowledge and listening comprehension skills tend to have a poorer grasp of connectives. 
The assessments in the Crosson et al. (2008) study were not conducted in the students' home language, therefore, the findings may not exhibit the students' overall reading skills in their home language. Positive effects of teaching text structure with signal words were found with mostly monolingual students in the fourth grade in the Meyer, Wijekumar, and Lei's (2018) study. According to Meyer et al., the text structure intervention was effective in assisting students in generating better comparative signal words as compared to the control group. The explicit teaching of signal words within the Reciprocal Mapping strategy was incorporated in the current study.

\section{Graphic Organizers}

As noted earlier, The NRP report (National Institute of Child Health and Human Development [NICHD], 2000) notes seven instructional strategies that have solid scientific foundation and are closely related to reading strategies and metacognition, of which the use of graphic and semantic organizers and summarization is included. According to Griffin, Malone, Kameenui (1995), the graphic organizer, referred as a structured overview, was developed as an attempt to translate Ausubel's (1968) cognitive theory of meaningful reception learning into practice. This theory argued that an individual's existing knowledge or cognitive structure influences the acquisition of new knowledge in a content area. Ausubel (1968) argued that strengthening these cognitive structures assist learning and retention. According to Darch and Eaves (1986), graphic organizers "attempt to facilitate the initial teaching and the study of textual material by using lines, arrows, and spatial arrangements that describe text content, structure, and key conceptual relationships" (pp. 309-310). Weisberg (1990) added that when students are able to visualize these relationships, they are better able to remember important ideas. 
According to Pang (2013), visual tools, such as graphic organizers and homemade picture books, can assist English learners with reading comprehension. The author recommends that students relate to the text by composing a book themselves about the topic or events in the text. The students share their experiences as it relates to the text in order to improve oral language, discourse skills, and overall reading comprehension. Pang's (2013) recommendation of having the students use graphic organizers and share their experiences as it relates to the text was incorporated in the current study.

\section{Characteristics of English Learners in Reading}

According to the National Council of Teachers of English (NCTE), an English Language Learner is "an active learner of the English language who may benefit from various types of language support programs". According to the National Center for Education Statistics (NCES), in the 2012-2013 school year, 9.2\% of the student population were participating in programs for English learners.

\section{English for Speakers of Other Languages Functional Levels}

Miami Dade County Public Schools (n.d.) identify five major stages of English language development and provide characteristics of the English for Speakers of Other languages (ESOL) functional levels. The functional levels are labeled Level 1 (Novice), Level 2 (Low Intermediate), Level 3 (High Intermediate), Level 4 (Advanced), and Level 5 (Independent). The characteristics of these functional levels relate to areas of understanding spoken language, using grammatical language, pronunciation, vocabulary, and reading. The characteristics developed by MDCPS (n.d.) are described as follows:

In understanding spoken language, the Novice (Level 1) English learner constantly tries to resort to his or her home language with very little understanding of 
spoken English. The Low Intermediate (Level 2) English learner demonstrates limited understanding and most always carefully chooses words in familiar classroom situations. The High Intermediate (Level 3) English learner often chooses words carefully within familiar contexts. The Advanced (Level 4) English learner demonstrates extensive understanding and only occasionally restates ideas to clarify concepts, while the Independent (Level 5) English learner is comparable to a native speaker with occasionally needing clarification.

In using grammatical structure, the Novice (Level 1) English learner's verbal expression is limited and grammatically incorrect and cannot communicate meaning orally or written. The Low Intermediate (Level 2) English learner's expression of concepts taught are incomplete or incorrect with errors in common grammatical structures. The High Intermediate (Level 3) English learner's expression of ideas contain many significant grammatical errors. The Advanced (Level 4) English learner's expression can be understood even with an occasional significant grammatical error, while the Independent (Level 5) English learner makes few grammatical errors and can rephrase errors to increase the listener's understanding.

In vocabulary, the Novice (Level 1) English learner uses extremely limited vocabulary and is unable to participate in class discussion. The Low Intermediate (Level 2) English learner always fumbles for high frequency words and always must rephrase to be understood. The High Intermediate (Level 3) English learner often fumbles for high frequency words and often must rephrase to be understood. The Advanced (Level 4) English learner rarely fumbles for high frequency words and occasionally must rephrase 
to be understood., while the Independent (Level 5) English learner uses vocabulary comparable to a native speaker within relevant contexts.

In reading, the Novice (Level 1) English learner comprehends simple short English sentences that contain familiar vocabulary, spelling patterns, and topics. The Low Intermediate (Level 2) English learner comprehends simple short sentences with a greater number of conceptually related words. The High Intermediate (Level 3) and the Advanced (Level 4) English learner comprehends longer selections containing high frequency and contextually relevant words. The Independent (Level 5) English learner comprehends text comparable to a native speaker.

\section{World-Class Instructional Design and Assessment Stages}

A resource that provides educators with tools to design and implement lessons that assist with the acquisition of academic language to English learners as it relates to their language proficiency level is the World-Class Instructional Design and Assessment (WIDA) Consortium's the English Language Learner Can Do Booklet (2012). WIDA has also developed standards known as the World-Class Instructional Design and Assessment (WIDA) English Language Development (ELD) Standards. These standards have been adopted by the state of Florida to support the language development of linguistically diverse learners. WIDA's Can DO Philosophy involves "believing in the assets, contributions, and potential of linguistically diverse students" (2012, np).

WIDA (2012) describes the following six stages of English language development: Entering, Beginning, Developing, Expanding, Bridging, and Reaching. In the Entering (Level 1) and Beginning (Level 2) stages, English learners' oral language contains grammatical errors that often impede meaning. In these first two stages, English 
learners develop from orally using words to short sentences. In the Developing (Level 3) stage, English learners' grammatical errors may impede the communication, but now much of its meaning is retained. The Developing English learner begins to expand sentences and has general and some specific language of the content areas.

WIDA (2012) describes the English learners in the Expanding (Level 4) stage as making minimal grammatical errors and these errors do not impede the overall meaning. The Expanding English learner uses a variety of sentence lengths of varying linguistic complexity and contains specific and some technical language of the content areas. In the Bridging (Level 5) and Reaching (Level 6) stage, English learners' oral or written language is moving from approaching to comparable to that of English-proficient peers. The Bridging and Reaching English learner use a variety of sentence lengths for oral or written discourse as required by the grade level and possesses specialized or technical language for the content area.

The World-Class Instructional Design and Assessment (WIDA) Consortium's the English Language Learner Can Do Booklet (2012) provides educators with descriptors of what English learners can do as it relates to their language development stage (Entering through Reaching) and the English / Language Arts standards (Listening, Speaking, Reading and Writing). With visual, graphic, or interactive support, English learners in the Entering (Level 1) stage can match icons or label pictures with words or concepts, identify cognates, make sound/symbol/word relations, communicate ideas by drawing, and answer oral questions with single words. In the Beginning (Level 2) stage, English learners can identify facts from illustrated text, find changes to root words, identify elements of story grammar, follow visually supported written directions, make lists, 
produce sentences from word banks, fill in graphic organizers, and make comparisons with supported materials.

According to the World Instructional Design and Assessment (WIDA) Consortium's the English Language Learner Can Do Booklet (2012), in the Developing (Level 3) stage, English learners can interpret information from charts, identify main ideas and details, sequence events or content-based processes, use context clues, produce simple expository or narrative text, string related sentences, compare/contrast contentbased information, and describe events, people, processes, procedures. In the Expanding (Level 4) stage, English learners can classify features of various genres of text, match graphic organizers to different texts, find details that support main ideas, differentiate between fact and opinion, take notes using graphic organizers, summarize content-based information, use writing models, and explain strategies in solving problems. In the Bridging (Level 5) stage, English learners summarize information from multiple sources, answer analytical questions, work with figures of speech, draw conclusions, produce extended responses, apply content-based information, make personal connections with literature or content, and create grade level stories or reports.

\section{Instructional Support for English Learners}

The current study was appropriate for English learners with more developed English skills. The World Instructional Design and Assessment (WIDA) Consortium's the English Language Learner Can Do Booklet (2012) states that with visual, graphic, or interactive support English learners in Level 3 can identify main ideas and details, sequence events or content-based processes, use context clues, produce simple expository or narrative text, string related sentences, compare/contrast content-based information, 
and describe events, people, processes, procedures. According to WIDA (2012), English learners in Level 4, with visual, graphic, or interactive support, can match graphic organizers to different texts, find details that support main ideas, take notes using graphic organizers, summarize content-based information, use writing models, and explain strategies in solving problems. According to WIDA, English learners in Level 5, with visual, graphic, or interactive support, can answer analytical questions, draw conclusions, produce extended responses, apply content-based information, make personal connections with content, and create grade level stories or reports.

These characteristics influenced the development and implementation of the Reciprocal Mapping (Fine, 2004) approach in the current study. The Reciprocal Mapping approach incorporated a direct and explicit instructional design with scaffold and guided practice that leads to paralleling the author's model (Fine, 2004; Fine, 2005). The current study incorporated the following suggested instructional support for ELs: incorporating graphic organizers, focusing on vocabulary, summarizing, and linking new content with background knowledge.

\section{Adapting Reciprocal Mapping for English learners}

The current study included some additions to the Reciprocal Mapping (Fine, 2004) approach to meet the needs of English learners.

Background Knowledge. The modifications of this instructional design are related to building the English learners' background knowledge on the cognitive processes related to text structures. The specific structures found in text are not limited to text; "they are rhetorical structures that reflect universal cognitive processes" (Williams, 2005, p. 7). These universal cognitive processes are reflective in the thinking of children 
such as comparing objects and situations or determine casual links in events. According to Williams (2005), the goal of teaching text structure is to assist the students in recognizing and matching these text structures to cognitive structures in order to understand and produce text and spoken discourse.

In order to build the English learners' background knowledge on these cognitive processes, the instructional design included a short activity that required the students to experience the cognitive process. For example, prior to studying the compare-contrast text structure, the students orally compare and contrast a common item. The teacher modeled the spoken discourse necessary to complete this task; i.e., using the compare and contrast signal words. In addition, the teacher assisted the students in making connections by asking them to share when they had to compare and contrast at home or in the community. The teacher scaffolded the students into making these connections by providing personal examples of when she had to compare and contrast; for example, buying cereal. This idea of having the students contribute their experiences as it relates to the topic is supported by the World-Class Instructional Design and Assessment (WIDA) English Language Development (ELD) Standards. These standards have been adopted by the state of Florida to support the language development of linguistically diverse learners. WIDA's Can DO Philosophy involves 'believing in the assets, contributions, and potential of linguistically diverse students" (np). The students later used their background knowledge of the cognitive structures to support their understanding of text structures.

Explicit Instruction with Feedback. There were two other instructional design modifications made to further support the needs of English learners. Williams (2005) 
argues that a structured and explicit approach is required to for students at risk for academic failure. The first modification involved providing an explicit explanation of the reading strategy and making a connection to the cognitive process just experienced. After the students "experience" the cognitive structure, the teacher explicitly explained the reading strategy (recognizing text structure to monitor reading comprehension) and connected the reading strategy to the cognitive process. The second modification involves providing independent practice with feedback. This modification is based on Williams' (2005) instructional design for teaching text structure. The teacher provided feedback as the English learners are applying the strategy. The students performed thinkalouds, so the teacher could provide feedback on the implementation of the strategy on new text.

Vocabulary. English learners will not only have difficulties comprehending text when the text has a high percentage of unknown words but will also not acquire new words from reading (Cervetti, Bravo, Duong, Hernandez, \& Tilson, 2008). The authors suggest providing special attention to vocabulary instruction and using content-area instruction as a context for the development of academic English. A review of vocabulary acquisition indicates that word learning is supported by vocabulary-rich reading with vocabulary instruction, repetition in meaningful contexts, using words orally or in writing, word analysis, and connections to first language (Cervetti, et.al, 2008).

The current study used science text as the context for the development of academic English, while including vocabulary instruction of signal words of the text structures and specific words of the science topic. The vocabulary words were practiced 
through oral and written summaries. Where appropriate, the vocabulary words were connected to the students' first language using Spanish cognates.

"Cognates are those words in Spanish and English that share the same etymology, have identical or nearly identical spelling, and have the same or similar meanings, depending on the context of their use" (Hernandez et al., 2016, p. 34). Cognates are commonly found in academic texts, therefore they might provide a powerful tool for bilingual students; however, these advantages have not been documented in research (Lubliner \& Hiebert, 2011). Kelley and Kohnert (2012) investigated the potential for a cognate advantage for processing vocabulary in Spanish-speaking English learners. Thirty Spanish-speaking English learners ranging in ages of 8- to 13-years old were given a standardized vocabulary tests in spoken English. The vocabulary words were classified as cognates and non-cognates. As a group, the participants' test scores were higher for the cognate items as compared to the non-cognate items. However, age was a significant predictor of the variance in cognate performance on the vocabulary test. Older children exhibited a higher instance of cognate advantage than younger children.

\section{Psychological Frameworks}

\section{Schema Theory}

Schema theory is "a theory about the structure of human knowledge as it is represented in memory" (Pearson, 2009, p.13). Schema theory explains how our prior knowledge influences how we understand new knowledge. A reader's schema assists in selecting, organizing, and summarizing the important information from the text, as well as making inferences. Schema theory uses a constructivist view of comprehension 
(sense-making) and suggests that comprehension occurs at the intersection of the reader, text, and context (Pearson, 2009).

Including the students' prior knowledge continues to be suggested when teaching comprehension. According to Goldenberg (2011), there is a significant research base on the impact of background knowledge in English learners reading comprehension. One suggestion on how to make lesson content more understandable to English learners is to use familiar content and linking new learning to the students' background and experience (Goldenberg, 2011).

\section{Metacognition}

An extension to schema theory and text analysis was developed to assist comprehension. Metacognition emphasizes procedural knowledge, which includes the strategies needed to "become aware of, monitor, evaluate, and repair our comprehension" (Pearson, 2009, p. 15). According to Griffith and Ruan (2005), learners that employ metacognition are able to "monitor and regulate their learning processes to accomplish the learning goals they set" (p. 16). The authors construct sample decisions a learner might need to apply while reading: when to reread, when and what type of inferences to create, how to select the most important information for retention, and adjust to an appropriate reading rate. According to Griffin and Ruan (2005), the purpose of metacognition instruction is to develop problem-solving readers equipped with a variety of task-specific reading strategies. Afflerbach, Pearson, and Paris (2008) state that "Reading strategies are deliberate, goal-directed attempts to control and modify the reader's efforts to decode text, understand words, and construct meanings of text" ( $p$. 368). The National Reading Panel report (National Institute of Child Health and Human 
Development [NICHD], 2000) also includes comprehension monitoring as one of the instructional strategies that have solid scientific foundation.

\section{Summary}

The current language arts standards require the students to think strategically and perform complex reasoning through informational text. According to Snow et al. (2002), reading comprehension is the process of simultaneously extracting and constructing meaning through interaction and involvement with written language. Comprehending informational text comes with its own challenges. According to Hall, Sabey, and McClellan (2005), informational texts "contain more unfamiliar vocabulary and concepts, fewer ideas related to the here-and-now, and less information directly related to personal experience" (p. 212). Reading strategies are found in many core reading programs, intervention programs, and instructional approaches. According to Afflerbach, Pearson, and Paris (2008), "Reading strategies are deliberate, goal-directed attempts to control and modify the reader's efforts to decode text, understand words, and construct meanings of text” (p. 368). The National Reading Panel (NRP) report (National Institute of Child Health and Human Development [NICHD], 2000) notes seven instructional strategies that have solid scientific foundation and are closely related to reading strategies and metacognition: comprehension monitoring, cooperative learning, use of graphic and semantic organizers, question answering, question generation, use of story structure, and summarization. There are specific reading strategies for the comprehension of information text. According to Weisberg (1990), recognizing text structure, constructing graphic organizers, and writing summaries are strategies that have helped students learn 
from informational text, especially when the students have limited prior knowledge on the topic.

The current study was designed to investigate how the development of third-grade students' knowledge of informational text structures, through the Reciprocal Mapping (Fine, 2004) approach, impacted their ability to comprehend informational text and reading attitude. Petscher (2010) indicates a moderate relationship between reading attitude and achievement is moderate and expresses the importance of further research on understanding how attitude may interact with other psychosocial constructs, and how reading attitude may be strengthened.

According to Akhondi, Malayeri, and Samad (2011), teaching text structures of expository texts may be an effective technique to improve reading comprehension and retention. Tompkins (1998) suggested the following three steps in teaching expository text structure: introduction of an organization pattern through signal words and graphic organizer, practice with analyzing text structures of texts, and use the different text structures to write paragraphs. Williams (2005) elaborates on the instructional design and includes introducing content in small increments, modeling, scaffolding, and practice with feedback. Reciprocal Mapping incorporates Tompkins' (1998) and Williams' (2005) instructional designs. This current study included the following suggested instructional components for teaching text structure: incorporating cognitive structures, signal words, graphic organizers, and Reciprocal Mapping.

Two studies that investigated the effectiveness of implementing text structure instruction for improving reading comprehension were discussed. In the first study, Williams et al. (2007), found that the overall effect of treatment on the students' ability to 
answering questions related to the structure of the text indicates that instruction in text structure impacts the students' ability to understand clauses in the text suggesting that teaching text structure is worthy of future study. In the second study, Hall et al. (2005), found that the overall effect of treatment on the students' ability to summarize a compare/contrast paragraph not seen during instruction indicates instruction in text structure transfers to other novel text suggesting that teaching text structure is worthy of future study. In addition, a meta-analysis that aimed to determine the effectiveness of text structure instruction across a range of participants and contexts was described (Hebert et al., 2016). This meta-analysis indicates that text structure instruction improves expository reading comprehension $(E S=0.57)$, including for students with or at-risk for disabilities. In addition, including more text structures and writing in the study were significant predictors of the effectiveness of the intervention.

Lastly, instructional support for English learners was discussed as it relates to comprehending informational text. The following instructional support suggestions were incorporated to further meet the needs of English learners: incorporating graphic organizers, focusing on vocabulary, summarizing, and linking new content with background knowledge. 


\section{CHAPTER III}

\section{METHODOLOGY}

The purpose of the study was to examine the effect of a comprehensive reading strategy approach, Reciprocal Mapping (Fine, 2004), on reading achievement and reading attitude of a sample of third grade students. The study contributes to the research on how to best develop ability to comprehend informational texts and how to strengthen reading attitude. The chapter includes the research design, the research questions and the hypotheses. In addition, details about the study's setting and participants, sampling procedures, instruments, variable list, treatment, data collection, statistical treatment, and limitations are provided.

\section{Design}

The investigator developed a pretest/posttest control group quasi-experimental design with the treatment (standards-based instruction and the Reciprocal Mapping approach) and the comparison group (standards-based instruction without the Reciprocal Mapping approach) as the independent variables. The first dependent variable was reading comprehension achievement on the second administration of the $i$-Ready Diagnostic and reading attitude on the Elementary Reading Attitude Survey (McKenna \& Kear, 1990) as the second dependent variable.

\section{Research Questions}

Question 1: Is there a difference in reading comprehension levels of third-grade students taught with standards-based instruction on science informational text with the Reciprocal Mapping (Fine, 2004) approach than third-grade students taught with standards-based instruction without the Reciprocal Mapping approach? 
Question 2: Is there a difference in reading attitude of third-grade students taught with standards-based instruction with the Reciprocal Mapping (Fine, 2004) approach than third-grade students taught with standards-based instruction without the Reciprocal Mapping approach?

\section{Hypotheses}

Hypothesis 1: Third-grade students taught using standards-based instruction on science informational text with the Reciprocal Mapping (Fine, 2004) approach will achieve significantly higher mean scores on the second administration of the i-Ready Diagnostic assessment than the students taught using standards-based instruction without the Reciprocal Mapping approach.

Hypothesis 2: Third-grade students taught with standards-based instruction on science informational text with the Reciprocal Mapping (Fine, 2004) approach will achieve significantly higher mean scores for their responses to the second administration of the Elementary Reading Attitude Survey than the students taught with standards-based instruction without the Reciprocal Mapping approach.

\section{Setting and Participants}

The setting was an urban K-5 school in a large school district in the southern part of Florida. The researcher met with the school's principal to explain the study and acquire permission to conduct the study at the school. The participants were 100 thirdgrade students and four science teachers. Fifty-six of the participants have an ESOL functional level of III, IV, V. 


\section{School}

The participating urban K-5 school is considered a Title I school, indicating that most the school population $(80.3 \%)$ qualifies for free-or reduced lunch. Most the school population consists of Hispanic students $(95.8 \%)$. Of the total school population, about $47 \%$ of the students are English learners.

\section{Teachers}

Four teachers from the participating urban K-5 school assisted in this study. The four teachers are of Hispanic backgrounds and on average have about 15 years of teaching experience. The researcher approached the third-grade level chairperson to find out when the next grade level meeting was going to be held. The researcher asked permission to attend the grade-level meeting to explain and recruit for the study. The date and permission were provided. The researcher attended a third-grade level meeting to explain the study and recruit teachers for the study. The explanation and recruitment took 20 minutes. The teachers participated in training sessions describe in detail below.

\section{Students}

The researcher sent a letter to the parents of the third-grade students of the school, except for students with an ESOL functional level of I or II, inviting them to an informational meeting about the study. During the meeting, the study was explained, and permission was acquired for participation (see Appendix A). The permission form for the study was sent home with the students of the families that did not attend the meeting. The permission form was written in English and Spanish and contained the researcher's contact information if they had questions. 
There were 100 students participating in the study. Fifty-six of the English learners had an ESOL functional level of III, IV, V. Students working at an ESOL functional level I or II were not included in the study because of their limited English vocabulary.

\section{Sampling Procedures}

The participants were selected through established classrooms. The students were randomly assigned to the classrooms by the second-grade teachers during the end-of-theyear articulation meeting. The pre-established third-grade classrooms were randomly assigned to the treatment or comparison group. An online random group creator was used to randomly assign the six groups into the treatment or comparison group.

\section{Instruments}

The i-Ready Diagnostic was used to measure the participants' reading comprehension achievement. The first administration of the i-Ready Diagnostic was used as the pretest to measure reading comprehension before the study's treatment. The second administration of the $i$-Ready Diagnostic was used as the posttest to measure reading comprehension after the study's treatment. According to Curriculum and Associates (n.d.), the development of the diagnostic passages followed the recommendations from the Common Core State Standards that readability be evaluated both quantitatively and qualitatively. The quantitative tools used when developing the iReady passages were the Lexile and Flesch-Kincaid to properly determine readability levels. Subject matter experts determined the passages' appropriateness for Reader and Task complexity. According to Curriculum and Associates (n.d.), recent independent research indicated that i-Ready Diagnostic is highly correlated to the Common Core state 
assessments. According to Curriculum and Associates, a strong overall correlation of 0.85 for English Language Arts was found between the spring i-Ready Diagnostic and the 2015 New York State Common Core Assessments.

The Elementary Reading Attitude Survey (McKenna \& Kear, 1990) was used to measure the participants' reading attitude. The first administration of the Elementary Reading Attitude Survey (McKenna \& Kear, 1990) was used as the pretest to measure reading attitude before the study's treatment. The second administration of the Elementary Reading Attitude Survey (McKenna \& Kear, 1990) was used as the posttest to measure reading attitude after the study's treatment. The reliability estimates for the two subscales and for the composite score use Cronbach's alpha. The coefficients range from .74 to .89 , and 16 out of 18 coefficients were at least .80 (McKenna, et al., 1995).

Evidence of construct validity was established through a series of tests in which subjects were grouped by criterial variables. The recreational subscale was tested with groups with and without library cards and with and without a book currently checked out. The academic subscale was tested with grouping the children on reading ability. Additional evidence of validity was established through two factor analyses. These analyses used the unweighted least squares method of extraction and a varimax rotation.

\section{Variable List}

The following list represents how the variables were coded in the present study. The independent variable:

Group ( 1 = Standards-based Instruction with the Reciprocal Mapping approach; $2=$ Standards-based Instruction without Reciprocal Mapping approach) 
The dependent variables:

PostReading

PostAttitude

\section{Treatment}

\section{Materials}

The development of the materials used in the study involved many factors. The researcher used the school district's pacing guide to determine the science standards that were to be taught during the time of the study. The pacing guide indicated that the topic of energy was to be studied during the time of the study. Using the pacing guide, the researcher determined the specific science standards involved with the study of energy for students in third grade. Then the researcher found text that not only aided the study of the science topic but also followed the reading text structure that was to be studied. The treatment group used these informational passages on the topic being studied in science (see Appendix B). The researcher adapted the passages to include signal words. These texts were used to complete the Reciprocal Mapping (Fine, 2004) approach. A PowerPoint presentation was provided to the teachers to guide them through the text structure lessons and to keep consistency of instruction between the different teachers (see Appendix C). The Reciprocal Mapping template was provided to the teachers for each text structure (see Appendix D). The selection of the materials and instructional strategies allowed the teachers to tackle the science standards within the reading standards. 


\section{Teacher Training Method}

The teachers were trained through a face-to-face professional development during their combined planning time. The training included information about the study, materials, and methods. The teachers observed a lesson being taught by the researcher. Lastly, the teachers modeled the sequence of a lesson with each other. In addition, the researcher explained how The Elementary Reading Attitude Survey (McKenna \& Kear, 1990) was to be administered. The training took place during two separate one-hour planning periods. The researcher performed two observations of the teacher conducting the experiment with the participating students. Further training was not necessary, as the teachers were effectively conducting the lessons. The researcher provided a detailed script for the teachers to follow. The teachers followed the script during the duration of the treatment.

\section{Intervention Routine}

The intervention routine began with the pre-tests. Weeks 1 and 2 were needed to complete both pre-tests. The first administration of the reading $i$-Ready Diagnostic was administered to all the participants through the computer. The students went to the computer lab and completed the reading comprehension test. The Elementary Reading Attitude Survey (McKenna \& Kear, 1990) was administered in the classroom by the classroom teacher. Weeks 3 through 10 were dedicated for the implementation of the treatment (see Table 3). 
Table 3

Intervention Schedule

\begin{tabular}{cc}
\hline Week & Focus \\
\hline $1-2$ & Reading Pre-Test: -Ready Diagnostic \\
4 & Reading Attitude Pre-Test: The Elementary Reading Attitude Survey \\
5 & Text Structure: Description \\
6 & Text Structure: Sequence \\
7 & Text Structure: Compare and Effect \\
8 & Text Structure: Problem Solution \\
9 & Text Structure: Review Description, Sequence, and Cause and Effect \\
10 & Text Structure: Review Compare and Contrast and Problem Solution \\
$11-12$ & Reading Post Test: $i$-Ready Diagnostic \\
& Reading Attitude Post Test: The Elementary Reading Attitude Survey \\
\hline
\end{tabular}

According to Weisberg (1990), recognizing text structure, constructing graphic organizers, and writing summaries are strategies that have helped students learn from informational text, especially when the students have limited prior knowledge on the topic. According to Grabe (2009), attention to text structure can enhance the literacy development of English learners. Reciprocal Mapping was incorporated into the treatment. Reciprocal Mapping incorporates Weisberg's (1990) suggestion of recognizing text structure and constructing graphic organizers as strategies for learning from informational text. However, Reciprocal Mapping allows the students to use the text's structure to develop their own writing.

Each week the teachers in the treatment group focused on one of the five text structures. Both the treatment and comparison group received a short passage on the science topic and text structure to be studied in the week. The weekly routine was constant for each text structure (see Table 4). The teacher developed background knowledge of the cognitive structures with a quick interactive scenario. The interactive scenario incorporated the students' background and experiences. For example, when 
studying the sequence text structure, the students can sequence the steps of how to play their favorite game.

Then the teacher proceeded with the Reciprocal Mapping (Fine, 2004) approach for teaching the specific text structure. The text was analyzed for its structure by looking for signal words and completing a graphic organizer. Special attention was given to important vocabulary and cognates. The students then used the completed graphic organizer to write a summary of the text. Lastly, the students answered comprehension questions of the text. The sequence of these activities per text structure was conducted in three sessions of 30 minutes each per week. The teacher had a log of planned activities that they noted when completed. In addition, the teachers provided the researcher with the completed artifacts of the study. These artifacts include the completed Reciprocal Mapping templates and science passages.

Table 4

Intervention Routine for Treatment Group

\begin{tabular}{cc}
\hline Slide & Activity \\
\hline $1-2$ & $\begin{array}{c}\text { Explain purpose of lesson } \\
\text { Review definition of a strategy and reading comprehension } \\
\text { Review definition of nonfiction text } \\
\text { Review what is text structure }\end{array}$ \\
$4-5$ & $\begin{array}{c}\text { Review previously studied text structures with chart } \\
\text { Explicitly explain new text structure with definition, corresponding graphic } \\
\text { organizer, example of matching cognitive structure, and signal words }\end{array}$ \\
6 & $\begin{array}{c}\text { Students conduct cognitive structure related to text structure } \\
7\end{array}$ \\
8 & Begin Reciprocal Mapping with vocabulary and cognates \\
9 & Read the text and guide students in finding signal words \\
10 & Guide the completion of the graphic organizer on the Reciprocal Map \\
11 & Guide the determination of the text structure and key concept on Reciprocal \\
& The students answer the text's comprehension questions. \\
& The teacher provides the answers to the questions.
\end{tabular}




\section{Comparison Group}

The comparison group used the same informational passages on the topic being studied in science. However, a standards-based instruction without the Reciprocal Mapping (Fine, 2004) approach was implemented with the control group. The teachers did not discuss the text's structure. Instead, the teachers discussed the topic through the comprehension questions provided by the passage. The students read the text individually and answered the comprehension questions. Then the teacher and students read and discussed the passage together. Lastly, the answers to the comprehension questions were provided by the teacher. The teacher had a log of planned activities that they needed to note if completed. In addition, the teachers provided the researcher the completed science passages.

\section{Data Collection}

The first administration of the $i$-Ready Diagnostic was administered as the pretest to establish the students' reading comprehension level before the treatment. The second administration of the $i$-Ready Diagnostic was administered as the posttest to determine the students' reading comprehension level after the treatment. The first and second administration of the $i$-Ready Diagnostic was used to determine whether third-grade students taught using standards-based instruction on science informational text and the Reciprocal Mapping (Fine, 2004) approach achieved significantly higher mean scores than third-grade students taught using standards-based instruction without the Reciprocal Mapping strategy. The first and second administration of the $i$-Ready Diagnostic was administered individually on the computer in the computer lab with teacher supervision. The $i$-Ready Diagnostic reports were gathered by the teacher and researcher. 
After the students completed the first administration of the i-Ready Diagnostic, the first administration of the Elementary Reading Attitude Survey (McKenna \& Kear, 1990) was administered. The first administration of the Elementary Reading Attitude Survey (McKenna \& Kear, 1990) served as the pretest to establish the students' reading attitude before the treatment. The second administration of the Elementary Reading Attitude Survey (McKenna \& Kear, 1990) was administered as the posttest to determine the students' reading attitude after the treatment. The first and second administration of the Elementary Reading Attitude Survey (McKenna \& Kear, 1990) was used to determine whether third-grade students taught using standards-based instruction on science informational text and the Reciprocal Mapping strategy achieved significantly higher mean scores than the students' taught using standards-based instruction without the Reciprocal Mapping strategy. The first and second administration of the Elementary Reading Attitude Survey (McKenna \& Kear, 1990) was administered to all the students at the same time by the teacher. The teacher explained the pictures and read the questions aloud to the students. The students marked on their individual paper test. The researcher gathered and scored the surveys.

\section{Statistical Treatment}

Using the general linear model, a univariate ANCOVA was conducted to determine group differences (treatment and comparison) as it relates to mean reading scores on the second administration of the $i$-Ready Diagnostic. The post reading score was the dependent variable, group membership (treatment or control) was the independent variable, and the pre-test reading scores were the covariate. 
The same statistical treatment was used to determine group differences (treatment and comparison) as it relates to mean reading attitude scores on the second administration of the Elementary Reading Attitude Survey (McKenna \& Kear, 1990). Using the general linear model, a univariate ANCOVA was conducted. The post reading attitude score was the dependent variable, group membership (treatment or control) was the independent variable, and the pre-test reading attitude scores were the covariate.

\section{Limitations}

One major limitation to the current study. The start of the treatment was delayed due to a major factor. This factor was the impact of a major hurricane closing the schools for two weeks. The participants were to have been completing their pre-tests during these weeks. The administration of the pre-tests was given after schools re-opened; therefore, the treatment did not begin until three weeks after the original start date.

The first administration of the i-Ready Diagnostic served as the pre-test that measured reading comprehension. The second administration of the i-Ready Diagnostic served as the posttest. The $i$-Ready Diagnostic is a computerized reading test provided by the school district. The school district provides a window on when these tests need to be given and did not extend the administration dates of the second administration of the test. Therefore, the treatment time had to be reduced from 10 weeks of intervention to 7 weeks.

The teachers were originally scheduled to teach each of the five text structures twice in ten weeks. However, due to the need to meet district's requirements of administrating the second $i$-Ready Diagnostic, the teachers taught each of the five text 
structures once in five weeks and the last two weeks were a review of all five text structures.

Another limitation to the current study is that the study examined one group of third grade students from one school. The participants in the study all attend the same school. Another limitation of the study involves the fidelity of the implementation of the study. The teachers in the study, not the researcher, implemented the treatment. The researcher observed the teachers and gathered the artifacts of the study to assist with the fidelity of the implementation of the treatment.

\section{Summary}

The purpose of the study was to examine the effect of a comprehensive reading strategy approach, Reciprocal Mapping (Fine, 2004), on reading achievement and reading attitude of a sample of third grade students. The specific research questions and hypotheses were provided. The researcher developed a pretest/posttest control group quasi-experimental design with the treatment (standards-based instruction and the Reciprocal Mapping approach and standards-based instruction without the Reciprocal Mapping approach) as the independent variable and reading comprehension achievement on the second administration of the i-Ready Diagnostic as the first dependent variable and reading attitude on the second administration of the Elementary Reading Attitude Survey (McKenna \& Kear, 1990) as the second dependent variable.

The current study's setting, participants, and methods were described. The proposed statistical treatment was described. 
Using the general linear model, a univariate ANCOVA was conducted to determine group differences as it relates to reading comprehension, as measured on the $i$-Ready Diagnostic, and reading attitude, as measured on the Elementary Reading Attitude Survey, when controlling for pretest. Lastly, the study's limitations were described. 


\section{CHAPTER IV}

\section{RESULTS}

The purpose of the study was to examine the effect of a comprehensive reading strategy approach, Reciprocal Mapping (Fine, 2004), on reading achievement and reading attitude of a sample of third grade students. The investigator developed a pretest/posttest control group quasi-experimental design with the treatment (standards-based instruction and the Reciprocal Mapping approach) and the comparison group (standards-based instruction without the Reciprocal Mapping approach) as the independent variables. The first dependent variable was reading comprehension achievement on the second administration of the $i$-Ready Diagnostic and reading attitude on the Elementary Reading Attitude Survey (McKenna \& Kear, 1990) as the second dependent variable. The chapter includes the overall description of the data and the results of the hypotheses.

\section{Overall Description of the Participants}

There were 100 participants in the current study. Of these participants, 98 were Hispanic and 2 were considered diverse, but non-Hispanic. There were 58 male students and 42 students were female. Of the 100 participants, 56 of the participants had an ESOL function level III, IV, or V. There were a total of 11 students with disabilities. All the participants were placed in one of two groups, the treatment group or the control group. There were 51 participants in the treatment group and 49 participants in the control group. 
Table 5

Group Demographics $(N=100)$

\section{Group}

\begin{tabular}{llc}
\cline { 2 - 3 } Demographic & Treatment & Control \\
\hline Participants & 51 & 49 \\
Hispanic & 46 & 49 \\
English Speaker of Other Languages (ESOL) & 19 & 37 \\
Males & 27 & 31 \\
Females & 24 & 18 \\
\hline
\end{tabular}

\section{Results of the Study}

The current study examined the following:

1. The effects of the Reciprocal Mapping (Fine, 2004) approach on third-grade students' ability to comprehend informational text.

2. The effects of the Reciprocal Mapping (Fine, 2004) approach on third-grade students' reading attitude.

Specifically, the following research questions were addressed in this study:

Question 1: Is there a difference in reading comprehension levels of third-grade students taught with standards-based instruction on science informational text with the Reciprocal Mapping (Fine, 2004) approach than third-grade students taught with standards-based instruction without the Reciprocal Mapping approach?

Question 2: Is there a difference in reading attitude of third-grade students taught with standards-based instruction with the Reciprocal Mapping (Fine, 2004) approach than 
third-grade students taught with standards-based instruction without the Reciprocal Mapping approach?

The following hypotheses were used in this study:

Hypothesis 1: Third-grade students taught using standards-based instruction on science informational text with the Reciprocal Mapping (Fine, 2004) approach will achieve significantly higher mean scores on the second administration of the $i$-Ready Diagnostic assessment than the students taught using standards-based instruction without the Reciprocal Mapping approach.

Hypothesis 2: Third-grade students taught with standards-based instruction on science informational text with the Reciprocal Mapping (Fine, 2004) approach will achieve significantly higher mean scores for their responses to the second administration of the Elementary Reading Attitude Survey than the students taught with standards-based instruction without the Reciprocal Mapping approach.

The results of the i-Ready Diagnostic and the Elementary Reading Attitude Survey were analyzed to determine whether there was a significant difference of post reading and reading attitude scores of the two groups. Group difference in reading comprehension on the $i$-Ready Diagnostic was analyzed to answer the following question:

Question 1: Is there a difference in reading comprehension levels of third-grade students taught with standards-based instruction on science informational text with the Reciprocal Mapping (Fine, 2004) approach than third-grade students taught with standards-based instruction without the Reciprocal Mapping approach?

Descriptive statistics for post reading scores indicate the following: Treatment $n$ $=51, M=550.63, S D=37.97 ;$ Control $n=49, M=495.00, S D=47.08$. The Levene's 
test for equality of variance was used to determine group differences as it relates to the pre-test in reading. The Levene's test indicated that the groups were not significantly different as it relates to the reading pre-test: $F(1,98)=1.14, p=.289$.

Using the general linear model, a univariate ANCOVA was conducted. The post reading score was the dependent variable, group membership (treatment or control) was the independent variable, and the pre-test reading scores were the covariate. The results of the univariate ANCOVA indicated that there was a significant difference for overall reading comprehension between the two groups when controlling for the pre-test scores $F(1,97)=16.46, p=.000$. Table 6 indicates the results adjusted for the covariate, reading pre-test scores.

Table 6

Group Differences of Post Reading Adjusted by Pre-test Score

\begin{tabular}{lllc}
\hline Group & Mean & \multicolumn{2}{c}{$95 \%$ Confidence Interval } \\
\cline { 3 - 4 } & & Lower Bound & Upper Bound \\
\hline Treatment & 535.64 & 527.48 & 543.81 \\
Control & 510.60 & 502.25 & 518.94 \\
\hline
\end{tabular}

The students' ESOL levels were also analyzed by conducting a univariate ANCOVA. The post reading score was the dependent variable, group membership (treatment or control) was the independent variable, and the students' ESOL levels were the covariate. The results of the univariate ANCOVA indicated that there was a significant difference for overall reading comprehension between the two groups when controlling for the ESOL level $F(1,97)=16.03, p=.000$. Table 7 indicates the results adjusted for the covariate, ESOL membership. 
Table 7

Group Differences of Post Reading Adjusted by ESOL Membership

\begin{tabular}{llll}
\hline Group & Mean & \multicolumn{2}{c}{$95 \%$ Confidence Interval } \\
\cline { 3 - 4 } & & Lower Bound & Upper Bound \\
\hline Treatment & 541.61 & 529.59 & 553.64 \\
Control & 504.38 & 492.08 & 516.69 \\
\hline
\end{tabular}

Third-grade students taught using standards-based instruction on science informational text with the Reciprocal Mapping (Fine, 2004) approach achieved significantly higher mean scores on the second administration of the i-Ready Diagnostic assessment than the students taught using standards-based instruction without the Reciprocal Mapping approach. Significance was also achieved when adjusting for reading pre-test scores and ESOL membership.

To measure the difference of reading attitude levels between the treatment and the control group (Question 2), both groups were given the first administration of the Elementary Reading Attitude Survey as the reading attitude pre-test and the second administration of the Elementary Reading Attitude Survey as the reading attitude posttest. The Elementary Reading Attitude Survey (McKenna \& Kear, 1990) was administered to all the students at the same time by the classroom teacher. The teacher explained the possible responses and read each of the items on the survey. The survey measures the attitude of the students towards recreation and academic reading. Group difference in reading attitude on the Elementary Reading Attitude Survey was analyzed to answer the following question: 
Question 2: Is there a difference in reading attitude of third-grade students taught with standards-based instruction with the Reciprocal Mapping (Fine, 2004) approach than third-grade students taught with standards-based instruction without the Reciprocal Mapping approach? Using the general linear model, a univariate ANCOVA was conducted. The post reading attitude score was the dependent variable, group membership (treatment or control) was the independent variable, and the pre-test reading attitude scores were the covariate.

Descriptive statistics for post reading attitude scores indicate the following: Treatment $n=51, M=60.53, S D=9.85$; Control $n=49, M=55.61, S D=11.36$. The Levene's test for equality of variance was used to determine group differences as it relates to the pre-test in reading attitude. The Levene's test indicated that the groups were not significantly different as it relates to the reading attitude pre-test: $F(1,98)=$ 1.68, $p=.199$. Using the general linear model, a univariate ANCOVA was conducted. The results of the univariate ANCOVA indicated that there was not a significant difference for overall reading attitude between the two groups based on the post reading attitude test scores when controlling for the pre-test scores $F(1,97)=.060 p=.807$. 


\section{Summary}

Chapter 4 described the data analyses of the results of this study. The purpose of the study was to examine the effect of a comprehensive reading strategy approach, Reciprocal Mapping (Fine, 2004), on reading achievement and reading attitude of a sample of third grade students. A pretest/posttest control group quasi-experimental design was implemented. The instruments used to determine group differences in reading comprehension and reading attitude were described. The type of statistical analyses were provided. The overall description of the data and the results of the hypotheses were explained. The ANCOVA conducted indicated that there was a significant difference for overall reading comprehension between the two groups based on the post reading test scores when controlling for the pre-test scores and ESOL membership. However, there was not a significant difference for overall reading attitude between the two groups based on the post reading attitude test scores. 


\section{CHAPTER V \\ CONCLUSIONS AND IMPLICATIONS}

The purpose of the study was to examine the effect of a comprehensive reading strategy approach, Reciprocal Mapping (Fine, 2004), on reading achievement and reading attitude of a sample of third grade students. A pretest/posttest control group quasiexperimental design was implemented. The treatment group received standards-based instruction with the Reciprocal Mapping (Fine, 2004) approach. The control group received standards-based instruction without the Reciprocal Mapping approach. This chapter includes a summary of the current study's findings. The implications of these findings and recommendations for research will be discussed. Lastly, a summary will be included.

\section{Summary of the Findings}

A decrease in reading achievement is evident as early as fourth grade due to demands of reading intermediate text (Williams et al., 2005). The National Assessment of Educational Progress (NAEP) states that only $37 \%$ of fourth graders are proficient on the reading assessment (U.S. Department of Education, 2018). According to the Florida Department of Education (FLDOE), the Language Arts Florida Standards (LAFS) require a 50-50 balance between informational and literary reading in the elementary grades. The requirements of the state standards combined with the challenges of reading information text leads to a need to research instructional methods that might increase reading achievement.

The current study aimed to contribute to the research, specifically it investigated the effects of the Reciprocal Mapping (Fine, 2004) approach on third-grade students' 
reading comprehension achievement and reading attitude. The following research questions were addressed in this study:

Question 1: Is there a difference in reading comprehension levels of third-grade students taught with standards-based instruction on science informational text with the Reciprocal Mapping (Fine, 2004) approach than third-grade students taught with standards-based instruction without the Reciprocal Mapping approach?

Question 2: Is there a difference in reading attitude of third-grade students taught with standards-based instruction with the Reciprocal Mapping (Fine, 2004) approach than third-grade students taught with standards-based instruction without the Reciprocal Mapping approach?

A pretest/posttest control group quasi-experimental design was used to investigate the possible effects of the Reciprocal Mapping (Fine, 2004) approach on third-grade students' reading comprehension achievement and reading attitudes.

There were 100 participants in the current study. Of these participants, 95 were Hispanic and 5 were considered diverse, but non-Hispanic. There were 58 male students and 42 students were female. Of the 100 participants, 56 of the participants had an ESOL function level III, IV, or V. All the participants were placed in one of two groups, the treatment group or the control group. There were 51 participants in the treatment group and 49 participants in the control group. The treatment group received standards-based instruction and the Reciprocal Mapping (Fine, 2004) approach, while the comparison group received standards-based instruction without the Reciprocal Mapping approach.

The treatment group analyzed the structure of text through the Reciprocal Mapping (Fine, 2004) approach to increase reading comprehension. Reciprocal Mapping 
is a comprehension strategy which combines several evidenced-based strategies to identify text structure and use graphic organizers to be able to write about a topic. Students identify and include evidence from text, add prior related knowledge and key vocabulary, and then write original summaries of the information.

The comparison group used the same informational passages on the topic being studied in science. However, a standards-based instruction without the Reciprocal Mapping (Fine, 2004) approach was implemented with this group. The teachers did not discuss the text's structure. Instead, the teachers discussed the topic through the comprehension questions provided by the passage. The teacher and students read and discussed the passage together with the support of the comprehension questions.

To measure the difference of reading comprehension levels between the treatment and the control group (Question 1), both groups were given the first administration of the i-Ready Diagnostic as the reading comprehension pre-test and the second administration of the i-Ready Diagnostic as the reading comprehension posttest. Using the general linear model, a univariate ANCOVA was conducted. The post reading score was the dependent variable, group membership (treatment or control) was the independent variable, and the pre-test reading scores were the covariate. This analysis indicated that there was a significant difference for overall reading comprehension between the two groups based on the post reading test scores when controlling for the pre-test scores $F(1$, 97) $=16.46, p=.000$.

The second covariate analyzed through a univariate ANCOVA was ESOL membership. The post reading score was the dependent variable, group membership (treatment or control) was the independent variable, and whether the students were ESOL 
was the covariate. The results of the univariate ANCOVA indicated that there was a significant difference for overall reading comprehension between the two groups when controlling for the ESOL membership $F(1,97)=16.03, p=.000$.

To measure the difference of reading attitude levels between the treatment and the control group (Question 2), both groups were given the first administration of the Elementary Reading Attitude Survey as the reading attitude pre-test and the second administration of the survey as the reading attitude posttest. Using the general linear model, a univariate ANCOVA was conducted. The post reading attitude score was the dependent variable, group membership (treatment or control) was the independent variable, and the pre-test reading attitude scores were the covariate. This analysis indicated that there was not a significant difference for overall reading attitude between the two groups based on the post reading attitude test scores when controlling for the pretest scores $F(1,97)=.060 p=.807$.

\section{Implications}

The findings suggest that standards-based instruction on science informational text with the Reciprocal Mapping (Fine, 2004) approach was an effective method for increasing third-grade students' reading comprehension. This study supports earlier research of the effectiveness of incorporating the study of text structure to enhance English Learners' literacy development (Grabe, 2009). In addition, the findings support the notion that recognizing text structure, constructing graphic organizers, and writing summaries assist students in learning from informational text (Weisber, 1990), which are the components of Reciprocal Mapping. 
Lastly, this study took careful consideration incorporating instructional modifications that support the needs of English learners. According to Goldenberg (2011), English learners may require additional instructional modifications primarily due to their limited proficiency in English. The current study adapted the Reciprocal Mapping (Fine, 2004) approach to incorporate the following suggested instructional support for ELs: incorporating graphic organizers, focusing on vocabulary, summarizing, and linking new content with background knowledge. The two major English learner instructional supports involved building background knowledge and vocabulary.

The ELs' background knowledge of the cognitive structures was developed. According to Williams (2005), the goal of teaching text structure is to assist the students in recognizing and matching these text structures to cognitive structures to understand and produce text and spoken discourse. These universal cognitive processes are reflective in the thinking of children such as comparing objects and situations or determine casual links in events. In the current study, the ELs in the treatment developed an understanding of these cognitive structures and connected them to the structures of text.

The second major English learner instructional support involved building vocabulary, specifically the use English-Spanish cognates. English learners will not only have difficulties comprehending text when the text has a high percentage of unknown words but will also not acquire new words from reading (Cervetti, et.al, 2008). The authors suggest using content-area instruction as a context for the development of academic English and using connections to first language for vocabulary acquisition. The current study incorporated vocabulary-rich reading with vocabulary instruction 
through science text. These vocabulary words were practiced through oral and written summaries. In addition, where appropriate, the vocabulary words were connected to the students' first language through English-Spanish cognates. "Cognates are those words in Spanish and English that share the same etymology, have identical or nearly identical spelling, and have the same or similar meanings, depending on the context of their use" (Hernandez et al., 2016, p. 34).

The group difference was not significant when analyzing for reading attitude. These findings are congruent with previous research on reading attitude. According to McKenna et al. (1995), attitude towards reading both for recreational and academic grew increasingly negative as students moved from first to sixth grade, with larger declines in academic reading attitudes. Reading attitudes in Grade 1 begin relatively positive and

end in relative indifference by Grade 6. When analyzing for reading attitude and ability, the authors indicate significant main effects of a reader's history of success or frustration and its role in shaping reading attitude. In academic reading attitude the negative trend is not related to reading ability.

\section{Recommendations for Research}

The Reciprocal Mapping (Fine, 2004) approach with instructional modifications for English learners can serve as an instructional design for increasing reading comprehension of informational text in the reading and content area classroom. The first recommendation for future research would be to increase the treatment time to study each of the five text structures twice. During the second opportunity to develop the specific text structure, the teacher might be able to gradually release responsibility and provide more opportunities for student practice and application. 
The second recommendation for future research involves adapting the current study's instructional design to meet the needs of primary students. A decrease in reading achievement is evident as early as fourth grade due to demands of reading intermediate text (Williams et al., 2005). The current study was implemented with third-grade students to assist with this reading decline. However, future research on increasing reading comprehension of informational text should not begin at third-grade. Therefore, how can this study's instructional design be incorporated into the primary classroom to investigate the effectiveness of the design towards primary students' reading comprehension?

The third recommendation for future research involves investigating the possible effects of the treatment towards science achievement. The study incorporated reading strategies into the content area of science to increase reading achievement. A future study could incorporate the investigation of science achievement. Do the students receiving the treatment exhibit higher mean scores on the science unit test that correlates with the topics studied?

The last recommendation for future research involves investigating possible predictors of reading attitude. The treatment in the current study did not significantly influence reading attitudes. More research is needed to investigate methods of increasing reading attitude with diverse students. A possible influence of changing attitude is time. A possible future question is whether more time receiving the treatment will influence a change in attitude. The study focused on reading attitude. An extension to the concept of attitude would be to investigate the treatment's effect towards the students' science attitude. Does implementing the Reciprocal Mapping (Fine, 2004) approach through 
science informational text influence the students' science attitudes? In addition, future studies can focus on teacher's perceptions or attitude towards teaching science in general or through an integrated science and reading approach.

\section{Summary}

Chapter 5 summarized the current study's findings, provided the implications of the study, and offered recommendations for future research. The study examined the effect of a comprehensive reading strategy approach, Reciprocal Mapping (Fine, 2004), on reading achievement and reading attitude of a sample of third grade students. The statistical analyses of the results indicated that there was a significant difference for overall reading comprehension between the treatment and control group. There was not a significant difference for overall reading attitude between the treatment and control groups.

Teachers have the critical task of supporting students' reading development of informational text. Students, including English learners face stringent consequences when performing poorly on state assessments, such as retention or failing to graduate from high school. The demands on students, including English learners, compounded with the demands of the state's standards and assessments offer great challenges for teachers and students. There is a need to research instructional methods that might increase reading achievement. The current study contributes to the research base of instructional methods for increasing reading comprehension of third-grade students, including English learners.

Practitioners can use the study's instructional design to provide an integrated approach for the literacy development of third-grade students, including English learners. 
The theoretical framework for this current study stems from a sociocultural perspective. The key concept to this sociocultural perspective of learning is that of psychological tools (Kozulin, 2003). According to the author, psychological tools are a learner's artifacts, such as text and graphic organizers, that when internalized assist the learner in mastering psychological functions, such as perception and memory. The current study used the Reciprocal Mapping (Fine, 2004) approach to incorporate the development of cognitive strategies and metacognitive skills to comprehend informational text. Lastly, the current study integrated this sociocultural perspective with instructional modifications that support the needs of English learners. These instructional modifications included building background knowledge of the cognitive structures related to text structures and developing vocabulary through the use English-Spanish cognates.

Recommendations for future research involve increasing the length of treatment time to increase opportunities for student to apply the skills acquired. Also, it is recommended to investigate how to adapt the current study's instructional design to better meet the needs of primary learners. 


\section{REFERENCES}

Afflerbach, P., Pearson, P. D., \& Paris, S. G. (2008). Clarifying differences between reading skills and reading strategies. The Reading Teacher, 61(5), 364-373.

Akhondi, M., Malayeri, F.A., \& Samad, A.A. (2011). How to teach expository text structure to facilitate reading comprehension. The Reading Teacher, 64(5), 368372.

Anderson, T. H., \& Armbruster, B. B. (1984). Content area textbooks. In R.C. Anderson, J. Osborn, \& R. J. Tierney (Eds.), Learning to read in American schools (pp. 193226). Hillsdale, NJ: Erlbaum

Ausubel, D.P. (1968). Educational psychology: A cognitive view. New York, NY: Holt, Rinehart \& Winston.

Bohaty, J.J., Hebert, M.A., Nelson, J.R., \& Brown, J.A. (2015). Methodological status and trends in expository text structure instruction efficacy research. Reading Horizons, 54(2), 34-65.

Cash, T. (2013). The Effect of Reciprocal Mapping on High-Risk Sixth-Grade Students' Social Studies Achievement (Doctoral dissertation). Retrieved from http://http://search.ebscohost.com/login.aspx?direct=true \&db=cat06026a\&AN=fi u.032452944\&site=eds-live (fiu.032452944)

Crosson, A.C., Lesaux, N.K., \& Martiniello, M. (2008). Factors that influence comprehension of connectives among language minority children from Spanishspeaking backgrounds. Applied Psycholinguistics, 29, 603-625.

Curriculum and Associates. (n.d.). The science behind the i-Ready's Adaptive Diagnostic. Retrieved March 25, 2017, from http://www.casamples.com/downloads/iReady_DiagnosticPositionPaper_090914.pdf

Darch, C. \& Eaves, R.C. (1986). Visual displays to increase comprehension of high school learning-disabled students. The Journal of Special Education, 20(3), 309318 .

Dewitz, P., Jones, J., \& Leahy, S. (2009). Comprehension strategy instruction in core reading programs. Reading Research Quarterly, 44(2), 102-126.

Duke, N.K. (2000). 3.6 minutes per day: The scarcity of informational texts in first grade. Reading Research Quarterly, 35(1), 202-224.

Duke, N.K., \& Bennett-Armistead, V.S. (2003). Reading \& writing informational text in the primary grades: Research-based practices. New York, NY: Scholastic Inc. 
Florida Department of Education. (n.d.). Retrieved September 19, 2018, from https://edstats.fldoe.org/SASWebReportStudio/openRVUrl.do?rsRID=SBIP\%3A \%2F\%2FMETASERVER\%2FARM\%2FPERA\%2FEIAS\%2FFSA+ELA\%2FWE B+REPORTS\%2FFSA+English+Language+Arts+\%28ELA\%29.srx\%28Report\% $\underline{29}$

Fine, J. C. (2004). Reciprocal Mapping: Scaffolding students' literacy to higher levels. In A. Rodgers \& E. M. Rodgers (Eds.), Scaffolding literacy instruction: Strategies for K-4 classrooms (pp. 88-104). Portsmouth, NH: Heinemann.

Fine, J.C. (2005). Reciprocal Mapping: Scaffolding students' expository writing. American Reading Forum Yearbook, Volume XXV. American Reading Forum.

Fishbein, M., \& Ajzen, I. (1975). Belief, attitude, intention, and behavior: An introduction to theory and research. Reading, MA: Addition-Wesley.

Florida Students Achieve. (n.d.). Elementary. Retrieved from https://www.floridastudentsachieve.org/elementary/

Goldenberg, C.N. (2011). Language and literacy development in bilingual settings. A. Y. Durgunoglu (Ed.). New York: Guilford Press.

Goldman, S.R., \& Rakestraw, J.A. (2000). Structural aspects of constructing meaning from text. M. L. Kamil, P. B. Mosenthal, P. D. Pearson, \& R. Barr (Eds.), Handbook of reading research, Vol. 3 (pp. 311-335). Mahwah, NJ: Lawrence Erlbaum.

Grabe, W. (2009). Reading in a second language: moving from theory to practice. New York: Cambridge University Press.

Graham, S., McKeown, D., Kiuhara, S., \& Harris, K. R. (2012). A meta-analysis of writing instruction for students in the elementary grades. Journal of Educational Psychology, 104, 879-896.

Griffin, C.C., Malone, L.D., \& Kameenui, E.J. (1998). Effects of graphic organizer instruction on fifth-grade students. The Journal of Educational Research, 89(2), 98-107.

Griffith, P. L., \& Ruan, J. (2005). What is metacognition and what should be its role in literacy instruction? In S. E. Israel, C. C. Block, K. L. Bauserman, \& K. Kinnucan-Welsch (Eds.), Metacognition in Literacy Learning: Theory, Assessment, Instruction, and Professional Development (pp. 3-18). Mahwah, NJ: L. Erlbaum Associates. 
Hall, K.M., Sabey, B. L., \& McClellan, M. (2005). Expository text comprehension: Helping primary-grade teachers use expository texts to full advantage. Reading Psychology, 26, 211-234.

Hebert, M., Bohaty, J.J., Nelson, J.R., \& Brown, J. (2016). The effects of text structure instruction on expository reading comprehension: A meta-analysis. Journal of Educational Psychology, 108(5), 609-629.

Hernandez, A.C., Montelongo, J.A., \& Herter, R.J. (2016). Using Spanish-English cognates in children's choices picture books to develop Latino English learners' linguistic knowledge. The Reading Teacher, 70(2), 233-239.

Keene, E. O. (2011). Comprehension Instruction Grows Up. In H. Daniels (Eds.), Comprehension Going Forward Where we are / what's next (9-33). Portsmouth, NH: Heinemann.

Kozulin, A. (2003). Psychological tools and mediated learning. In A. Kozulin, B. Gindis, V.A. Ageyev\& S.M. Miller (Eds.), Vygotsky's educational theory in cultural context (pp.15-38). UK: Cambridge University Press.

Lubliner, S., \& Hiebert, E.H. (2011). An analysis of English- Spanish cognates as a source of general academic language. Bilingual Research Journal, 34(1), 76-93.

Marcell, B. DeCleene, J. \& Juettner, M. (2010). Caution! Hard hat area! Comprehension under construction: Cementing a foundation of comprehension strategy usage that carries over to independent practice. The Reading Teacher, 63(8), 678-691.

McKenna, M.C., \& Kear, D.J. (1990). Measuring attitude toward reading: A new tool for teachers. The Reading Teacher, 43(8), 626-639.

McKenna, M., Kear, D., \& Ellsworth, R. (1995). Children's attitudes toward reading: A national survey. Reading Research Quarterly, 30(4), 934-956.

Meyer, B. J. F. (1975). The organization of prose and its effects on memory. Amsterdam: North Holland Publishing.

Meyer, B.J.F. (1985). Prose analysis: Purposes, procedures, and problems. In B.K. Britten \& J.B. Black (Eds.), Understanding expository text: A theoretical and practical handbook for analyzing explanatory text (pp. 11-64). Hillsdale, NJ: Erlbaum.

Meyer, B.J.F., Wijekumar, K. \& Lei, P. (2018). Comparative signaling generated for expository texts by 4th-8th graders: Variations by text structure strategy instruction, comprehension skill, and signal word. Reading and Writing, 1-32. doi:http://dx.doi.org.ezproxy.fiu.edu/10.1007/s11145-018-9871-4 
Meyer, B.J.F., Wijekumar, K.K., \& Lin, Y.C. (2011). Individualizing a web-based structure strategy intervention for fifth graders' comprehension of nonfiction. Journal of Educational Psychology, 103(1), 140-168.

Miami Dade County Public Schools. (n.d.). ESOL functional levels. Retrieved from http://bilingual.dadeschools.net/BEWL/pdf/ESOL_Functional_Levels.pdf

National Council of Teachers of English. (2008). English language learners: A policy research brief produced by the National Council of Teachers of English. Retrieved from

http://www.ncte.org/library/NCTEFiles/Resources/Positions/Chron0308PolicyBri ef.pdf

National Governors Association Center for Best Practices, Council of Chief State School Officers. (2010). Common Core State Standards. National Governors Association Center for Best Practices, Council of Chief State School Officers. Washington, D.C.

National Institute of Child Health and Human Development. (2000). Report of the National Reading Panel: Teaching children to read. An evidence-based assessment of the scientific research literature on reading and its implications for reading instruction (NIH Publication No.00-4769). Washington, DC: U.S. Government Printing Office.

Ogle, D., \& Correa-Kovtun, A. (2010). Supporting English-language learners and struggling readers in content literacy with the "partner reading and content, too" routine. The Reading Teacher, 63(7), 532-542.

Pang, Y. (2013). Graphic organizers and other visual strategies to improve young ELLs' reading comprehension. The NERA Journal, 48(2), 52-58.

Pearson, P. D. (2009). The roots of reading comprehension instruction. In S.E. Israel \& G.G. Duffy (Eds.), Handbook of research on reading comprehension (pp.3-31). New York, NY: Routledge.

Petscher, Y. (2010). A meta-analysis of the relationship between student attitudes towards reading and achievement in reading. Journal of Research in Reading, 33(4), 335-355.

Rumelhart, D. E. (1977). Understanding and summarizing brief stories. In D. LaBerge \& J. Samuels (Eds.), Basic processes in reading perception and comprehension. Hillsdale, NJ: Erlbaum. 
Snow, C.E., Science and Technology, P.I., \& States, U. (2002). Reading for understanding: Toward an R\&D program in reading comprehension. Santa Monica, CA: RAND Corporation.

Snow, C.E., Burns, S.M., \& Griffin, P. (Eds.). (1998). Preventing reading difficulties in young children. Washington, D.C.: National Academy Press.

Tompkins, G.E. (1998). Language arts: Content and teaching strategies. Upper Saddle River, NJ: Merrill.

U.S. Department of Education. Institute of Education Sciences, National Center for Education Statistics (2018).

Vygotsky, L.S. (1978). Mind in society: The development of higher psychological processes. Cambridge, MA: Harvard University Press.

Weisberg, R. (1990). Research into practice. Reading Today, 8(1), 31.

World-Class Instructional Design and Assessment. (2012). The English language learner can do booklet: Grades 3-5. Board of Regents of the University of Wisconsin System. Retrieved from https://www.wida.us/standards/CAN_DOs/.

Williams, J.P. (2005). Instruction in reading comprehension for primary-grade students: A focus on text structure. The Journal of Special Education, 39(1), 6-18.

Williams, J.P., Hall, K.M., Lauer, K.D., Stafford, B., DeSisto, L.A. \& Decani, J.S. (2005). Expository Text Comprehension in the Primary Grade Classroom. Journal of Educational Psychology, 97(4), 538-550.

Williams, J.P., Nubla-Kung, A.M., Pollini, S., Stafford, K.B., Garcia, A., \& Snyder, A.E. (2007). Teaching cause-effect text structure through social studies content to atrisk second graders. Journal of Learning Disabilities, 40, 111-120. 


\section{APPENDICES}

APPENDIX A

Parent Information Letter and Consent Form in English and Spanish

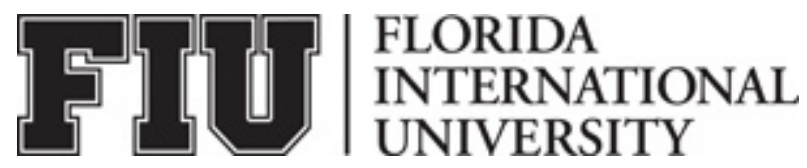

\section{PARENTAL CONSENT TO PARTICIPATE IN A RESEARCH STUDY}

\section{TITLE OF RESEARCH STUDY}

The Effect of Reciprocal Mapping on Third-Grade English Learners' Reading

Comprehension Achievement and Reading Attitudes

\section{DESCRIPTION AND PROCEDURES OF THE STUDY}

You are being asked to give your permission for your child to be in a research study. The goal of this study is to learn whether a reading approach will increase reading comprehension achievement and reading attitudes. You are being asked to take part in this study because your child is in third grade and could benefit from receiving instruction on comprehending science text. Please read this form and ask any questions you may have before you agree to participate in this study. If you decide to be part of this study you will allow your child to do the following things:

1. Take two reading tests. The first test is the i-Ready computer test that is already required by the school and will take about one hour to complete. The second test is the Elementary Reading Attitude Survey and will take about 20 minutes to complete and it is a paper test.

2. Learn and use reading strategies with science text. This will require 90 minutes per week for 10 weeks.

3. Take the two reading tests again. The first test is the i-Ready computer test that is already required by the school and will take about one hour to complete. The second test is the Elementary Reading Attitude Survey and will take about 20 minutes to complete and it is a paper test.

\section{DATA}

The following data will be collected on your child:

1. ESOL level

2. Reading score on the first and second administration of the i-Ready Diagnostic

3. Reading Attitude score on the first and second administration of the Elementary Reading Attitude Survey 


\section{NUMBER OF STUDY PARTICIPANTS}

If you agree to allow your child to participate in this study, he/she will be one of 130 students in this research study.

\section{DURATION OF THE STUDY}

Your child's participation will require 90 minutes per week for 10 weeks.

\section{RISKS AND/OR DISCOMFORTS}

There are no known risks associated with your child's participation in this study.

This study does not have anything - to the best of my knowledge - that may hurt you or make you feel bad. If you do feel bad in any way you can stop being part of the study at anytime. Nothing bad will happen to you if you stop being in the study.

\section{BENEFITS}

The following benefits may be associated with your child's participation in this study:

1. The possibility of increasing reading comprehension.

2. The possibility of improving reading attitude.

3. The possibility of learning science content.

\section{ALTERNATIVES}

There are no known alternatives available to your child other than not taking part in this study. However, any significant new findings developed during the course of the research which may relate to your child's willingness to continue participation will be provided to you.

\section{CONFIDENTIALITY}

The records of this study will be kept private and will be protected to the fullest extent provided by law. In any sort of report we might publish, we will not include any information that will make it possible to identify your child as a subject. Research records will be stored securely and only the researcher team will have access to the records. However, your child's records may be reviewed for audit purposes by authorized University or other agents who will be bound by the same provisions of confidentiality.

\section{COMPENSATION \& COSTS}

Your child will not receive a payment of for your participation. Your child will not be responsible for any costs to participate in this study. 


\section{RIGHT TO DECLINE OR WITHDRAW}

Your child's participation in this study is voluntary. Your child is free to participate in the study or withdraw his/her consent at any time during the study. Your child's withdrawal or lack of participation will not affect any benefits to which he/she is otherwise entitled. You are free to choose not to participate in the study without any penalty. If you decide to stop participating in the study the information gathered will be destroyed. The investigator reserves the right to remove your child from the study without your consent at such time that they feel it is in the best interest.

\section{RESEARCHER CONTACT INFORMATION}

If you have questions, ask us. If you have any questions about the purpose, procedures, or any other issues relating to this research study you may contact Olga Flamion at Florida International University, 305-226-7001, oflam001@ fiu.edu. You may also contact Dr. Joyce Fine at Florida International University, 3053486152, finej@fiu.edu.

\section{IRB CONTACT INFORMATION}

If you would like to talk with someone about your child's rights of being a subject in this research study or about ethical issues with this research study, you may contact the FIU Office of Research Integrity by phone at 305-348-2494 or by email at ori@fiu.edu.

\section{PARTICIPANT AGREEMENT}

I have read the procedures above. I voluntarily agree to allow my child to participate in the research study and I have received a copy of this description. I have had a chance to ask any questions I have about this study, and they have been answered for me. I understand that I will be given a copy of this form for my records.

Participant's Name:

Signature: Date:

\section{I give permission for my child to participate in the study.}

Parent's Name:

Signature:

Date:

\section{I do not give permission for my child to participate.}

Parent's Name:

Signature:

Date: 


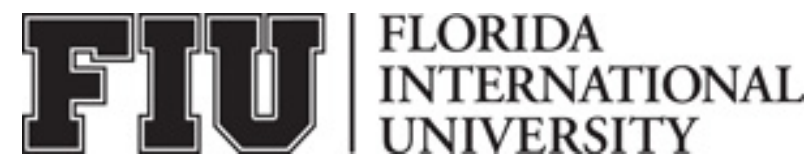

\section{CONSENTIMIENTO DE LOS PADRES PARA PARTICIPAR EN UN ESTUDIO DE INVESTIGACIÓN}

Título DEL ESTUDIO DE INVESTIGACION

El efecto de "Reciprocal Mapping" en la comprensión de la lectura y las actitudes de lectura de los aprendices de Inglés de tercer grado

\section{Descripción Y PROCEDIMIENTOS DEL ESTUDIO}

Se le pide permiso para que su hijo pueda estar en un estudio de investigación. El objetivo de este estudio es conocer si un enfoque de lectura aumentará la comprensión y las actitudes de lectura. Se le ha pedido que tome parte en este estudio porque su hijo está en el tercer grado, y podría beneficiarse de recibir instrucción en comprender texto de ciencia. Por favor lea este formulario y hacer cualquier pregunta que usted pueda tener antes de que usted acepte participar en este estudio. Si usted decide ser parte de este estudio le permitirá a su niño hacer lo siguiente:

1. Tomar dos pruebas de lectura. La primera prueba es la "i-Ready" prueba en la computatora que ya es requerido por la escuela y tardará alrededor de una hora en completarse. La segunda prueba es la encuesta de actitudes de lectura elementaria, "The Elementary Reading Attitude Survey", y tardará unos 20 minutos en completarse y es una encuesta escrita.

2. Aprender y utilizar estrategias de lectura con texto de ciencias. Esto requerirá 90 minutos por semana durante 10 semanas.

3. Tomar las dos pruebas de lectura de nuevo. La primera prueba es la "i-Ready" prueba en la computatora que ya es requerido por la escuela y tardará alrededor de una hora en completarse. La segunda prueba es la encuesta de actitudes de lectura elementaria, "The Elementary Reading Attitude Survey", y tardará unos 20 minutos en completarse y es una encuesta escrita.

\section{DATOS}

Los siguientes datos se recogerán en su hijo:

1. Nivel de ESOL

2. Puntuación de lectura en la primera y segunda administración del "i-Ready"

3. Puntuación de actitudes de lectura en la primera y segunda administración de la encuesta "The Elementary Reading Attitude Survey"

\section{NÚMERO DE PARTICIPANTES EN EL ESTUDIO}

Si usted está de acuerdo en permitir que su hijo participe en este estudio, él/ella será uno de 130 estudiantes en este estudio de investigación. 


\section{LA DURACIÓN DEL ESTUDIO}

La participación del niño requerirá 90 minutos por semana durante 10 semanas.

\section{LOS RIESGOS Y/O MALESTARES}

No existen riesgos conocidos asociados con la participación del niño en este estudio. Este estudio no tiene nada - de acuerdo a mi conocimiento - que pueda lastimar o hacer que se sienta mal. Si se siente mal puede dejar de ser parte del estudio en cualquier momento. Nada malo le va a pasar si deja de estar en el estudio.

\section{BENEFICIOS}

Los siguientes beneficios pueden estar asociados con la participación del niño en este estudio:

1. La posibilidad de aumentar la comprensión de la lectura.

2. La posibilidad de mejorar la actitud de lectura.

3. La posibilidad de aprender el contenido de ciencia.

\section{ALTERNATIVAS}

No tenemos alternativas disponibles para su hijo distinto de no tomar parte en este estudio. Sin embargo, información acerca de su niño seguir participando en el estudio será transmitido a usted.

\section{CONFIDENCIALIDAD}

Los registros de este estudio serán confidenciales y estan protegidos por la ley. Cualquier tipo de reporte que podamos publicar, no incluirá información que permita identificar a su hijo como un sujeto. Registros de la investigación se almacenerá de forma segura y sólo el equipo de investigadores tendrán acceso a los registros. Sin embargo, los registros del niño pueden ser revisado por razones de auditoría por la Universidad u otros agentes que estarán sometidos a las mismas disposiciones de confidencialidad.

\section{COMPENSACIÓN Y COSTOS}

Su hijo no recibirá pago por su participación. Su hijo no será responsable por ningún costo para participar en este estudio.

\section{DERECHO A DENEGAR O RETIRAR}

La participación del niño en este estudio es voluntaria. El niño es libre de participar en el estudio o retirar su consentimiento en cualquier momento durante el estudio. La retirada del niño o la falta de participación no afectará a los beneficios a que tiene derecho. Usted es libre de elegir no participar en el estudio, sin ningún tipo de penalización. Si usted decide dejar de participar en el estudio la información recopilada será destruido. El investigador se reserva el derecho a retirar a su hijo del estudio sin su consentimiento en el momento en que piense que es en el mejor interés.

\section{INFORMACIÓN DE CONTACTO DEL INVESTIGADOR}

Si usted tiene preguntas, por favor déjanos saber. Si usted tiene preguntas sobre el propósito, procedimientos o cualquier otras cuestiones relacionadas con este estudio 
puede ponerse en contacto con Olga Flamion en Florida International University, 305226-7001, oflam001@ fiu.edu. También puede ponerse en contacto con Dr. Joyce Fine en Florida International University, 3053486152, finej@ fiu.edu.

\section{IRB INFORMACION DE CONTACTO}

Si desea hablar con alguien acerca de los derechos de su hijo/a para participar en este estudio de investigación o sobre cuestiones éticas con este estudio de investigación, puede ponerse en contacto con FIU Office of Research Integrity por teléfono al 305-3482494 o por correo electrónico al ori@ fiu.edu.

\section{ACUERDO DEL PARTICIPANTE}

He leído los procedimientos anteriores. Acepto voluntariamente para permitir a mi hijo/a a participar en el estudio y he recibido una copia de esta descripción. He tenido la oportunidad de preguntar cualquier duda que tengo acerca de este estudio, y he recibido las respuestas necesarias. Entiendo que recibiré una copia de este formulario para mis registros.

Nombre del participante: La firma:

Fecha:

\section{Doy permiso para que mi hijo/a participe en el estudio.}

Nombre de Padre:

La Firma:

Fecha:

Yo no doy permiso para que mi hijo/a participe en el estudio.

Nombre de Padre:

La Firma:

Fecha:

Nombre del investigador: La Firma:

Fecha: 


\section{APPENDIX B}

Text Structure Materials

Text Structures Materials - Treatment Group

\begin{tabular}{|c|c|c|}
\hline Text Structure & Science Focus & Materials \\
\hline Description & $\begin{array}{l}\text { *Forms of energy } \\
\text { *Sound energy }\end{array}$ & $\begin{array}{l}\text { *Week } 1 \text { PowerPoint } \\
* \text { Week } 1 \text { Reciprocal Map } \\
\text { *Forms of Energy Text } \\
\text { Adapted from AIMS }\end{array}$ \\
\hline Sequence & *Light energy & $\begin{array}{l}\text { *Week } 2 \text { PowerPoint } \\
\text { *Week } 2 \text { Reciprocal Map } \\
\text { *Light Bounces! Text } \\
\text { Adapted from readworks.org }\end{array}$ \\
\hline Cause and Effect & *Heat energy & $\begin{array}{l}\text { *Week } 3 \text { PowerPoint } \\
\text { *Week } 3 \text { Reciprocal Map } \\
\text { *Heat Energy Text } \\
\text { Adapted from readworks.org }\end{array}$ \\
\hline $\begin{array}{l}\text { Compare and } \\
\text { Contrast }\end{array}$ & *Light waves & $\begin{array}{l}\text { *Week } 4 \text { PowerPoint } \\
\text { *Week } 4 \text { Reciprocal Map } \\
\text { *What is Light? Text } \\
\text { Adapted from readworks.org }\end{array}$ \\
\hline Problem Solution & *Renewable energy & $\begin{array}{l}\text { *Week } 5 \text { PowerPoint } \\
* \text { Week } 5 \text { Reciprocal Map } \\
* \text { Energy for Life Text } \\
\text { Adapted from readworks.org }\end{array}$ \\
\hline All Structures & *Energy & $\begin{array}{l}\text { *Exploring Text Structure: Energy } \\
\text { Retrieved from teacherspayteachers.com }\end{array}$ \\
\hline All Structures & *Energy & $\begin{array}{l}\text { *Exploring Text Structure: Energy } \\
\text { Retrieved from teacherspayteachers.com }\end{array}$ \\
\hline
\end{tabular}


Text Structures Materials - Control Group

\begin{tabular}{|c|c|c|}
\hline Text Structure & Science Focus & Materials \\
\hline Description & $\begin{array}{l}\text { *Forms of energy } \\
\text { *Sound energy }\end{array}$ & $\begin{array}{l}\text { *Forms of Energy Text } \\
\text { Adapted from AIMS } \\
\text { *Sounds Text } \\
\text { Adapted from Bow Tie Guy }\end{array}$ \\
\hline Sequence & *Light energy & $\begin{array}{l}* \text { Light Bounces! Text } \\
\text { Adapted from readworks.org } \\
\text { *Playing with Light Text } \\
\text { Adapted from readworks.org }\end{array}$ \\
\hline Cause and Effect & *Heat energy & $\begin{array}{l}* \text { Heat Energy Text } \\
\text { Adapted from readworks.org } \\
{ }^{*} \text { The Importance of Heat Text } \\
\text { Adapted from readworks.org }\end{array}$ \\
\hline $\begin{array}{l}\text { Compare and } \\
\text { Contrast }\end{array}$ & *Light waves & $\begin{array}{l}\text { *What is Light? Text } \\
\text { Adapted from readworks.org } \\
\text { *Electricity \& Energy - The Light Bulb } \\
\text { Adapted from readworks.org }\end{array}$ \\
\hline Problem Solution & *Renewable energy & $\begin{array}{l}\text { *Energy for Life Text } \\
\text { Adapted from readworks.org } \\
\text { * Power from the Sun and Wind Learn } \\
\text { about Earth-friendly energy } \\
\text { Adapted from readworks.org }\end{array}$ \\
\hline All Structures & *Energy & $\begin{array}{l}\text { *Exploring Text Structure: Energy } \\
\text { Retrieved from teacherspayteachers.com }\end{array}$ \\
\hline All Structures & *Energy & $\begin{array}{l}\text { *Exploring Text Structure: Energy } \\
\text { Retrieved from teacherspayteachers.com }\end{array}$ \\
\hline
\end{tabular}




\section{APPENDIX C}

PowerPoint Presentations for Reciprocal Mapping Lessons

\section{Week 1 PowerPoint}

We are going to be learning about a strategy that can help you better comprehend nonfiction science text.
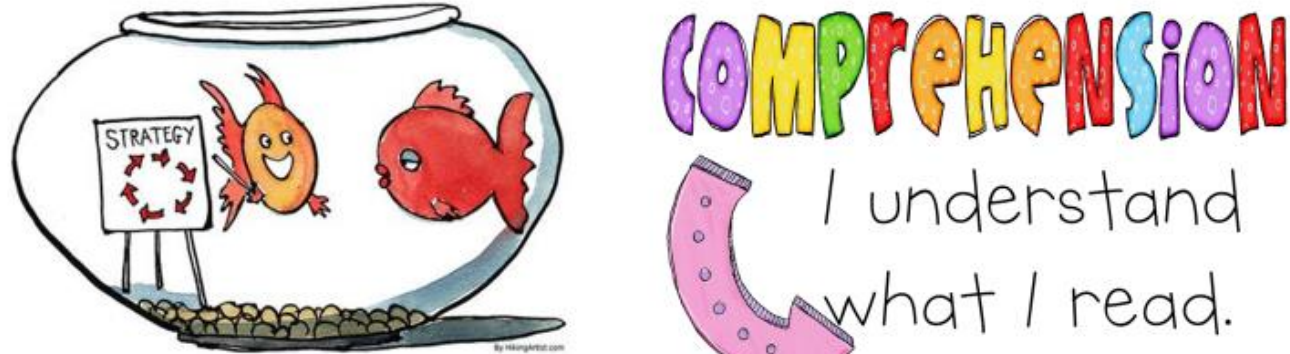

A strategy is something that

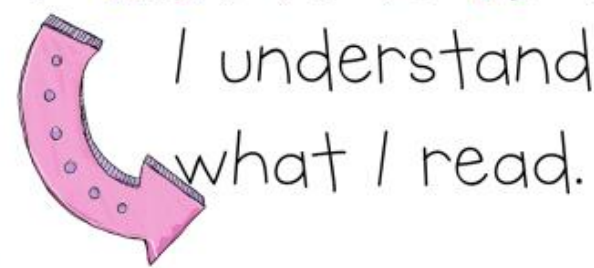
helps you achieve a skill.

\section{Nonfiction Science Text is text that provides information about science topics.}

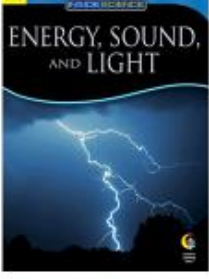

1. From Caterpillar to BUTTERFLY

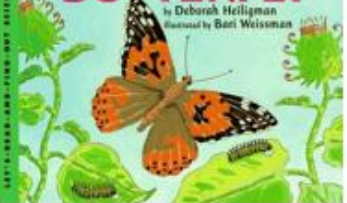

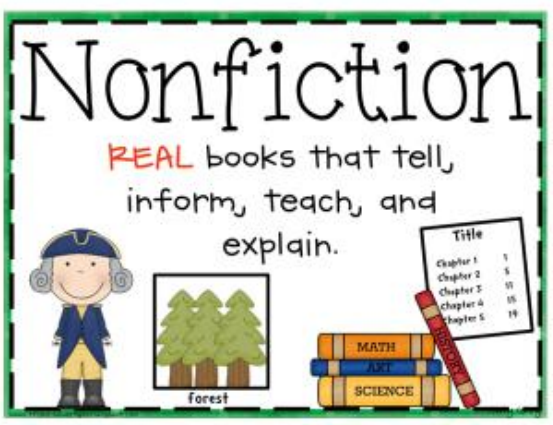

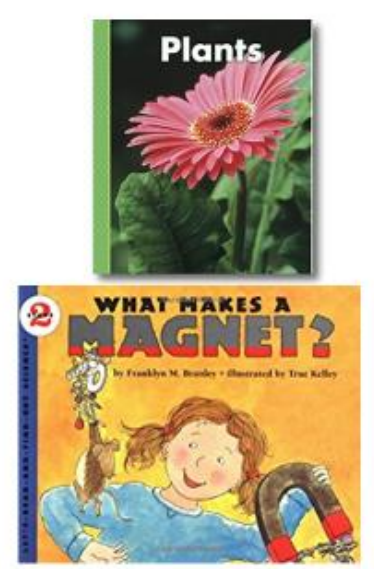


The strategy that we will be learning about is understanding text structure to better comprehend.

Text Structure is how the author organizes the text to help the reader better understand the text.

Five Most Common Text Structures

\begin{tabular}{|c|c|c|c|}
\hline Structure & Defrition & Visual & Clues \\
\hline Description & $\begin{array}{l}\text { the author provides } \\
\text { several detals of } \\
\text { sonething to give the } \\
\text { reoder a mentdl picture }\end{array}$ & & $\begin{array}{l}\text { mony adectives, } \\
\text { charocteristics, } \\
\text { or examples }\end{array}$ \\
\hline $\begin{array}{l}\text { Compare \& } \\
\text { Contrast }\end{array}$ & $\begin{array}{l}\text { the asthor dscasses } \\
\text { smiantes and dfferences } \\
\text { between people, thros. } \\
\text { concepts, or ideas }\end{array}$ & & $\begin{array}{l}\text { lkenesses and } \\
\text { dfferences are } \\
\text { dscoussed also, } \\
\text { both n contrast. } \\
\text { etc }\end{array}$ \\
\hline $\begin{array}{l}\text { Order \& } \\
\text { Sequence }\end{array}$ & $\begin{array}{l}\text { the outhor provides } \\
\text { reoders wth } \\
\text { cironologcel events or a } \\
\text { ist of steps in a } \\
\text { procedire }\end{array}$ & & $\begin{array}{l}\text { events } n \text { order } \\
\text { of occurrence. } \\
\text { nstructors gven } \\
\text { step-by-step, } \\
\text { order words } \\
\text { frst, next, etc }\end{array}$ \\
\hline $\begin{array}{c}\text { Problem \& } \\
\text { Solution }\end{array}$ & $\begin{array}{l}\text { the outhor gives } \\
\text { nformation about a } \\
\text { probiem and explans one } \\
\text { or more solutions }\end{array}$ & & $\begin{array}{l}\text { a problem is } \\
\text { solved or needs } \\
\text { solving problem } \\
\text { soltion solve }\end{array}$ \\
\hline $\begin{array}{l}\text { Couse \& } \\
\text { Effect }\end{array}$ & $\begin{array}{l}\text { the author describes an } \\
\text { event or several events } \\
\text { (cause) and the events } \\
\text { that follow (effect) }\end{array}$ & & $\begin{array}{l}\text { couse, becouse, } \\
\text { effect, as a } \\
\text { resit of, due to. } \\
\text { reason }\end{array}$ \\
\hline
\end{tabular}

\section{Description}

This week we will be focusing on the description text structure.

A description provides several details about a topic and can be organized in a web.

You provide descriptions through out the day. For example, you may have described an object like a car.

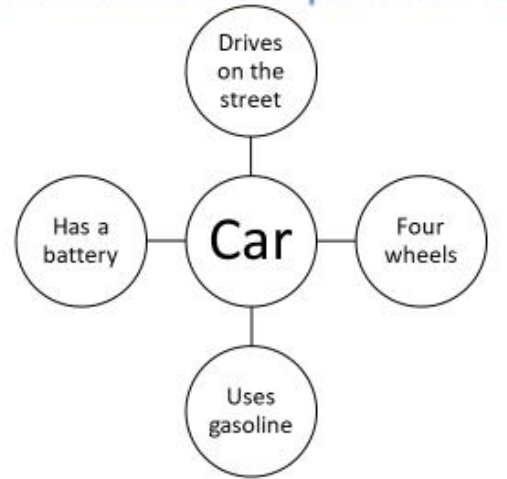




\section{Description}

A description uses signal words such as:

An example of

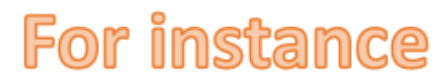

咆 is

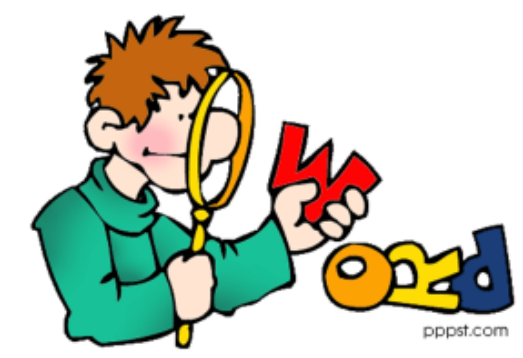

Such as

\section{Your Turn to Plan a Description}

Describe your favorite mode of transportation. Some examples could be a bicycle, car, bus, train, hot air balloon, or airplane.

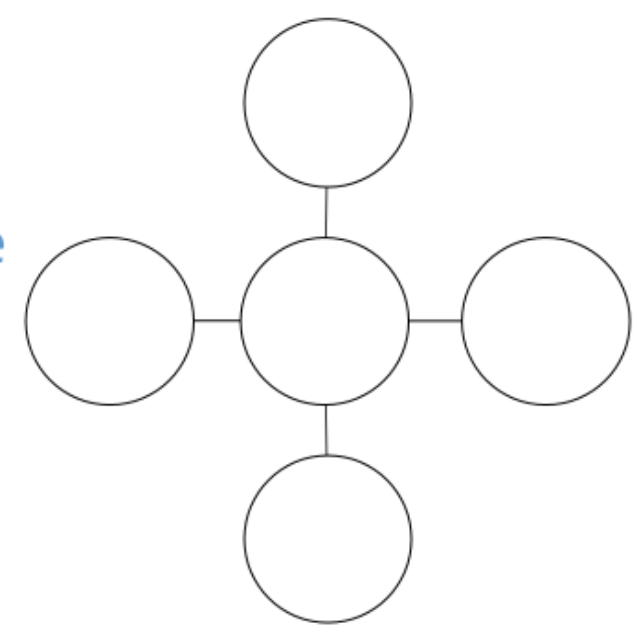




\section{Forms of Energy}

Let's read a nonfiction science text.

Here are important vocabulary words that we will encounter in the article with their translations. The words with an asterisk $\left({ }^{*}\right)$ are Spanish cognates, meaning the English and Spanish word are similar in spelling.

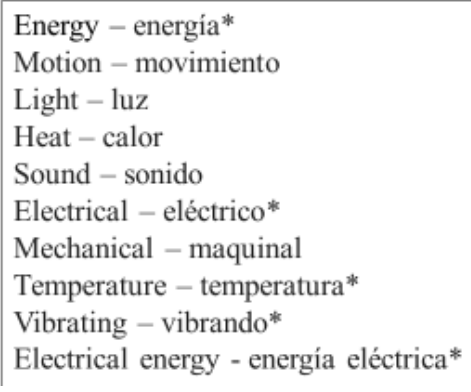

\section{Forms of Energy}

Now that we have read "Forms of Energy" let's find some of the key words for a description in the text.

\section{Light energy}

Light is a form of energy that allows us to see objects. Our main source of light is the sun. Other examples of sources of light energy are fires and electric lights.

Can you find other examples of where the author uses key words?

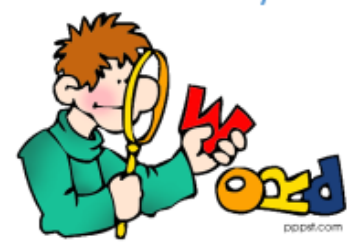

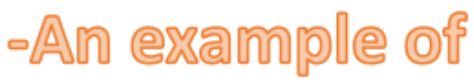
- ป็น กิร -For i̊nstance -Such as 


\section{Forms of Energy}

Now that we have read "Forms of Energy" let's use the web to organize the ideas in the text.

What is the topic of the text? What is the author describing?

What details do the author provide about the topic?

The information in the web helps me understand that the author uses a description text structure to describe the different forms of energy.

\section{Forms of Energy}

This is what your web should look like:

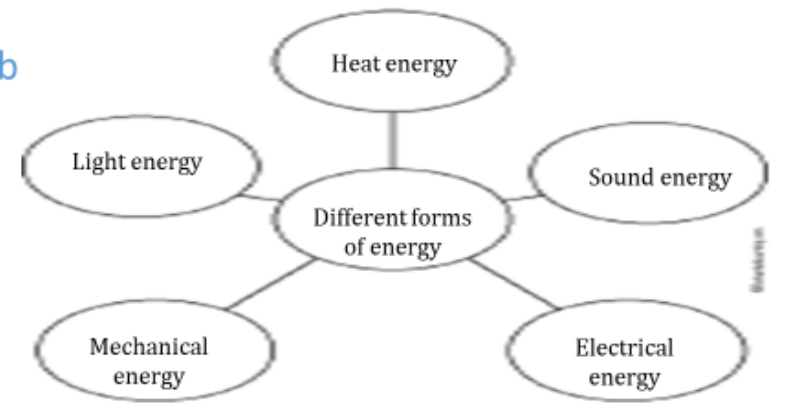

Text Structure: (Description, Sequence, Problem/Solution, Cause \& Effect, Compare/ Contrast)

Main Idea/Key Concept:

Different forms of energy 


\section{Forms of Energy}

Now we are going to write a summary of what we read by using evidence from the text and web.

Start with the main topic.

Provide a brief explanation for each of the details.

\section{Forms of Energy}

Here is an example of a summary:

Write using evidence:

There are different forms of energy. Light energy is a form of energy that allows us to see objects. Things that give off heat are sources of heat energy. Sound energy is the energy of vibrating objects. Electrical energy is produced by electric charges. Mechanical energy is the energy of moving things or things than can move because of their position. 


\section{Week 2 PowerPoint}

We are going to continue learning about a strategy that can help you better comprehend nonfiction science text. Let's review what a strategy is and what comprehension means.
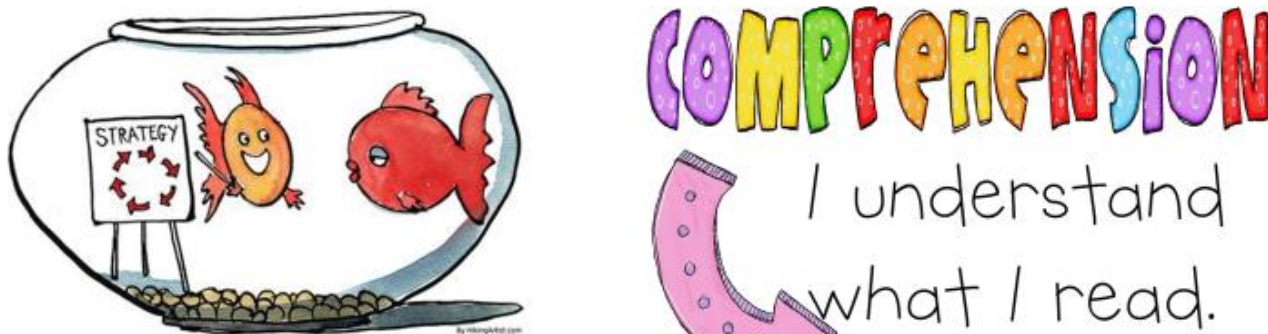

A strategy is something that

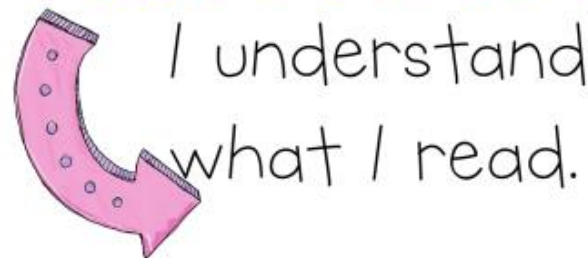
helps you achieve a skill.

Remember, Nonfiction Science Text is text that provides information about science topics.

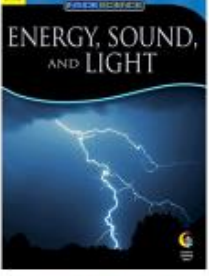

4 BUTTERFLY

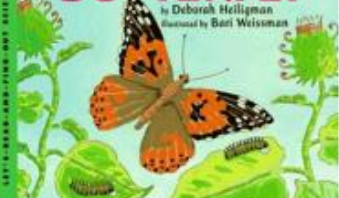

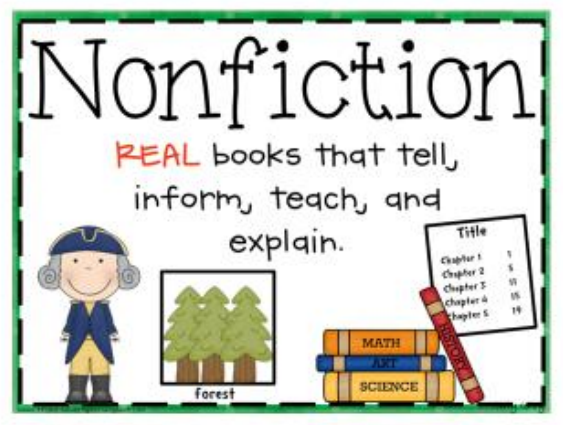

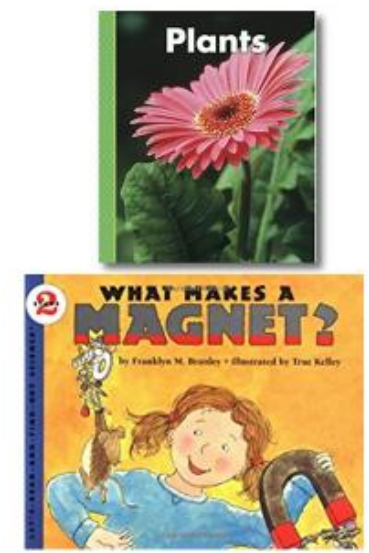


Remember that the strategy we are learning about is understanding text structure to better comprehend.

Remember, Text Structure is how the author organizes the text to help the reader better understand the text.

We focused on Description last week.

\begin{tabular}{|c|c|c|c|}
\hline Structure & Definition & Visual & Clues \\
\hline Description & $\begin{array}{l}\text { the outhor provides } \\
\text { several detais of } \\
\text { something to gve the } \\
\text { reoder a mental picture }\end{array}$ & & $\begin{array}{c}\text { mony agectives } \\
\text { charocteristics, } \\
\text { or examples }\end{array}$ \\
\hline $\begin{array}{l}\text { Compare \& } \\
\text { Contrast }\end{array}$ & $\begin{array}{l}\text { the author dscusses } \\
\text { smicntes and dfferences } \\
\text { between people, thrys. } \\
\text { concepts, or ideas }\end{array}$ & & $\begin{array}{l}\text { Ikenesses and } \\
\text { dfferences are } \\
\text { dscuussed diso, } \\
\text { both in contrast } \\
\text { etc }\end{array}$ \\
\hline $\begin{array}{l}\text { Order \& } \\
\text { Sequence }\end{array}$ & $\begin{array}{l}\text { the outhor provides } \\
\text { reoders with } \\
\text { crronologcel events or a } \\
\text { ist of steps in a } \\
\text { procedure }\end{array}$ & & $\begin{array}{l}\text { events norder } \\
\text { of occurrence. } \\
\text { nstructors gver } \\
\text { step-by-step. } \\
\text { order words } \\
\text { frst, next, etc }\end{array}$ \\
\hline $\begin{array}{l}\text { Problem \& } \\
\text { Solution }\end{array}$ & $\begin{array}{l}\text { the outhor gives } \\
\text { nformation about a } \\
\text { problem and explans one } \\
\text { or more solutions }\end{array}$ & & $\begin{array}{l}\text { a problem is } \\
\text { solved or needs } \\
\text { solving problem } \\
\text { solution solve }\end{array}$ \\
\hline $\begin{array}{l}\text { Couse \& } \\
\text { Effect }\end{array}$ & $\begin{array}{l}\text { the author descrbes an } \\
\text { event or severd events } \\
\text { (couse) and the events } \\
\text { that follow (effect) }\end{array}$ & & $\begin{array}{l}\text { couse, becouse, } \\
\text { effect, as a } \\
\text { result of, due to } \\
\text { reason }\end{array}$ \\
\hline
\end{tabular}

\section{Sequence}

This week we will be focusing on the sequence text structure.

A sequence describes events in order or explains the steps one must follow to do something or make something and can be organized in a flow chart.

You provide sequential information through out the day. For example, you may have explained the steps of how to play your favorite game.
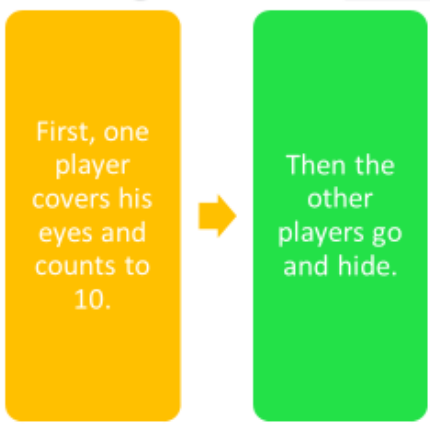

counted

goes and

looks for the

other

players. 


\section{Sequence}

A sequence uses signal words such as:

Fற̊?కโ

รำลปty

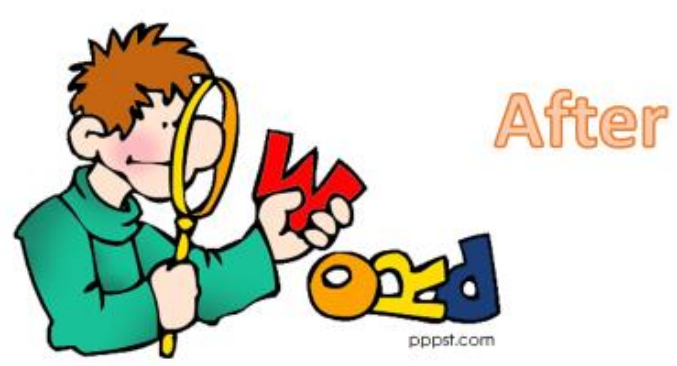

Last

\section{Then}

\section{Your Turn to Plan a Sequence}

Explain the steps of your favorite game.
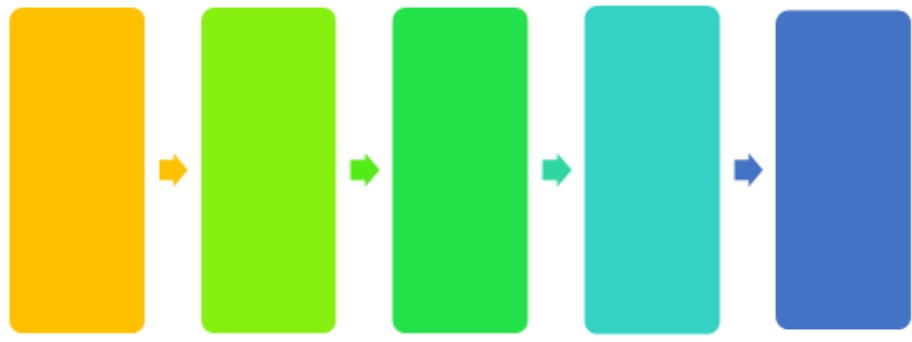


\section{Light Bounces!}

Let's read a nonfiction science text.

Here are important vocabulary words that we will encounter in the article with their translations. The words with an asterisk (*) are Spanish cognates, meaning the English and Spanish word are similar in spelling.

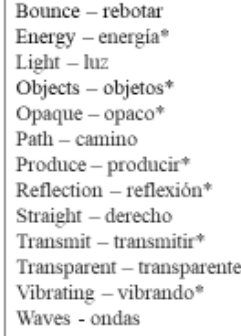

\section{Light Bounces!}

Now that we have read "Light Bounces!" let's find some of the key words for a sequence in the text.

\section{How Does Light Travel?}

Some objects produce their own light, but most do not. The walls in the room you are in do not give off their own light. How do we see things? First, light from any source travels in a straight path in waves. Since light does not travel through all objects, the light then bounces off an object. Last, the light goes into our eyes and we are able to see that object.

\section{Can you find other examples of where}

the author uses key words?

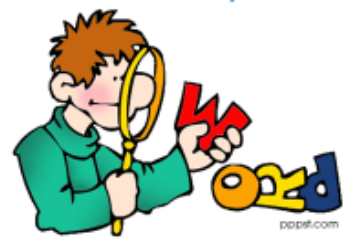

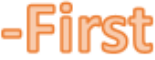

- Before

-Then

- Last

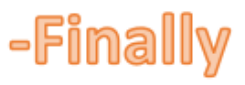

- As 


\section{Light Bounces!}

Now that we have read "Light Bounces!" let's use the flow chart to organize the ideas in the text, specially the section where the author explains how light travels towards opaque objects.

What is the topic of the text? What is the author explaining?

What details do the author provide about these steps?

\section{Light Bounces!}

This is what your flow chart should look like:

The information in the flow chart helps me understand that the author uses a sequence text structure to explain how light travels.

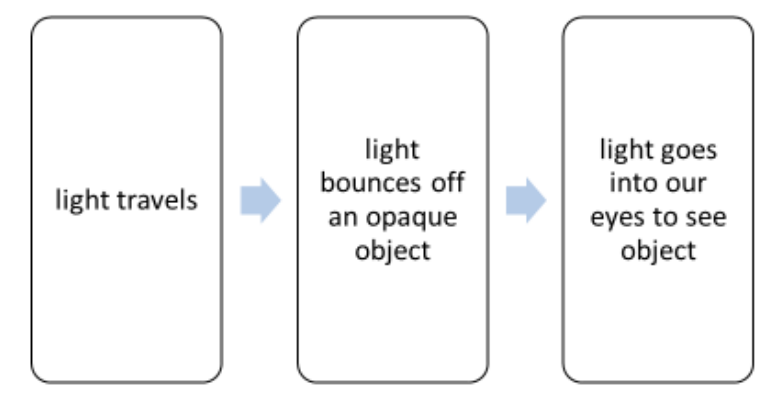

Text Structure: (Description, Sequence,

Problem/Solution, Cause \& Effect,

Compare/ Contrast)

Main Idea/Key Concept:

How light travels 


\section{Light Bounces!}

Now we are going to write a summary of what we read by using evidence from the text and flow chart.

Start with the main topic.

Provide a brief explanation for each of the steps.

\section{Light Bounces!}

Here is an example of a summary:

Write using evidence:

How does light help us see objects? First, light from any source travels in a straight path in waves. Then the light bounces, or reflects, off an opaque object. Last, the light goes into our eyes and we are able to see that object. 


\section{Week 3 PowerPoint}

We are going to continue learning about a strategy that can help you better comprehend nonfiction

science text. Let's review what a strategy is and what comprehension means.

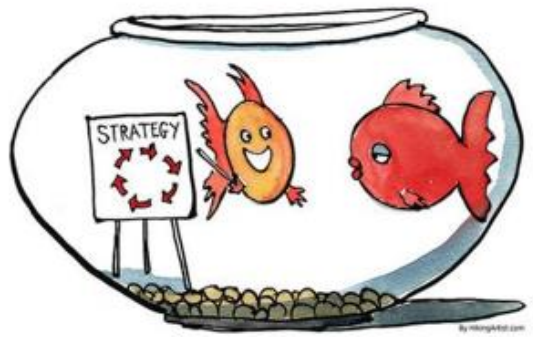

A strategy is something that

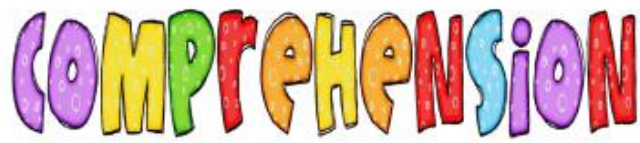
helps you achieve a skill.

Remember, Nonfiction Science Text is text that provides information about science topics.

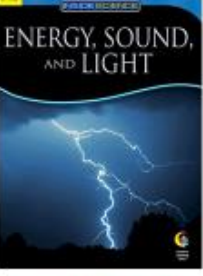

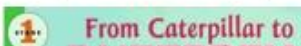
BUTTERFLY ins
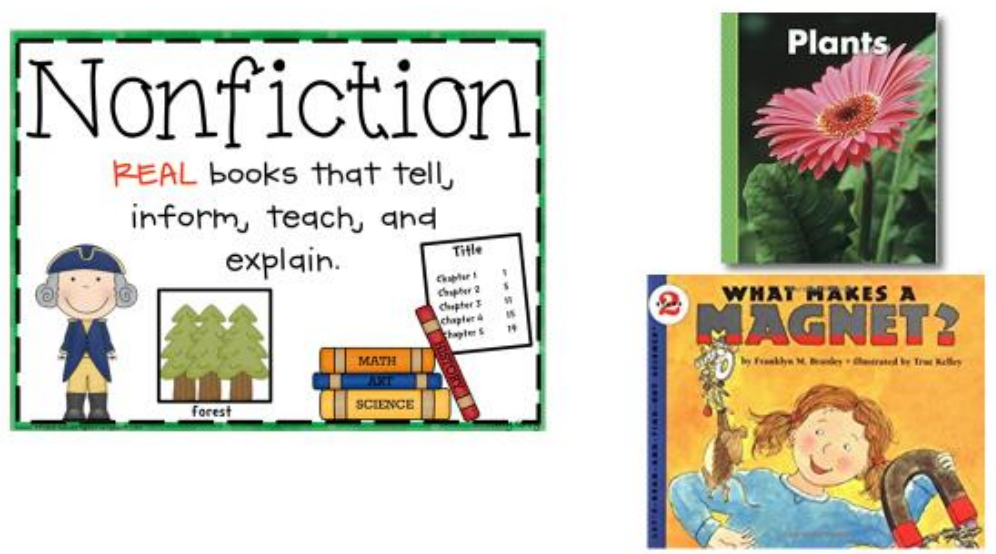
Remember that the strategy we are learning about is understanding text structure to better comprehend.

Remember, Text Structure is how the author organizes the text to help the reader better understand the text.

We have focused on Description and Sequence.

\begin{tabular}{|c|c|c|c|}
\hline Structure & Definition & Visual & Clues \\
\hline Description & $\begin{array}{l}\text { the outhor provides } \\
\text { several detals of } \\
\text { somethng to give the } \\
\text { reoder a mental picture }\end{array}$ & & $\begin{array}{l}\text { many adectives } \\
\text { charocteristics, } \\
\text { or exomples }\end{array}$ \\
\hline $\begin{array}{c}\text { Compare \& } \\
\text { Contrast }\end{array}$ & $\begin{array}{l}\text { the athor dscusses } \\
\text { simiontes and dfferences } \\
\text { between people, thrigs, } \\
\text { concepts, or ideas }\end{array}$ & & $\begin{array}{l}\text { Ikenesses and } \\
\text { dfferences are } \\
\text { dscussed dso, } \\
\text { both n contrast } \\
\text { etc }\end{array}$ \\
\hline $\begin{array}{l}\text { Order \& } \\
\text { Sequence }\end{array}$ & $\begin{array}{l}\text { the outhor provides } \\
\text { reoders wth } \\
\text { ctronobogcl events or a } \\
\text { ist of steps na } \\
\text { procedire }\end{array}$ & & $\begin{array}{l}\text { events n order } \\
\text { of occurrence. } \\
\text { rstructors gver } \\
\text { step-by-step, } \\
\text { order words } \\
\text { frst, next, etc }\end{array}$ \\
\hline $\begin{array}{l}\text { Problem \& } \\
\text { Solution }\end{array}$ & $\begin{array}{l}\text { the outhor gives } \\
\text { nformation about a } \\
\text { problem and explans one } \\
\text { or more solutions }\end{array}$ & & $\begin{array}{l}\text { a problem is } \\
\text { solved or needs } \\
\text { solving prodiem, } \\
\text { solition solve }\end{array}$ \\
\hline $\begin{array}{l}\text { Couse \& } \\
\text { Effect }\end{array}$ & $\begin{array}{l}\text { the author descrbes an } \\
\text { event or severd events } \\
\text { (couse) and the events } \\
\text { that follow (effect) }\end{array}$ & & $\begin{array}{l}\text { couse, becouse. } \\
\text { effect, as a } \\
\text { resilt of, due to } \\
\text { reason }\end{array}$ \\
\hline
\end{tabular}

\section{Cause and Effect}

This week we will be focusing on the cause and effect text structure.

A cause and effect relationship describes the reasons why something happened and can be organized in a diagram.

You provide cause and effect relationships through out the day. For example, you earned an ' $A$ ' on a test because you paid attention in class and

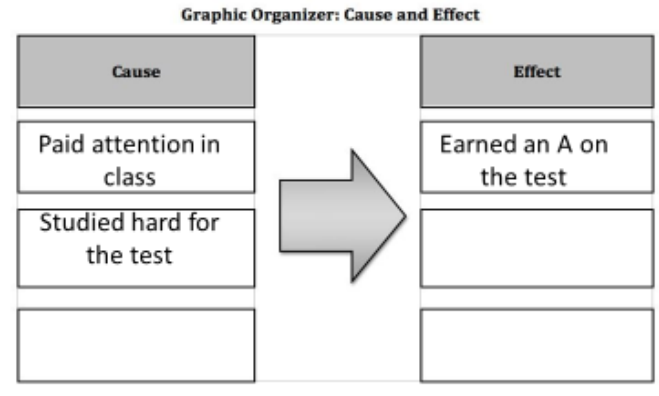
studied hard for the test. 


\section{Cause and Effect}

Cause and Effect relationships use signal words such as:

Because of

As a resulte

Due ţo

\section{consequently}

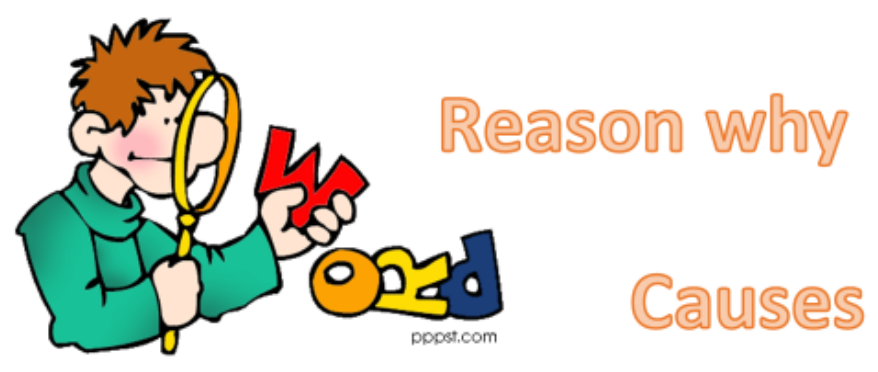

Your Turn to Plan a Cause and Effect Relationship Explain the possible results of the electricity shutting off in your house.

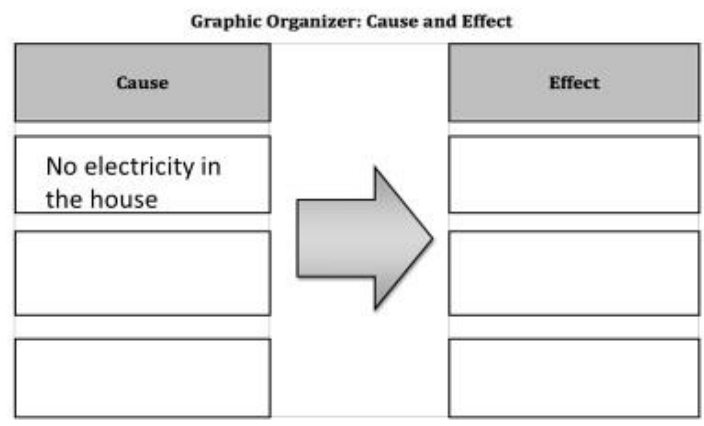




\section{Heat Energy}

Let's read a nonfiction science text.

Here are important vocabulary words that we will encounter in the article with their translations. The words with an asterisk $\left({ }^{*}\right)$ are Spanish cognates, meaning the English and Spanish word are similar in spelling.

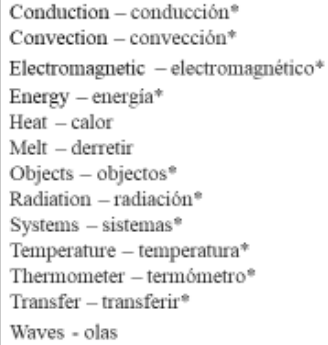

\section{Heat Energy}

Now that we have read "Heat Energy" let's find some of the key words for a cause and effect relationship in the text.

Heat is being transferred from the fire in the fireplace to the air in the room. There are a few changes in the room because the room is becoming warmer. The ice cream sundaes are melting in their bowls. The ice cubes in the glasses of water are melting. Due to the room warming, the children no longer need their thick blankets to sleep. The most obvious reason that heat is moving from the fire to the room is the thermometer showing a higher temperature than before the fire started.

Can you find other examples of where the author uses key words?

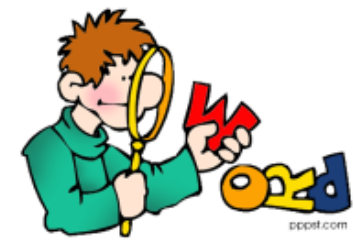

- Theref?re

-Due \{ூం

- Reason why

-Cேuுses

- Because of

- As a resunlf

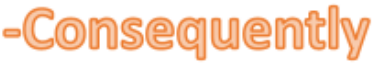




\section{Heat Energy}

Now that we have read "Heat Energy" let's use the diagram to organize the ideas in the text, specially the section where the author explains the effects of the room warming because of the fire from the fireplace.

What is the topic of the text? What is the author explaining?

What details does the author provide about the effects of the heat transferring from the fireplace to the room?

\section{Heat Energy}

Graphic Organizer: Cause and Effect

This is what your diagram should look like:

The information in the diagram helps me understand that the author uses a cause and effect text structure to explain the effects of heat energy.

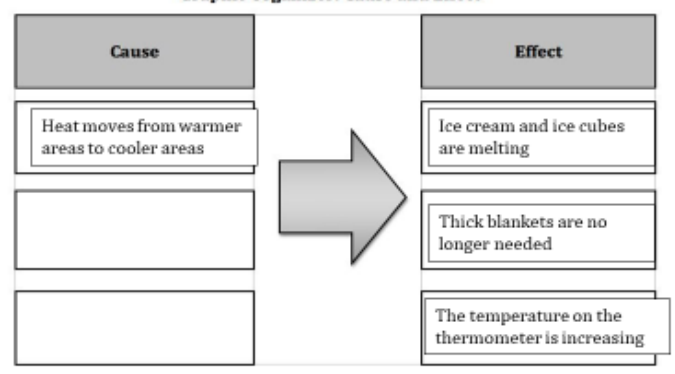

Text Structure: (Description, Sequence, Problem/Solution, Cause \& Effect, Compare/ Contrast)

Main Idea/Key Concept:

\section{Heat Energy}




\section{Heat Energy}

Now we are going to write a summary of what we read by using evidence from the text and diagram.

Start with the main topic.

Provide a brief explanation of the effects of the room warming.

\section{Heat Energy}

Here is an example of a summary:

Write using evidence:

Heat energy is energy being moved between two objects or systems that have different temperatures. Heat moves from warmer areas to cooler areas. The heat from the fireplace is warming the room. This heat is causing the ice cream and ice cubes to melt, blankets to not be needed, and the temperature on the thermometer to increase. 


\section{Week 4 PowerPoint}

We are going to continue learning about a strategy that can help you better comprehend nonfiction science text. Let's review what a strategy is and what comprehension means.

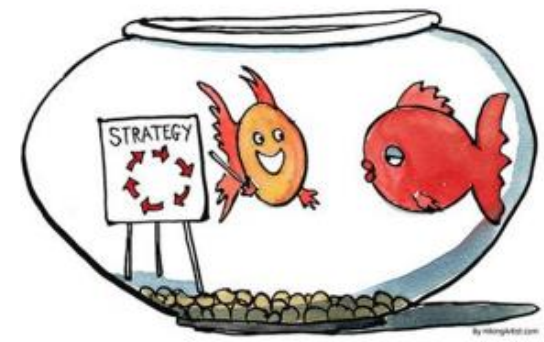

A strategy is something that

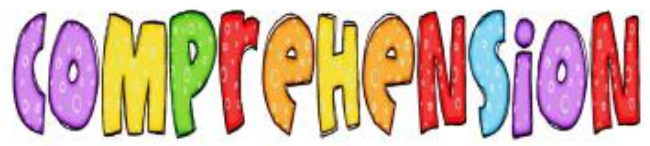
helps you achieve a skill.

Remember, Nonfiction Science Text is text that provides information about science topics.

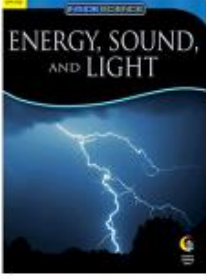

4. From Caterpillar to BUTTERFLY

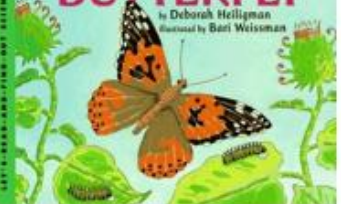

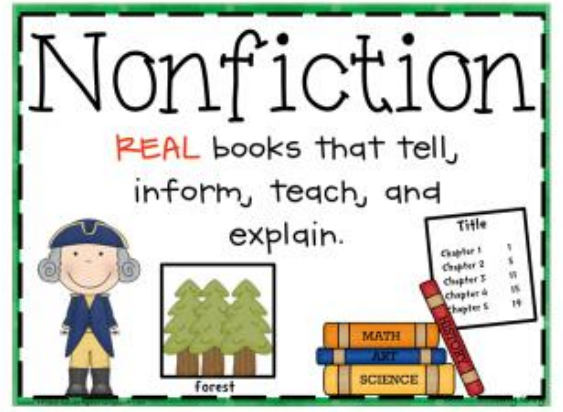

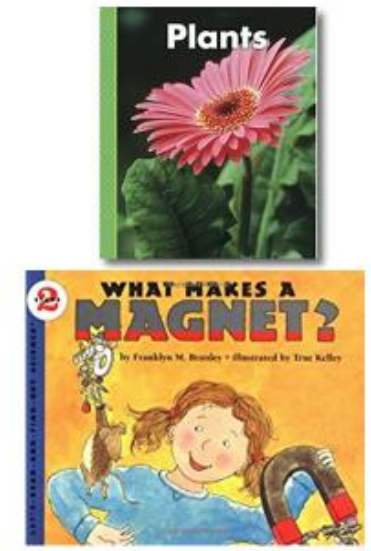


Remember that the strategy we are learning about is understanding text structure to better comprehend.

Remember, Text Structure is how the author organizes the text to help the reader better understand the text.

We have focused on Description, Sequence, and Cause \& Effect.

\begin{tabular}{|c|c|c|c|}
\hline Structure & Definition & Visual & Clues \\
\hline ption & $\begin{array}{l}\text { the outhor provides } \\
\text { several detals of } \\
\text { somethng to give the } \\
\text { reoder a mental picture }\end{array}$ & & $\begin{array}{l}\text { many adectives } \\
\text { charocteristics, } \\
\text { or examples }\end{array}$ \\
\hline $\begin{array}{c}\text { Compare \& } \\
\text { Contrast }\end{array}$ & $\begin{array}{l}\text { the authar dscusses } \\
\text { simiantes and dfferences } \\
\text { between people, thrgs. } \\
\text { concepts, or ideas }\end{array}$ & & $\begin{array}{l}\text { Ikenesses and } \\
\text { dfferences are } \\
\text { dscuussed also, } \\
\text { both n contrast } \\
\text { etc }\end{array}$ \\
\hline $\begin{array}{l}\text { Order \& } \\
\text { Sequence }\end{array}$ & $\begin{array}{l}\text { the outhor provides } \\
\text { reoders wth } \\
\text { cronologcal events or a } \\
\text { ist of steps in a } \\
\text { procedire }\end{array}$ & & $\begin{array}{l}\text { events n order } \\
\text { of occurrence. } \\
\text { nstructions gver } \\
\text { step-by-step. } \\
\text { order words } \\
\text { frst, next, etc. }\end{array}$ \\
\hline $\begin{array}{l}\text { Problem \& } \\
\text { Solution }\end{array}$ & $\begin{array}{l}\text { the outhor gives } \\
\text { nformation about a } \\
\text { problem and explains one } \\
\text { or more solutions }\end{array}$ & & $\begin{array}{l}\text { a problem is } \\
\text { solved or needs } \\
\text { solving problem, } \\
\text { solution solve }\end{array}$ \\
\hline $\begin{array}{l}\text { Couse \& } \\
\text { Effect }\end{array}$ & $\begin{array}{l}\text { the outhor descrbes an } \\
\text { event or severdl events } \\
\text { (couse) and the events } \\
\text { that follow (effect) }\end{array}$ & & $\begin{array}{l}\text { couse, becouse, } \\
\text { effect, as a } \\
\text { resit of, due to } \\
\text { reason }\end{array}$ \\
\hline
\end{tabular}

\section{Compare and Contrast}

This week we will be focusing on the compare and contrast text structure.

To compare and contrast is show how things are alike or different and can be organized in a Venn Diagram.

You compare and contrast through out the day. For example, you compare and contrast when you pick between two items such as a shirt to wear.

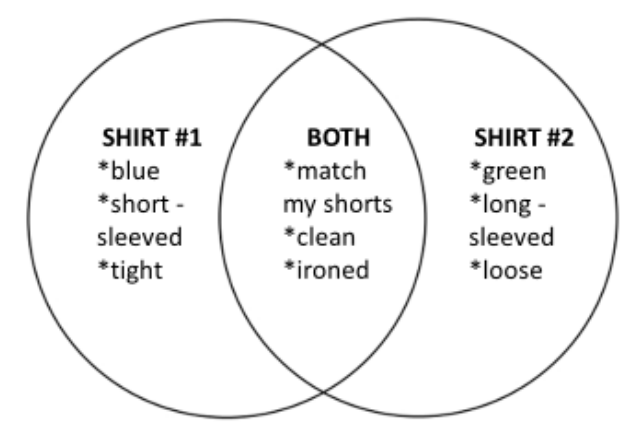




\section{Compare and Contrast}

Compare and Contrast text structures use signal words such as:

Alíke

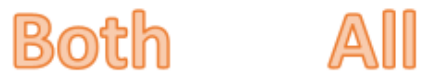

Simimilar

Same

As?

Have in common

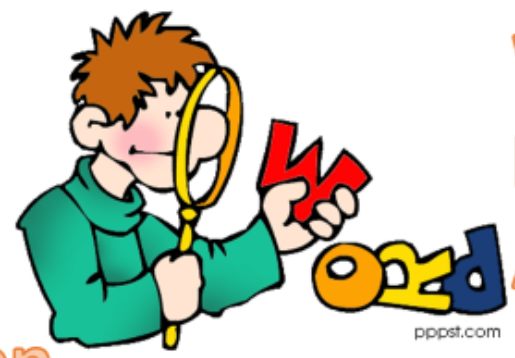

Divferent

Whille

Buts Arthough

\section{Your Turn to Compare and Contrast}

Compare and contrast a toy or game that requires electricity with a toy or game that does not require electricity

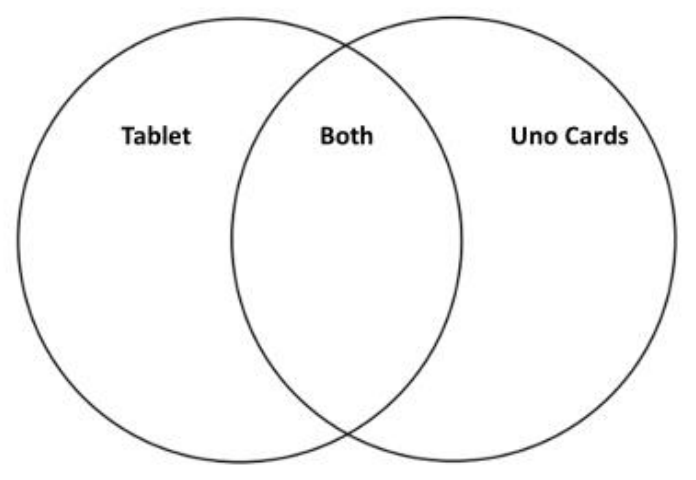




\section{What is Light?}

Let's read a nonfiction science text.

Here are important vocabulary words that we will encounter in the article with their translations. The words with an asterisk $(*)$ are Spanish cognates, meaning the English and Spanish word are similar in spelling.

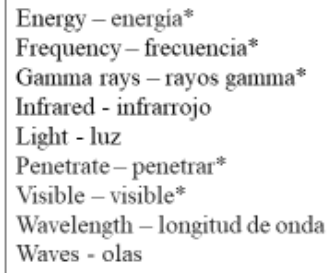

\section{What is Light?}

Now that we have read "What is Light?" let's find some of the key words for compare and contrast in the text.

One way that light travels, including light from the sun, is in the form of waves. All waves carry energy. Scientists can measure how long light waves are. Waves can be different sizes-some are long and some are short.

Long wavelengths have low frequency and are not dangerous, while short wavelengths have high frequency and are dangerous. Long wavelengths carry the least amount of energy, while short wavelengths carry the most energy. The longest wavelength of visible light is seen as red, while the shortest wavelength is violet.

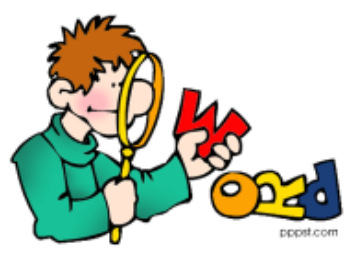




\section{What is Light?}

Now that we have read "What is Light?" let's use the Venn diagram to organize the ideas in the text, specially the section where the author compares and contrast long and short wavelengths.

What is the topic of the text? What is the author explaining?

What details does the author provide about the similarities and differences of long and short wavelengths?

\section{What is Light?}

This is what your Venn diagram should look like:

The information in the Venn diagram helps me understand that the author uses a compare and contrast text structure to explain how the differences between long and short light wavelengths.

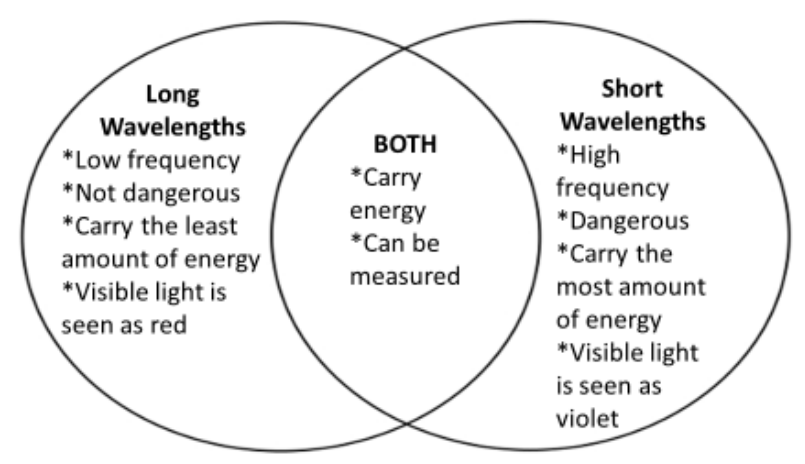

Text Structure: (Description, Sequence, Problem/Solution, Cause \& Effect, Compare/ Contrast)

Main Idea/Key Concept:

\section{Light wavelengths}




\section{What is Light?}

Now we are going to write a summary of what we read by using evidence from the text and the Venn diagram.

Start with the main topic.

Provide a brief summary of the similarities and differences of long and short light wavelengths.

\section{What is Light?}

Here is an example of a summary:

Write using evidence:

Light travels in the form of waves. All waves carry energy and can be measured. Waves differ in many ways. Long wavelengths have low frequency and are not dangerous, while short wavelengths have high frequency and are dangerous. Also, long wavelengths carry the least amount of energy, while the short wavelengths carry the most energy. The longest wavelength is seen as red, while the shortest wavelength is violet. 


\section{Week 5 PowerPoint}

We are going to continue learning about a strategy that can help you better comprehend nonfiction science text. Let's review what a strategy is and what comprehension means.

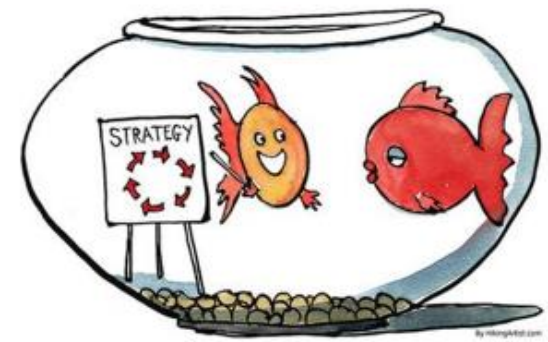

A strategy is something that

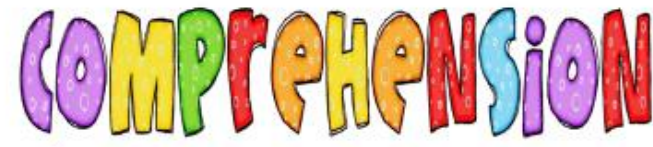
helps you achieve a skill.

Remember, Nonfiction Science Text is text that provides information about science topics.

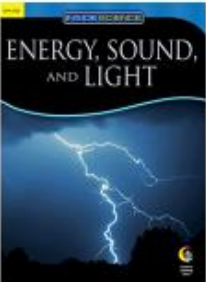

4. From Caterpillar to BUTTERFLY

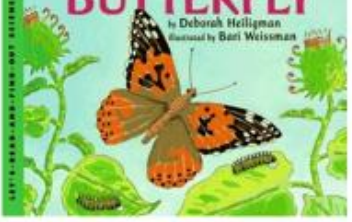

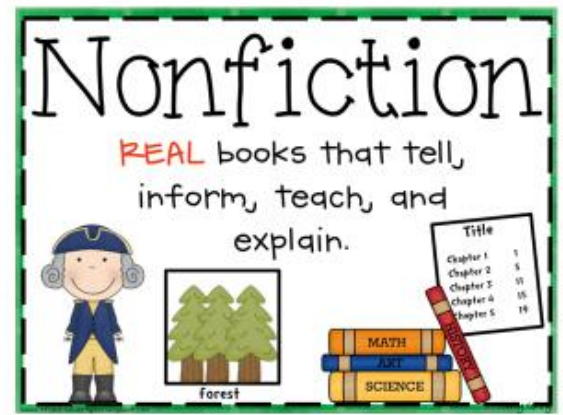

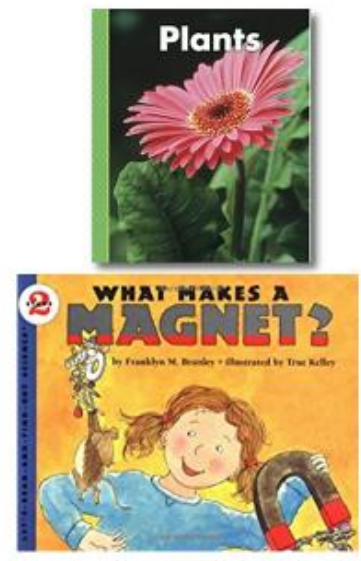


Remember that the strategy we are learning about is understanding text structure to better comprehend.

Remember, Text Structure is how the author organizes the text to help the reader better understand the text.

We have focused on Description, Compare \& Contrast, Sequence, and Cause \& Effect.

\begin{tabular}{|c|c|c|c|}
\hline Structure & Definition & Visual & Clues \\
\hline ption & $\begin{array}{l}\text { the outhor provides } \\
\text { severdl detals of } \\
\text { something to gve the } \\
\text { reader a mental picture }\end{array}$ & & $\begin{array}{c}\text { many adectives } \\
\text { charocteristics } \\
\text { or exomples }\end{array}$ \\
\hline $\begin{array}{l}\text { Compare \& } \\
\text { Contrast }\end{array}$ & $\begin{array}{l}\text { the author dscusses } \\
\text { smicrites and dfferences } \\
\text { between people, things. } \\
\text { concepts, or ideas }\end{array}$ & & $\begin{array}{c}\text { Ikenesses and } \\
\text { dfferences are } \\
\text { dscoussed also, } \\
\text { both n contrast } \\
\text { etc }\end{array}$ \\
\hline $\begin{array}{l}\text { Order \& } \\
\text { Sequence }\end{array}$ & $\begin{array}{l}\text { the author provides } \\
\text { reoders with } \\
\text { ctronoogcal events or a } \\
\text { ist of steps in a } \\
\text { procedure }\end{array}$ & & $\begin{array}{l}\text { events n order } \\
\text { of occurrence. } \\
\text { nstructors gver } \\
\text { step-by-step. } \\
\text { order words } \\
\text { frst, next, etc }\end{array}$ \\
\hline $\begin{array}{c}\text { Problem \& } \\
\text { Solution }\end{array}$ & $\begin{array}{l}\text { the outhor gives } \\
\text { nformation about a } \\
\text { problem and explans one } \\
\text { or more solutions }\end{array}$ & & $\begin{array}{l}\text { a problem is } \\
\text { solved or needs } \\
\text { solving prodiem } \\
\text { solition solve }\end{array}$ \\
\hline $\begin{array}{l}\text { Couse \& } \\
\text { Effect }\end{array}$ & $\begin{array}{l}\text { the author descrbes an } \\
\text { event or severd events } \\
\text { (couse) ond the events } \\
\text { that follow (effect) }\end{array}$ & & $\begin{array}{c}\text { couse, becouse. } \\
\text { effect, os a } \\
\text { resut of, due to } \\
\text { reoson }\end{array}$ \\
\hline
\end{tabular}

\section{Problem and Solution}

This week we will be focusing on the problem and solution text structure.

A problem and solution text describes a problem or issue and then gives one or more solutions and can be organized in a flow chart.

You may experience problems and solutions through out the day. For example, your parents may have a flat tire and cannot take you to school. Your parents solve the problem by putting on the spare tire.

\begin{tabular}{|l|l|}
\hline $\begin{array}{l}\text { My parents have } \\
\text { a flat tire and } \\
\text { cannot take me } \\
\text { to school. }\end{array}$ & $\begin{array}{l}\text { My parents put } \\
\text { on the spare tire } \\
\text { and get me to } \\
\text { school. }\end{array}$ \\
\hline Problem & Solution \\
\hline
\end{tabular}




\section{Problem and Solution}

Problem and Solution text structures use signal words such as:

Problem

Unfortunately

Issue

consequently

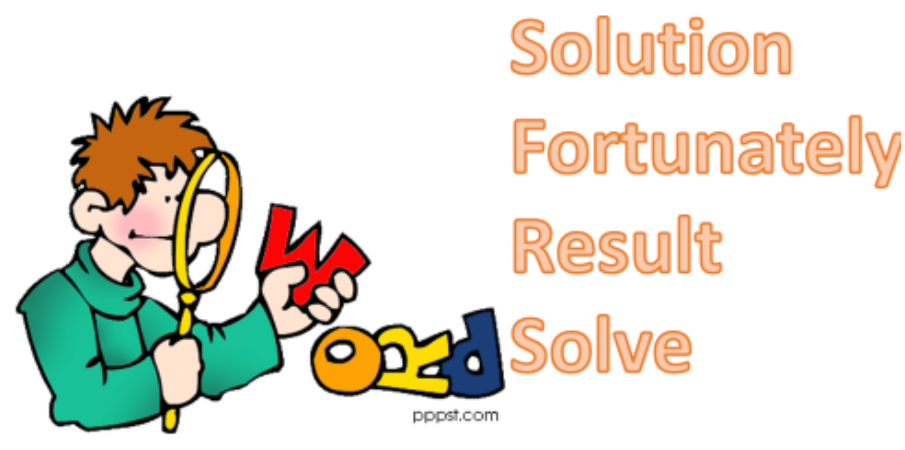

Your Turn to describe a problem and solution Describe a problem you had on a day off from school and how the problem solved.

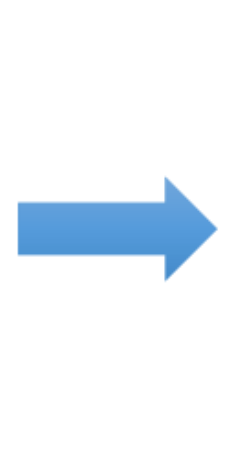

Solution 


\section{Energy for Life}

Let's read a nonfiction science text.

Here are important vocabulary words that we will encounter in the article

with their translations. The words with an asterisk $\left({ }^{*}\right)$ are Spanish

cognates, meaning the English and Spanish word are similar in spelling.

Energy - energía*

Fossil fuels - combustibles fósiles

Natural - natural*

Renewable - renovable

Resources - recursos

Solar energy - energía solar*

\section{Energy for Life}

Now that we have read "Energy for Life" let's find some of the key words for the problem and solution

in the text.

Fuels like natural gas, oil and coal are important natural resources. They are known as fossil fuels and take millions of years to form. We've used them for hundreds of years, and they've powered everything from planes and trains to cars and computers. Unfortunately, the problem with fossil fuels is that they are non-renewable forms of energy. Our power plants burn them faster than nature makes them, and when they are burned, power plants create pollution harmful to the environment.

Fortunately, there are forms of renewable energy out there that help solve the problems that relate to using fossil fuels. They also come from nature and don't harm the environment as much as fossil fuels. Furthermore, we can use them again and again. One form of renewable energy is solar energy. Solar energy uses solar panels, which collect sunlight and convert it into electricity.

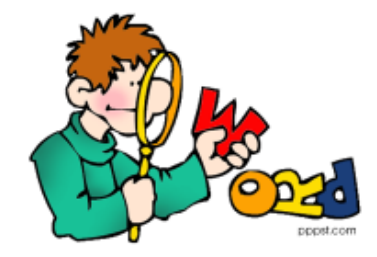

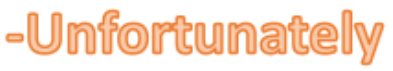

-Problem

-Fortunately

-Solve

-Problens 


\section{Energy for Life}

Now that we have read "Energy for Life" let's use the flow chart to

organize the ideas in the text.

What is the topic of the text? What is the author describing?

What details does the author provide about the problem and solutions?

\section{Energy for Life}

This is what your flow chart should look like:

The information in the flow chart helps me understand that

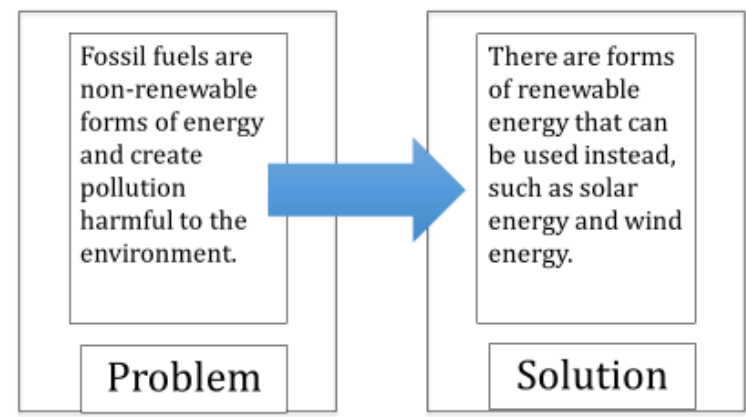
the author uses a problem and solution text structure to describe the problems with nonrenewable resources.

Text Structure: (Description, Sequence Problem/Solution, Cause \& Effect, Compare/ Contrast)

Main Idea/Key Concept:

Non-renewable and renewable energy 


\section{Energy for Life}

Now we are going to write a summary of what we read by using evidence from the text and the flow chart.

Start with the main topic.

Provide a brief summary of the problem and solution described.

\section{Energy for Life}

Here is an example of a summary:

Write using evidence:

We use fossil fuels as an energy source. Unfortunately, fossil fuels are non-renewable forms of energy and create pollution harmful to the environment. One way to help solve this problem is to use non-renewable energy, such as solar energy and wind energy. 


\section{APPENDIX D}

\section{Reciprocal Mapping Templates}

Reciprocal Mapping Template: Description

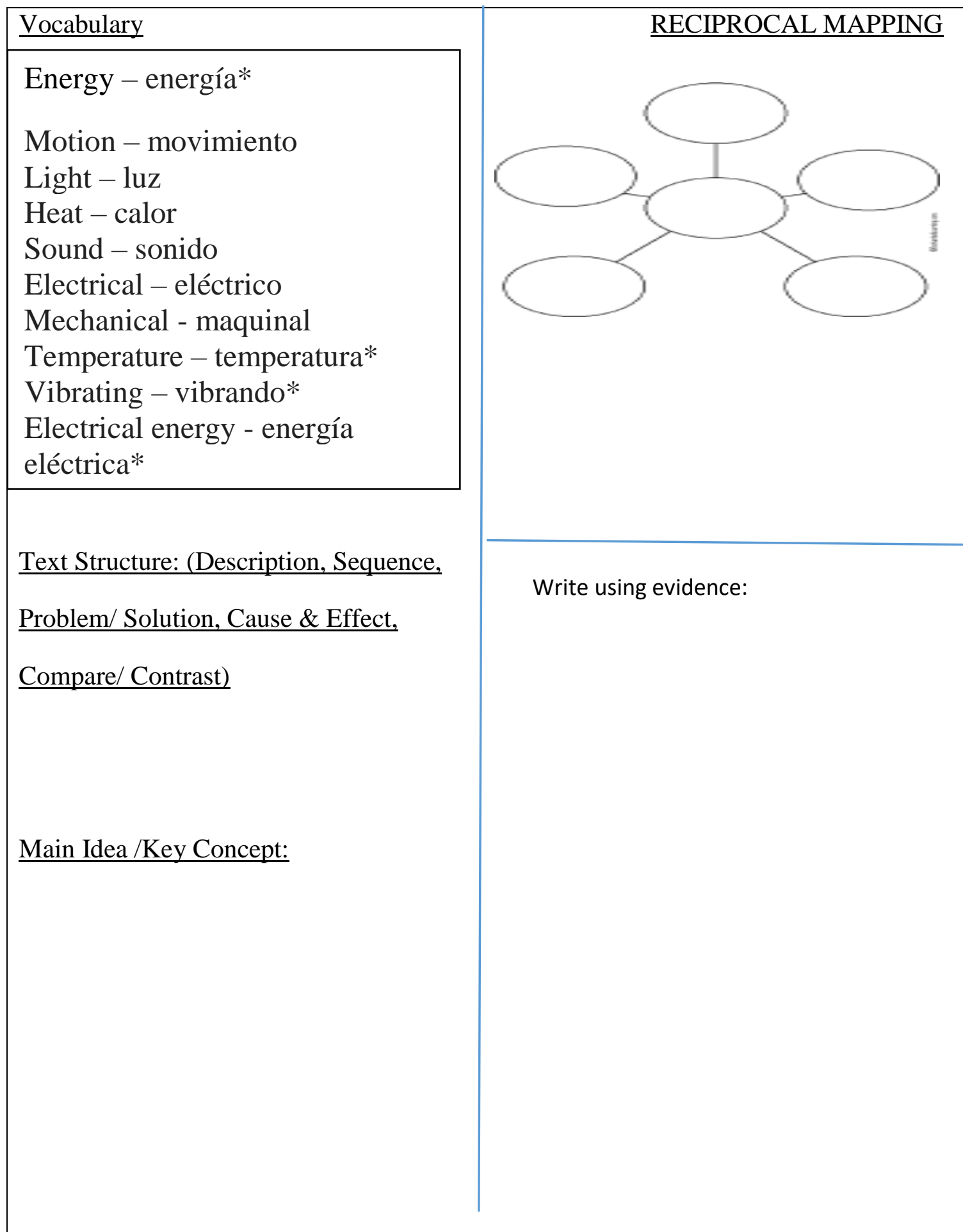


Reciprocal Mapping Template: Sequence

\begin{tabular}{|l|l|}
\hline Vocabulary & \\
Bounce - rebotar & \\
Energy - energía* & \\
Objects - objetos* & \\
Opaque - opaco* & \\
Path - camino \\
Produce - producir* \\
Reflection - reflexión* \\
See- mirar \\
Straight - derecho \\
Transmit - transmitir* \\
Transparent - transparente \\
Vibrating - vibrando* \\
Waves - ondas
\end{tabular}


Reciprocal Mapping Template: Cause and Effect

\begin{tabular}{|l|l|}
\hline Vocabulary & \\
Conduction - conducción* \\
Convection - convección* \\
Electromagnetic - electromagnético* \\
Energy - energía* \\
Heat - calor \\
Melt - derretir \\
Objects - objectos* \\
Radiation - radiación* \\
Systems - sistemas* \\
Temperature - temperatura* \\
Thermometer - termómetro* \\
Transfer - transferir* \\
Waves - olas
\end{tabular}


Reciprocal Mapping Template: Compare and Contrast

\begin{tabular}{|l|l|}
\hline Vocabulary & \\
\hline Energy - energía* \\
Frequency - frecuencia* \\
Gamma rays - rayos gamma* \\
Infrared - infrarrojo \\
Light - luz \\
Penetrate - penetrar* \\
Visible - visible* \\
Wavelength - longitud de onda \\
Waves - olas
\end{tabular}


Reciprocal Mapping Template: Problem Solution

\begin{tabular}{|l||l|}
\hline Vocabulary & \\
\hline $\begin{array}{l}\text { Energy - energía* } \\
\text { Fossil fuels - combustibles fósiles } \\
\text { Natural - natural* } \\
\text { Renewable - renovable } \\
\text { Resources - recursos } \\
\text { Solar energy - energía solar* }\end{array}$ & \\
\hline & \\
\hline Text Structure: (Description, Sequence, & \\
\hline Problem/ Solution, Cause \& Effect, & Solution \\
\hline Compare/ Contrast) & Problem \\
\hline & \\
\hline & \\
\hline
\end{tabular}


VITA

\section{OLGA ELENA FLAMION}

Born, Puerto Cabezas, Nicaragua

1997

Early Childhood Education Student Award

G. Holmes Braddock Senior High

Miami, Florida

2001

B.S., Elementary Education

Barry University

Miami Shores, Florida

2001-2003

Teacher

Collier County Public Schools

Naples, Florida

2003-2005

Teacher

Miami-Dade County Public Schools

Miami, Florida

2005-2008

Reading Coach

Miami-Dade County Public Schools

Miami, Florida

2007

M.S., Reading Education and Special Education

University of Miami

Coral Gables, Florida

2008

2008 Francisco R. Walker Teacher of the Year Award Poinciana Park Elementary School

Miami, Florida

2008-Current

Teacher

Miami-Dade County Public Schools

Miami, Florida

2012

Lorraine R. Gay Award for Excellence in

Research/Scholarship

Florida International University

Miami, Florida

2014-Current

Adjunct Professor

Florida International University

Miami, Florida 
Doctoral Candidate

Florida International University

Miami, Florida

\section{PUBLICATIONS AND PRESENTATIONS}

Labadie, A. L., Lieberman, I. J., Vargo, K., \& Flamion, O. (2012). The use of literature to combat bullying. Paper presented at The $11^{\text {th }}$ Annual College of Education and Graduate Student Network Research Conference, Florida International University, Miami, Florida.

Davis, M., Flamion, O., \& Fine, J.C. (2012). Teachers' instructional time in reading and material usage. American Reading Forum: Yearbook. Vol. 32. 